EGG--2208

DE83 014808

\title{
DISCLAIMER
}

This report was prepared as an account of work sponsored by an agency of the United States Government. Neither the United States Government nor any agency thereof, nor any of their employees, makes any warranty, express or implied, or assumes any legal liability or responsibility for the accuracy, completeness, or usefulness of any information, apparatus, product, or process disclosed, or represents that its use would not infringe privately owned rights. Reference herein to any specific commercial product, process, or service by trade name, trademark, manufacturer, or otherwise does not necessarily constitute or imply its endorsement, recommendation, or favoring by the United States Government or any agency thereof. The views and opinions of authors expressed herein do not necessarily state or reflect those of the United States Government or any agency thereof.

\section{RAFT RIVER BINARY-CYCLE GEOTHERMAL PILOT POWER PLANT FINAL REPORT}

\author{
Carl J. Bliem
}

Larry F. Walrath

Published April 1983

EG\&G Idaho, Inc.

Idaho Falls, Idaho 83415

\section{PORTIONS OF THIS REPORT ARE ILLEGIBLE. \\ It has been reproduced from the best avallable copy to permit the broadest possible availability.}

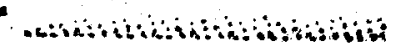

Prepared for the

U.S. Department of Energy

Idaho Operations Office

Under DOE Contract No. DE-AC07-76ID01570 


\section{DISCLAIMER}

This report was prepared as an account of work sponsored by an agency of the United States Government. Neither the United States Government nor any agency Thereof, nor any of their employees, makes any warranty, express or implied, or assumes any legal liability or responsibility for the accuracy, completeness, or usefulness of any information, apparatus, product, or process disclosed, or represents that its use would not infringe privately owned rights. Reference herein to any specific commercial product, process, or service by trade name, trademark, manufacturer, or otherwise does not necessarily constitute or imply its endorsement, recommendation, or favoring by the United States Government or any agency thereof. The views and opinions of authors expressed herein do not necessarily state or reflect those of the United States Government or any agency thereof. 


\section{DISCLAIMER}

Portions of this document may be illegible in electronic image products. Images are produced from the best available original document. 


\begin{abstract}
The design and performance of a 5-MW(e) binary-cycle pilot power plant that used a moderate-temperature hydrothermal resource, with isobutane as a working fluid, are examined. Operating problems experienced and solutions found are discussed and recommendations are made for improvements to future power plant designs. The plant and individual systems are analyzed for design specification versus actual performance figures.
\end{abstract}

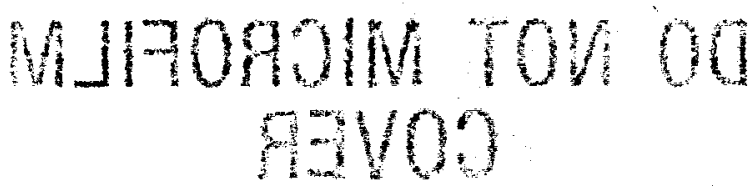




\section{SUMMARY}

The design, construction, and operation of a binary-cycle pilot power plant, rated at $5 \mathrm{MW}(\mathrm{e})$, in the Raft River Valley of Southern Idaho constituted a major part of the geothermal program effort conducted at the Idaho National Engineering Laboratory for the U.S. Department of Energy. The plant was built to demonstrate the technical feasibility of generating electric power from a moderate-temperature geothermal resource, using state-of-the-art components and isobutane as the working fluid. Although the plant was used on a fairly low-temperature resource, the experience gained was valuable for any binary cycle plant. The plant was designed to take full advantage of the relatively large increases in power that can be produced using organic Rankine cycles when ambient temperatures fall below the summer design point. Treated geothermal water was used for makeup in the wet cooling tower.

The plant, built for approximately $\$ 13$ million, contained sufficient instrumentation and data acquisition equipment to obtain accurate performance data. Originally, the plant was to run for five years of testing and operational evaluation, with numerous tests after initial startup, periodic tests during the operating period, and numerous tests before plant shutdown. Plant operations were first cut back to three years and then further trimmed to startup and shakedown run in the fall of 1981, a performance test sequence in the spring of 1982, and a final shutdown June 15, 1982.

The pilot power plant used a two-stage boiling cycle. This process delivered high performance without the use of a supercritical cycle, which was deemed undesirable because of its expected sensitivity of operation and performance to changes in reservoir temperature at a time when reservoir temperature was not well known. Liquid isobutane was piped into a low-temperature preheater, where it received energy from the geofluid. The flow was split after the preheater so that about one-third flowed into a low-pressure boiler and two-thirds passed into the shell side of the high-temperature preheater for additional heating by the geofluid before entering the high- pressure boiler. Isobutane vapors from the lowand high-pressure boilers were fed through appropriate inlets to turbine stages. The turbine drove a generator that was connected to an electrical distribution system.

The supply and injection system for the pilot plant included seven wells within a four-squaremile tract of the Raft River Known Geothermal Resource Area. Four wells supplied hot geothermal water, two were injection wells, and one an experimental well.

Both submersible and line-shaft pumps were used on the Raft River wells. The submersible pumps were replaced by line-shaft pumps because the existing submersible pump systems were found to be unreliable for long term operation. Cementasbestos pipe, used for supply and injection system lines, proved unsatisfactory because of ruptures and leaks when the system experienced thermal shock or water hammer.

For the reduced testing program, a test matrix was run that included the following categories: baseline, geofluid temperature sensitivity, geofluid flow sensitivity, coolant temperature sensitivity, and coolant flow sensitivity. Analyses on the plant and individual components were made after plant shutdown and showed that the system performance, after correction for belowspecification component performance, was approximately as predicted.

Overall, the plant operated very smoothly as a system under steady-state conditions with no operator intervention. Generally, operational problems encountered were minor and could have been corrected by procedural changes had the plant been operated over a longer period. A problem of excessive liquid carryover from the boilers was corrected during testing to a substantial extent, for example, by operating at boiler liquid levels below the design values. A binary power plant is technically viable for production of power from a moderate-temperature geothermal resource. The dual-boiling characteristic of the plant offers no problems for operability and is predictable. 


\section{ACKNOWLEDGMENTS}

Many persons at the Department of Energy and EG\&G Idaho, Inc., contributed to the success of this project. While it is impossible to list everyone who worked on this project, recognition of certain individuals is appropriate.

First, the persons who were primarily responsible for the conceptual work and the early development of the project: for the Department of Energy, John L. Griffith, Martin R. Scheve, and Wayne R. Knowles; for EG\&G Idaho, Inc., Jay F. Kunze, Richard L. Miller, Gregory L. Mines, Robert H. Dart, Lowell G. Miller, Warren W. Madsen, Roger R. Piscitella, and Judson F. Whitbeck.

Second, Denis J. Feck, the DOE Program Manager, Russell D. Lease, the DOE Site Manager, and the Raft River Operations Staff, under Norman W. Spang, who performed an exceptional job of test planning and startup operations. The first time that the system was started it was taken to full thermal power.

The other contributors to this final report include: Edward S. Brown, O. Jack Demuth, Edward G. DiBello, Keith S. Fullmer, Robert S. Hope, Robert J. Kochan, Kenneth H. Liebelt, Raymond D. Sanders, Howard M. Stromberg, Daniel F. Suciu, Judson F. Whitbeck, Deborah J. Wiggins, Penny M. Wikoff, and Dennis R. Wilkenson. 


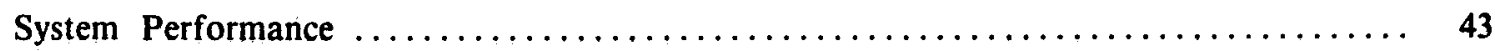

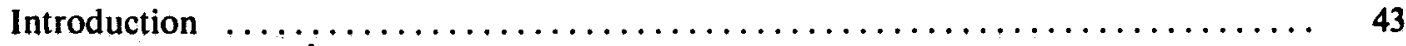

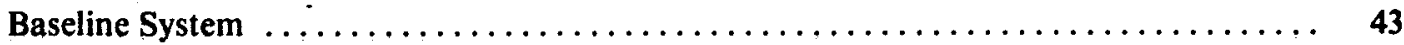

Sensitivity Studies $\ldots \ldots \ldots \ldots \ldots \ldots \ldots \ldots \ldots \ldots \ldots \ldots \ldots \ldots \ldots \ldots \ldots \ldots \ldots \ldots$

System Transients $\ldots \ldots \ldots \ldots \ldots \ldots \ldots \ldots \ldots \ldots \ldots \ldots \ldots \ldots \ldots \ldots \ldots \ldots \ldots \ldots \ldots \ldots .48$

Plant Output with Specified Component Performance $\ldots \ldots \ldots \ldots \ldots \ldots \ldots \ldots \ldots \ldots$

Performance Analysis Conclusions $\ldots \ldots \ldots \ldots \ldots \ldots \ldots \ldots \ldots \ldots \ldots \ldots \ldots \ldots \ldots$

PLANT OPERATION $\ldots \ldots \ldots \ldots \ldots \ldots \ldots \ldots \ldots \ldots \ldots \ldots \ldots \ldots \ldots \ldots \ldots \ldots \ldots \ldots, \quad 53$

Operation of Primary Systems $\ldots \ldots \ldots \ldots \ldots \ldots \ldots \ldots \ldots \ldots \ldots \ldots \ldots \ldots \ldots \ldots \ldots \ldots \ldots$

System Fill $\ldots \ldots \ldots \ldots \ldots \ldots \ldots \ldots \ldots \ldots \ldots \ldots \ldots \ldots \ldots \ldots \ldots \ldots \ldots \ldots \ldots \ldots \ldots \ldots \ldots$

Plant Startup $\ldots \ldots \ldots \ldots \ldots \ldots \ldots \ldots \ldots \ldots \ldots \ldots \ldots \ldots \ldots \ldots \ldots \ldots \ldots \ldots \ldots \ldots \ldots \ldots \ldots, 53$

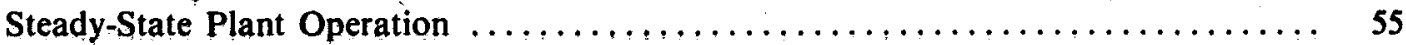

Plant Shutdown $\ldots \ldots \ldots \ldots \ldots \ldots \ldots \ldots \ldots \ldots \ldots \ldots \ldots \ldots \ldots \ldots \ldots \ldots \ldots \ldots$

Operation of Auxiliary Plant Systems $\ldots \ldots \ldots \ldots \ldots \ldots \ldots \ldots \ldots \ldots \ldots \ldots \ldots \ldots \ldots \ldots, \quad 56$

Water Treatment System $\ldots \ldots \ldots \ldots \ldots \ldots, \ldots \ldots \ldots \ldots \ldots \ldots \ldots \ldots \ldots \ldots \ldots \ldots \ldots \ldots$

Instrumentation and Data Transmittal System $\ldots \ldots \ldots \ldots \ldots \ldots \ldots \ldots \ldots \ldots \ldots \ldots \ldots$

Firewater System $\ldots \ldots \ldots \ldots \ldots \ldots \ldots \ldots \ldots \ldots \ldots \ldots \ldots \ldots \ldots \ldots \ldots \ldots \ldots \ldots \ldots$

Instrument Air and Nitrogen System $\ldots \ldots \ldots \ldots \ldots \ldots \ldots \ldots, \ldots \ldots \ldots \ldots \ldots \ldots \ldots$

Flare System $\ldots \ldots \ldots \ldots \ldots \ldots \ldots \ldots \ldots \ldots \ldots \ldots \ldots \ldots \ldots \ldots \ldots \ldots \ldots \ldots \ldots \ldots \ldots \ldots \ldots, 60$

Supply and Injection System Operations $\ldots \ldots \ldots \ldots \ldots \ldots \ldots \ldots \ldots \ldots$

Production Pumps $\ldots \ldots \ldots \ldots, \ldots \ldots \ldots \ldots \ldots \ldots \ldots \ldots \ldots \ldots \ldots \ldots \ldots \ldots \ldots \ldots \ldots \ldots \ldots, 61$

Injection Pumps $\ldots \ldots \ldots \ldots \ldots \ldots \ldots \ldots \ldots \ldots \ldots \ldots \ldots \ldots \ldots \ldots \ldots \ldots \ldots \ldots \ldots \ldots \ldots, 62$

Cement-Asbestos Piping,$\ldots \ldots \ldots \ldots \ldots \ldots \ldots \ldots \ldots \ldots \ldots \ldots \ldots \ldots \ldots \ldots \ldots \ldots$

System Performance $, \ldots, \ldots \ldots \ldots \ldots \ldots, \ldots \ldots \ldots \ldots \ldots \ldots \ldots \ldots \ldots \ldots \ldots \ldots \ldots, \ldots 4$

CONCLUSIONS AND RECOMMENDATIONS $\ldots \ldots \ldots \ldots \ldots \ldots \ldots \ldots \ldots \ldots \ldots$

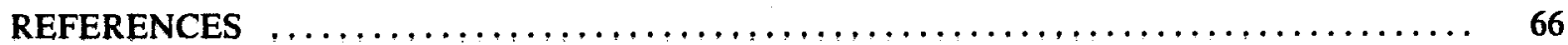

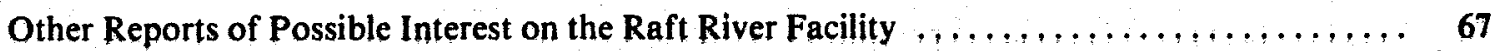

APPENDIX A-PLANT PIPING AND INSTRUMENTATION SCHEMATIC DRAWINGS . , . 69

\section{FIGURES}

1. Simplified schematic diagram of the $5-M W(e)$ pilot geothermal power plant $\ldots \ldots, \ldots, \ldots, \quad 5$

2. Raft River geothermal site $, \ldots \ldots \ldots \ldots, \ldots, \ldots, \ldots, \ldots, \ldots, \ldots, \ldots, \ldots, \ldots \ldots \ldots, 7$.

3. An aerial view of the 5-MW(e) pilot plant facility. Top right: control, office, and laboratory building and maintenance building. Lower right: cooling tower and adjoining water treatment building. Left: process area, hydrocarbon storage, and nitrogen tanks 


\section{CONTENTS}

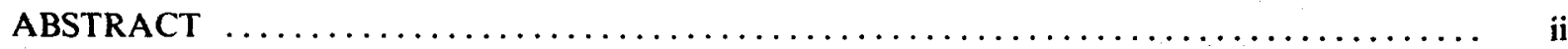

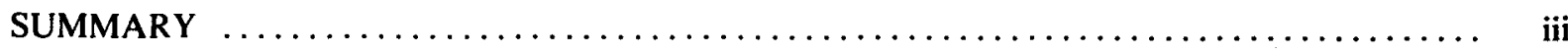

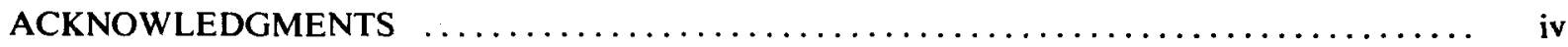

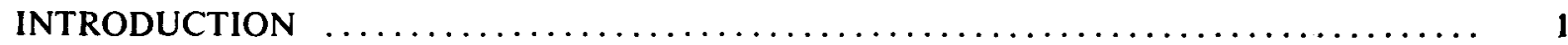

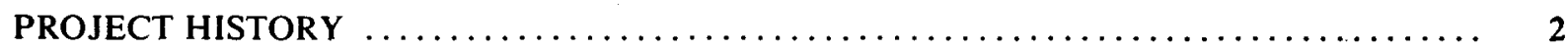

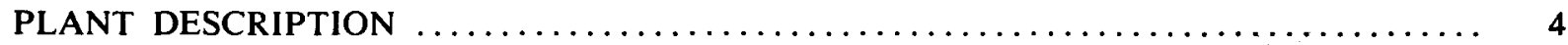

Power Cycle Selection and Description $\ldots \ldots \ldots \ldots \ldots \ldots \ldots \ldots \ldots \ldots \ldots \ldots \ldots \ldots \ldots \ldots \ldots \ldots \ldots$

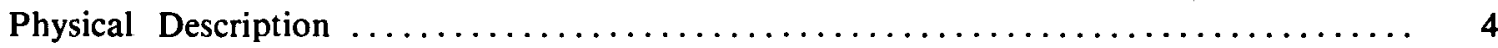

Component Descriptions $\ldots \ldots \ldots \ldots \ldots \ldots \ldots \ldots \ldots \ldots \ldots \ldots \ldots \ldots \ldots \ldots \ldots \ldots \ldots \ldots \ldots \ldots$

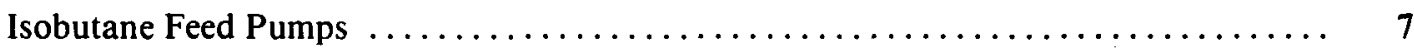

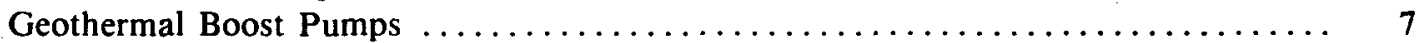

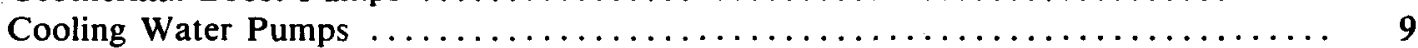

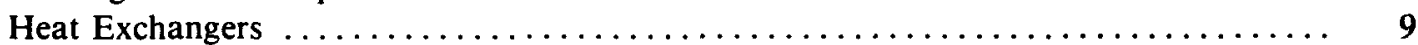

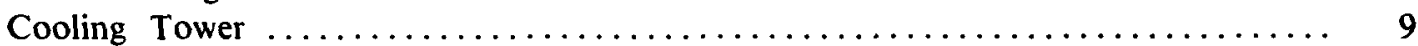

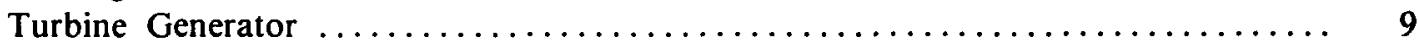

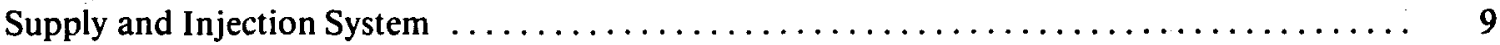

System Control Description $\ldots \ldots \ldots \ldots \ldots \ldots \ldots \ldots \ldots \ldots \ldots \ldots \ldots \ldots \ldots \ldots \ldots \ldots \ldots \ldots \ldots \ldots$

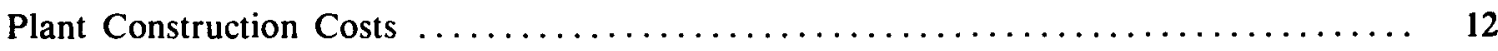

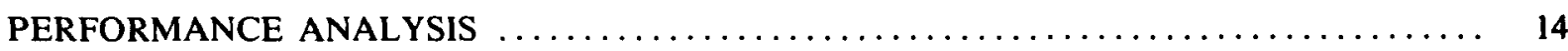

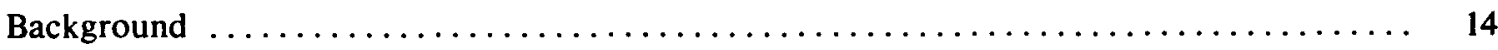

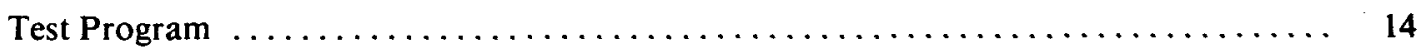

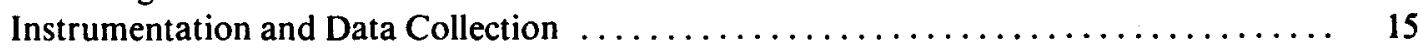

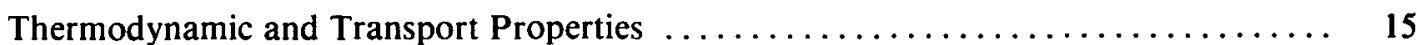

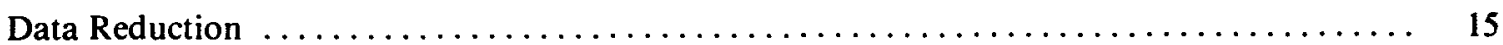

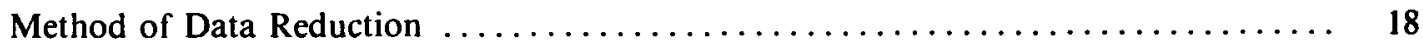

Boiler Level-Liquid Entrainment Test $\ldots \ldots \ldots \ldots \ldots \ldots \ldots \ldots \ldots \ldots \ldots \ldots, \quad 20$

Assessment of Data Consistency $\ldots \ldots \ldots \ldots \ldots \ldots \ldots \ldots \ldots \ldots \ldots \ldots \ldots \ldots \ldots \ldots, 21$

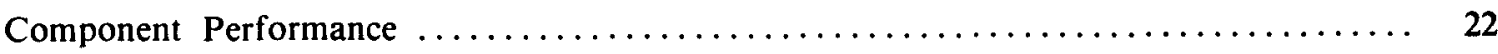

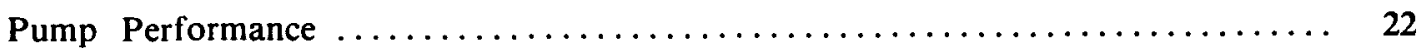

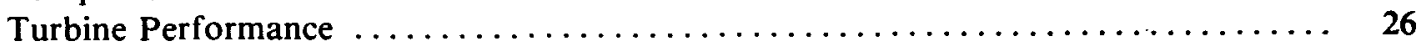

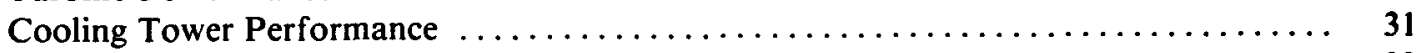

Heat Exchanger Performance $\ldots \ldots \ldots \ldots \ldots \ldots \ldots \ldots \ldots \ldots \ldots \ldots \ldots \ldots \ldots \ldots \ldots \ldots, \quad 32$ 
4. The Raft River 5-MW(e) pilot plant process area. Right: low-pressure preheater (lower) and low-pressure boiler (upper). Center: high-pressure preheater (lower) and high-pressure boiler (upper). Left: condenser (upper) and condensate receiver (lower). Extreme left: generator (upper) and oil system (lower)

5. Schematic diagram of the control system for the 5-MW(e) pilot geothermal power plant $\ldots \ldots \quad 10$

6. Instrumentation in the isobutane system $\ldots \ldots \ldots \ldots \ldots \ldots \ldots \ldots \ldots \ldots \ldots \ldots \ldots \ldots$

7. Instrumentation in the geofluid system $\ldots \ldots \ldots \ldots \ldots \ldots \ldots \ldots \ldots \ldots \ldots \ldots \ldots \ldots \ldots \ldots \ldots$

8. Instrumentation in the cooling water system $\ldots \ldots \ldots \ldots \ldots \ldots \ldots \ldots \ldots \ldots \ldots \ldots \ldots \ldots$

9. Detailed schematic diagram of the 5-MW(e) pilot geothermal power plant $\ldots \ldots \ldots \ldots \ldots \ldots$

10. Low-pressure boiler entrainment tests $\ldots \ldots \ldots \ldots \ldots \ldots \ldots \ldots \ldots \ldots \ldots \ldots \ldots \ldots \ldots$

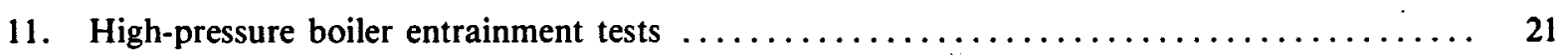

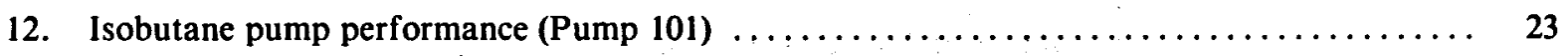

13. Isobutane pump performance (Pump 102) $\ldots \ldots \ldots \ldots \ldots \ldots \ldots \ldots \ldots \ldots \ldots \ldots \ldots \ldots \ldots \ldots \ldots \ldots$

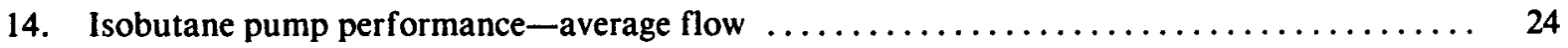

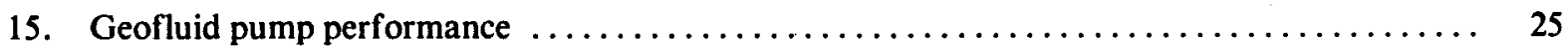

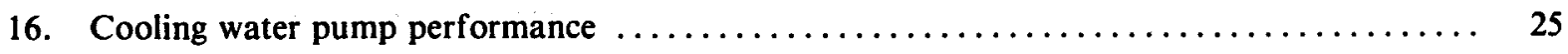

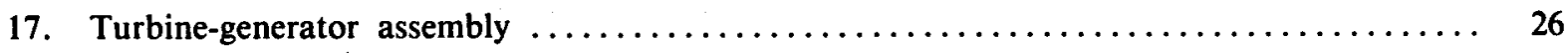

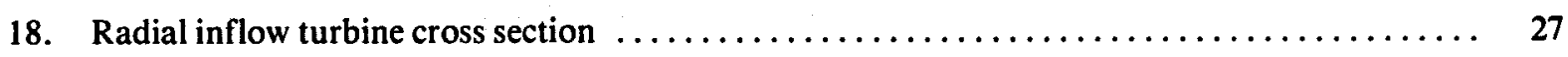

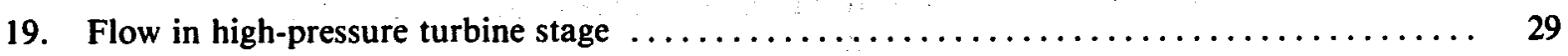

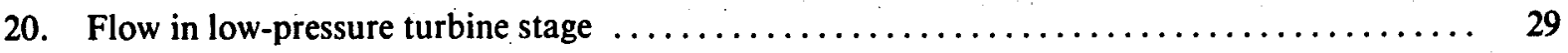

21. Calculated throat area for high-pressure turbine stage $\ldots \ldots \ldots \ldots \ldots \ldots \ldots \ldots \ldots \ldots \ldots, 30$

22. Calculated throat area for low-pressure turbine stage $\ldots \ldots \ldots \ldots \ldots \ldots \ldots \ldots \ldots \ldots \ldots, 31$

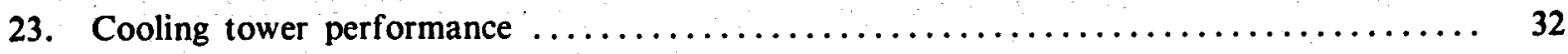

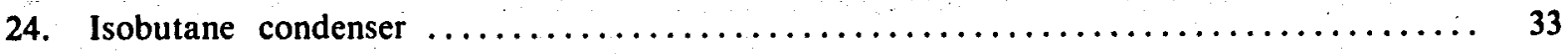

25. Measured heat exchanger performance relative to manufacturer's design $\ldots \ldots \ldots \ldots \ldots \ldots$

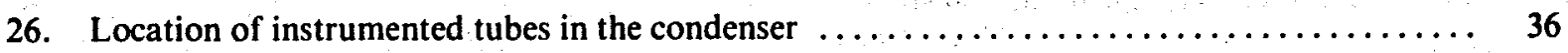

27. Comparison of measured and calculated condenser tube temperatures-Test $1 \mathrm{~A} \ldots \ldots \ldots .37$

28. Comparison of measured and calculated condenser tube temperatures-Test 1 BTL $\ldots \ldots \ldots 37$

29. Comparison of measured and calculated condenser tube temperatures-Test 7AR $\ldots \ldots \ldots 38$ 
30. Low-temperature preheater configuration $\ldots \ldots \ldots \ldots \ldots \ldots \ldots \ldots \ldots \ldots \ldots \ldots \ldots \ldots$

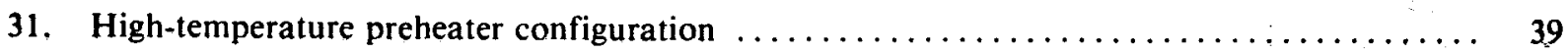

32. Low-pressure preheater measured fluid temperature-Test $1 \mathrm{~A} \ldots \ldots \ldots \ldots \ldots \ldots \ldots \ldots$

33. High- and low-pressure boiler configurations $\ldots \ldots \ldots \ldots \ldots \ldots \ldots \ldots \ldots \ldots \ldots \ldots \ldots$

34. Loss of availability through system, calculated for Test $1 \mathrm{~A} \ldots \ldots \ldots \ldots \ldots \ldots \ldots \ldots$

35. Sensitivity of turbine output to changes in geofluid temperature $\ldots \ldots \ldots \ldots \ldots \ldots \ldots \ldots$

36. Sensitivity of generator output to geofluid flow rate $\ldots \ldots \ldots \ldots \ldots \ldots \ldots \ldots \ldots \ldots$

37. Sensitivity of generator output to cooling water inlet temperature $\ldots \ldots \ldots \ldots \ldots \ldots \ldots$

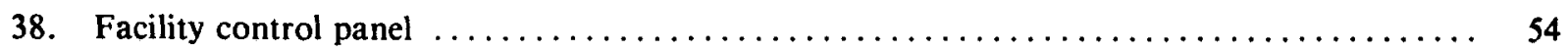

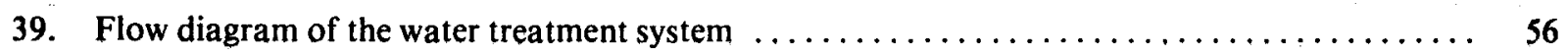

40. Pipelines for geofluid fluid supply and injection system $\ldots \ldots \ldots \ldots \ldots \ldots \ldots \ldots \ldots \ldots$

\section{TABLES}

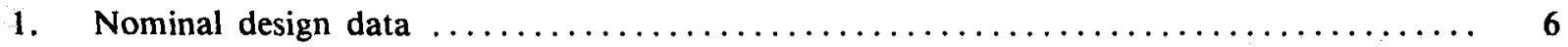

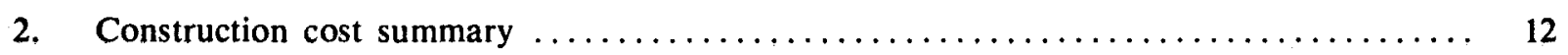

3. Component material cost summary $\ldots \ldots \ldots \ldots \ldots \ldots \ldots \ldots \ldots \ldots \ldots \ldots \ldots \ldots \ldots$

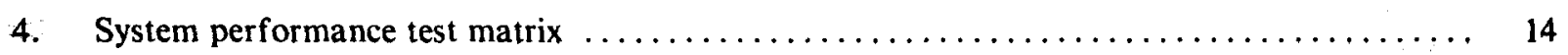

5. Closure of mass and energy balance as percentage of average value $\ldots \ldots \ldots \ldots \ldots \ldots \ldots 22$

6. Calculated power from test data $\ldots \ldots \ldots \ldots \ldots \ldots \ldots \ldots \ldots \ldots \ldots \ldots \ldots \ldots \ldots \ldots \ldots \ldots, 28$

7. Calculated state point properties for Test $1 \mathrm{~A}$ (typical computer output) $\ldots \ldots \ldots \ldots \ldots \ldots 44$

8. Baseline performance of system as specified (Test $1 \mathrm{~A}) \ldots \ldots \ldots \ldots \ldots \ldots \ldots \ldots \ldots \ldots \ldots$

9. Condenser cleaning and passivating procedure $\ldots \ldots \ldots \ldots \ldots \ldots \ldots \ldots \ldots \ldots \ldots \ldots \ldots \ldots$

10. Nominal chemical composition of makeup water $\ldots \ldots \ldots \ldots \ldots \ldots \ldots \ldots \ldots \ldots \ldots \ldots$

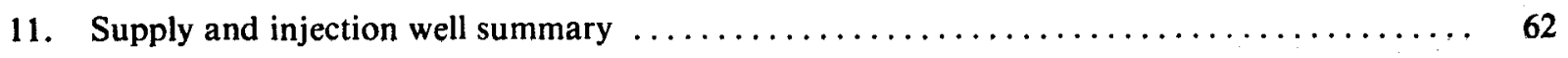

12. Supply and injection system pump history $\ldots \ldots \ldots \ldots \ldots \ldots \ldots \ldots \ldots \ldots \ldots \ldots \ldots \ldots, 63$ 


\section{RAFT RIVER BINARY-CYCLE GEOTHERMAL PILOT POWER PLANT FINAL REPORT}

\section{INTRODUCTION}

Work on geothermal programs at the Idaho National Engineering Laboratory (INEL) has focused on using moderate-temperature hydrothermal resources. A major portion of the work was the design, construction, and operation of a binary-cycle pilot power plant with a nominal gross rating of $5 \mathrm{MW}(\mathrm{e})$, located in the Raft River Valley of Southern Idaho.

The purpose of building this plant was, to demonstrate the technical feasibility of generating electric power from a moderate-temperature hydrothermal resource in an environmentally acceptable manner using a dual-boiling Rankine cycle with isobutane as the working fluid and state-of-the-art components. In operating the plant, its performance would be evaluated and operating experience obtained. The information and general operational experience would be applicable to any binary-cycle plant including geothermal, solar, or waste heat bottoming cycles. In this plant, the isobutane boiled in two stages providing high- and low-temperature streams to a double impeller radial inflow turbine. The plant was designed to take maximum advantage of the low ambient temperatures occurring in the intermountain region by operating in a floating power mode, thereby enabling the plant to produce more power in the winter months than at the summer design condition. It was also designed to use treated geothermal water for plant heat rejection in the wet cooling tower to gain experience for geothermal plants located in environments where water is scarce. The $\$ 13$ million plant contained sufficient instrumentation and data acquisition equipment to obtain accurate performance data, as well as some special instrumentation in the large heat exchangers in order to obtain some detailed performance data. Near the plant are four produc- tion wells used to supply geothermal fluid and two injection wells used to dispose of the spent fluid.

When the project was conceived, the plant was to be run for a five-year period of testing and operational evaluation. Performance tests were to include a comprehensive testing program immediately after initial startup, with some testing through the duration of operations, and an additional comprehensive testing effort at the end of the test program. When the Department of Energy (DOE) shifted its goals from demonstration projects to more basic research, plant operations were first cut back to three years and later to a startup and shakedown run in the fall of 1981, continued shakedown and a sequence of performance tests in the spring of 1982 , and a final shutdown June 15, 1982.

This final report on the power plant is primarily technical, and describes the plant system, presents the project history and problem-solving efforts, covers plant operations experience and testing through the shutdown phase, and analyzes the performance of individual system components. The actual performance of the Rankine thermodynamic cycle power plant is also established and compared with predicted performance. The report does not include economic evaluation of the plant nor detailed information/relative to reservoir performance. Reference 9 and the report by D. W. Allman et al. listed under "Other Reports of Possible Interest" (in the Reference Section) contain reservoir performance information. Detailed economic evaluation was not made here since the plant and geofluid supply system were not designed and constructed in a totally automatic commercial-sized configuration. Some general economic considerations, however, are presented in the paper by J. F. Whitbeck et al., also listed in the Reference Section. 


\section{PROJECT HISTORY}

The INEL has been involved in geothermal energy development since 1973. Since the technical feasibility and development of high-temperature geothermal resources had been demonstrated at The Geysers (California) and elsewhere, the development and uses of the country's more numerous moderate-temperature resources posed many new challenges, especially in the generation of electricity. Successful demonstration of the technical viability of such resources could open a vast resource base to augment the nation's energy supplies. Thus, the INEL's objective has been to study the feasibility of using a moderatetemperature geothermal resource for both electrical production and direct-heat applications.

Earlier efforts by the U.S. Geological Survey (USGS) identified such a moderate-temperature resource near the INEL in the Raft River area of Southern Idaho. This resource had an inferred reservoir temperature of $300^{\circ} \mathrm{F}$, too low for conventional flashed steam applications, but high enough for binary electrical production, as well as for a large number of direct applications. Thus, a joint effort between the Idaho Operations Office of the Atomic Energy Commission (AEC), the USGS, the State of Idaho, the Raft River Rural Electric Cooperative, and the INEL was undertaken to develop this resource.

After additional geologic and geophysical exploration work, a successful well was drilled in February 1975. A second successful well was drilled four months later. Additional exploration, production, and injection wells were drilled between 1975 and 1978, proving the existence of an adequate resource at Raft River. The resource temperatures, however, proved to be somewhat lower than predicted initially (275 to 295 rather than $300^{\circ} \mathrm{F}$ ). Three of these wells were operated as production wells, and two as injection wells in support of the 5-MW(e) pilot plant. A fourth well provided geofluid under artesian flow conditions for pipe warmup.

Initially, a 12-MW(e) direct flash steam plant and a 10-MW(e) binary plant were considered for possible construction at Raft River and preconceptual designs of these systems were made before choosing the 5-MW(e) gross size for a binary pilot power plant in 1976. System optimization analysis showed that the use of a dual-boiler system would increase the geofluid effectiveness ( $\mathrm{W} \mathrm{h} / \mathrm{lbm}$ geofluid) of the system by approximately $20 \%$ compared with a single-boiler system and was better than a flash system by a factor of 2 . The first conceptual design done at the INEL, was for a system designed without a turbine. Valves were to be used to simulate the turbine performance. The 40-MW(e) thermal loop was estimated to cost $\$ 8$ million.

In October 1976, an architect-engineer was selected by the Idaho Operations Office of the Energy Research and Development Administration (ERDA) to do the Title I and II design work. Facility Systems Engineering Corporation of Los Angeles was selected to perform this work. (At the time of its dissolution in January 1975, the responsibilities of the AEC for this program were assumed by ERDA.) Title I design was completed in June 1977 and the design was reviewed by ERDA, EG\&G Idaho, Inc., and Washington Public Power Supply System personnel. Procurement of long-lead time items was initiated at this time with contracts let in July 1977 for the heat exchangers, the isobutane feed pumps, geothermal boost pump, and cooling tower. Title II design was completed in April 1978. The construction bid package was distributed at this time.

As noted, the pilot plant was initially designed to be a thermal loop with valves simulating turbine effects. It was later decided to incorporate a turbine-generator into the system. In January 1978, a consulting firm was hired to prepare the turbine specifications.

A study comparing a radial-inflow-turbine design with an axial flow design revealed no decisive advantages of either design. The radial inflow design was selected by the INEL and DOE on the basis that there was virtually no operating experience with units of this size, whereas the axial flow designs were in common use. The DOE was activated in October 1977, and assumed overall program responsibility. The subcontract for the turbine was awarded in October 1978. The award of architect-engineering work for the facility modification to include the turbine generator was made by DOE to Burns and Roe Pacific, Inc., in March 1979.

During this period, several parallel efforts were conducted to support the plant design. Corrosion 
and heat exchanger fouling tests were conducted during 1976 and 1977 . These tests resulted in the first heat exchanger fouling data for Raft River geofluid with various materials and aided in the selection of heat exchanger materials.

In January 1979, the initial test plan for the engineering testing of the plant was completed.

The primary objectives of the tests were:

1. Operation of the plant at full capacity with minimum personnel and minimum environmental impact

2. Determination of the operational and performance characteristics of the system and individual components

3. Development of better design information for future system and component designs

4. Establishment of a data base for predicting operational and performance characteristics of the plant and its components

5. Providing operational and maintenance experience on a binary power plant.

The test plan included steady-state tests of both the system and individual components and transient tests of the control system through the normal transients of the plant. The testing period was to be over a three-year period with a comprehensive testing period at the beginning and the end of testing. During the period between, component performance was to be monitored to detect changes in component performance such as heat exchanger fouling. As mentioned previously, because of reduced funding and technical scope reduction of the project, the testing period was decreased to three months, and only the initial test phase was completed.
Construction of the plant began in August 1979, Title II design of the turbine-generator modification was completed and in September a contract was awarded to make the modification. Construction work was completed, warranty repairs made, and the facility turnover was completed in July 1981.

On September 30, 1979, DOE designated EG\&G Idaho, Inc., as the operating contractor for the plant. Efforts to recruit operating personnel began at that time. Later that year, Westec Services, Inc., was contracted to prepare operational and maintenance procedures. Subsequent to the facility turnover, EG\&G Idaho, the operating contractor, made a number of modifications and began component testing in the spring of 1981 . On September 10, 1981 a final readiness review was conducted, and DOE-ID approved filling the system with isobutane and proceeding with the startup testing.

The startup system operation (SO) and integrated plant (IP) testing were conducted in September and October 1981. Full thermal power was reached during these tests. A mechanical failure occurring in the actuation system of the high-pressure turbine throttle valve rendered the high-pressure turbine stage inoperable. This series of tests, conducted without the high-pressure stage, culminated in the production of $1 \mathrm{MW}(\mathrm{e})$ by the turbine-generator on November 1, 1982. At this time, the plant was shut down for repairs and modification during the winter. In March 1982, the plant was again started, and limited engineering performance tests and a 12-day power run were performed. The plant was shut down on June 15, 1982 and was placed in cold shutdown during the period from June 15 through September 30, 1982. 


\section{PLANT DESCRIPTION}

This section describes the three primary systems of the plant: the geofluid system, the isobutane system, and the cooling water system. The auxiliary systems, such as the cooling water treatment system, are discussed later in the report in the Plant Operation section. The Plant Description section describes the basic power cycle and provides a physical and design description of the primary equipment. The control system is outlined and its operation is explained. Finally, the actual cost of building the plant is discussed.

\section{Power Cycle Selection and Description}

A variety of working fluids and cycles were initially studied for this moderate temperature resource application. It was found that the dual boiling cycle had a significantly better performance than either the single boiling cycle or the supercritical cycle with isobutane working fluid when the resource temperature was below $300^{\circ} \mathrm{F}$.

Figure 1 shows a simplified schematic diagram of the plant. In this figure, the three primary systems are shown with bypass, recirculation, makeup, blowdown, vent, and fill lines omitted. In the Plant Performance section a more complete schematic diagram is shown. Appendix A contains copies of the system piping and instrumentation (P\&I) drawings which represent the system in complete detail. The numbers in Figure 1 represent state points. This numbering system does not have consecutive numbers because one system was used throughout the report and many points have been eliminated from this drawing.

Based on a $290^{\circ} \mathrm{F}$ liquid geothermal resource at the plant, a design base case was established and Table 1 gives the nominal state point and flow values along with a heat-power balance for the design ambient condition $\left(65^{\circ} \mathrm{F}\right.$ wet bulb temperature).

The geofluid entered the plant from three production wells. A geothermal boost pump raised the pressure sufficiently to account for the pressure losses within the plant as the geofluid flows through the heat exchangers and associated piping and valves. (There were pumps in each production well and at each injection well.) The geofluid flowed in series through the high-pressure boiler, the high-temperature preheater, the lowpressure boiler, and the low-temperature preheater. At design conditions, geofluid was to enter the plant at $290^{\circ} \mathrm{F}$ and exit at $144^{\circ} \mathrm{F}$.

In the isobutane loop, slightly subcooled liquid was taken from the condensate storage tank and pumped to the pressure of the high-pressure boiler. The entire isobutane flow passed through the low-temperature preheater exiting at around $180^{\circ} \mathrm{F}$. At this point the flow was split, approximately two-thirds went through the hightemperature preheater and the high-pressure boiler and the other third went through the lowpressure boiler after passing through a control valve which decreased its pressure substantially. This control valve operated to maintain the liquid level in the boiler. The high-temperature preheater heated the liquid isobutane to approximately $240^{\circ} \mathrm{F}$. The liquid was vaporized in the highpressure boiler and the vapor flowed to the highpressure turbine wheel. Similarly, the liquid was vaporized in the low-pressure boiler flowed to the low-pressure turbine wheel. No effort was made to recover the energy lost by throttling the liquid flow into the low-pressure boiler.

The two vapor streams mixed within the turbine casing before flowing to the condenser. In the condenser the vapor was condensed and slightly subcooled before it was returned to the condensate storage tank.

The cooling water which received the energy given up by the condensing isobutane vapor flowed through the condenser with a $20^{\circ} \mathrm{F}$ temperature rise. The cooling water then flowed through a wet cooling tower in which the energy was rejected to the atmosphere. Treated geothermal water was used for cooling water makeup, and was added between the condenser and the cooling tower. Some cooling water left the system as blowdown in the same area.

\section{Physical Description}

The general site arrangement and location of the facility are shown in Figure 2. Because of the flammability of the working fluid, the system was designed using the National Fire Protection Association (NAPA) Standards as the governing 

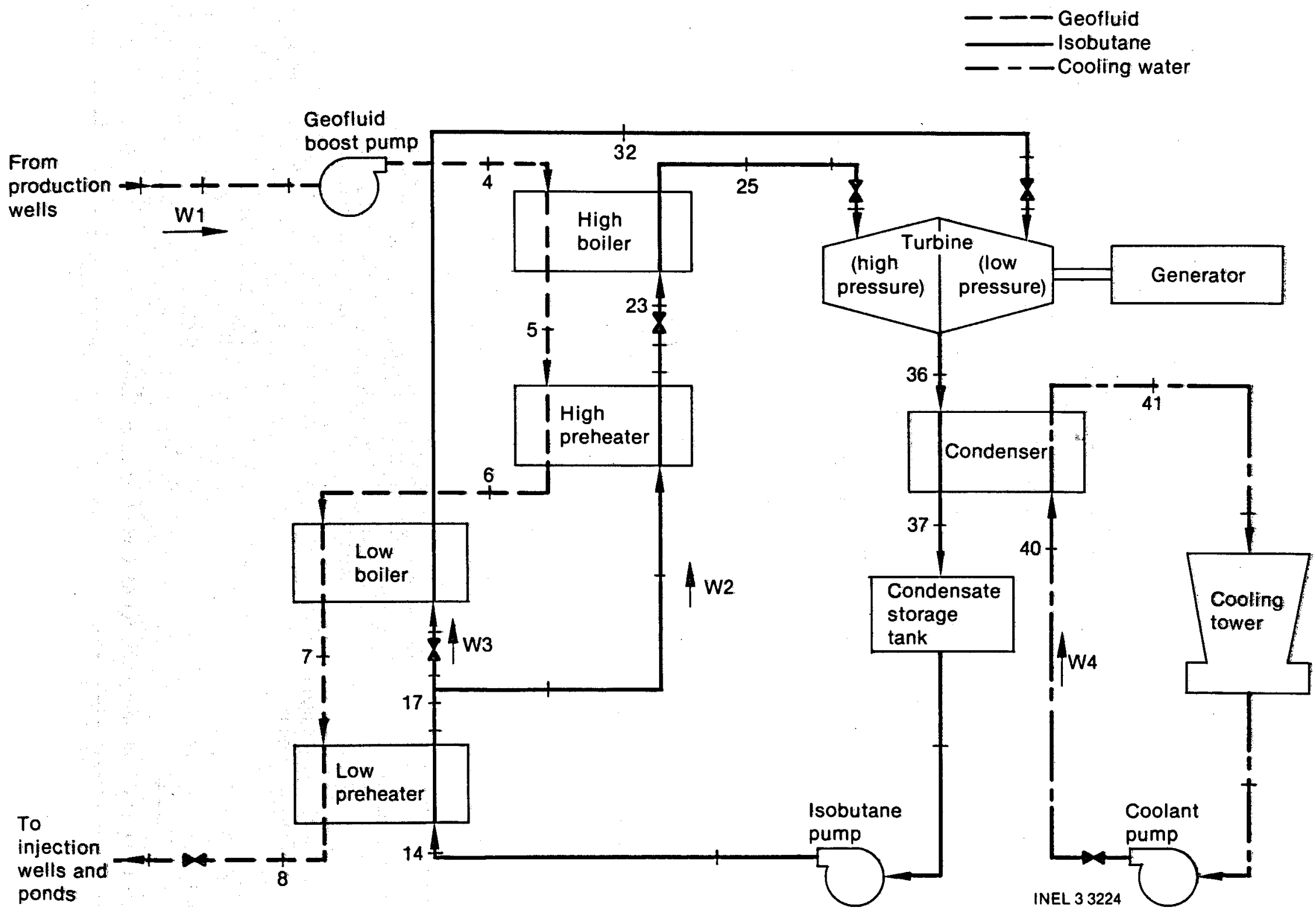

Figure 1. Simplified schematic diagram of the S-MW(e) pilot geothermal power plant. 
Table 1. Nominal design data

State Points ${ }^{a}$

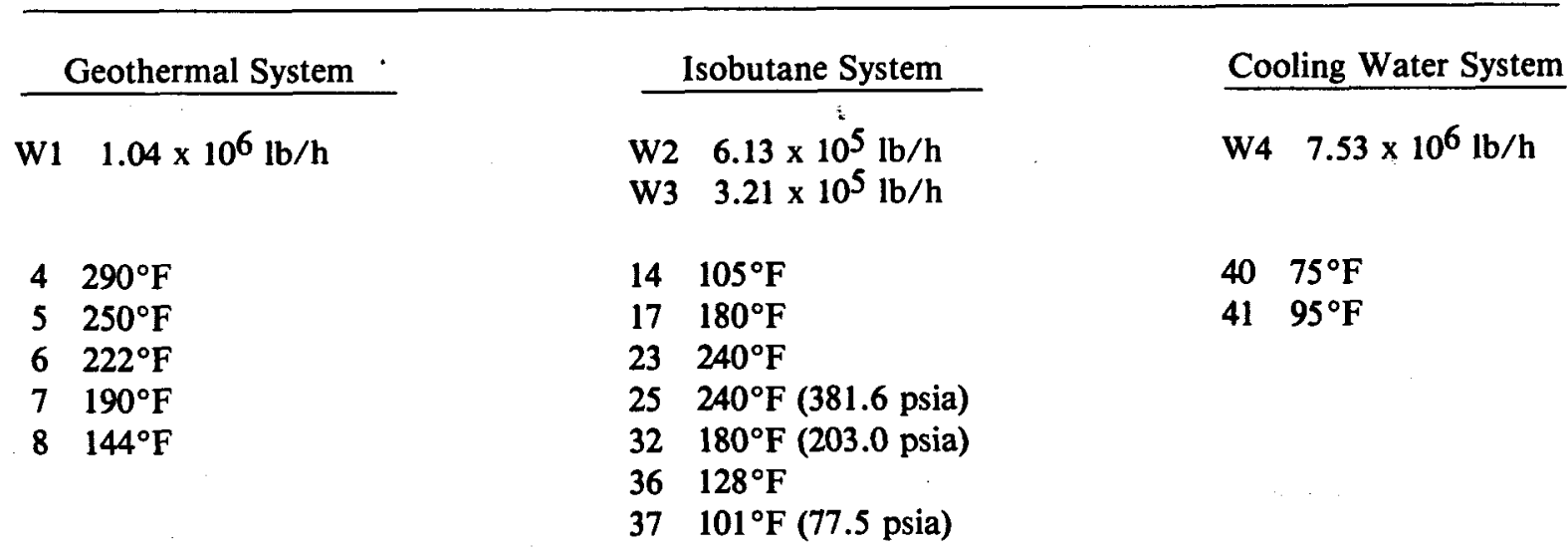

Power Balance

Heat addition $\quad$ MW

Low preheater $\quad 14.0$

Low pressure boiler $\quad 10.0$

High preheater $\quad 8.5$

High pressure boiler $\quad \underline{12.5}$

$\begin{array}{ll}\text { Total } & \mathbf{4 5 . 0}\end{array}$

Heat rejection

$\begin{array}{lr}\text { Condenser } & 40.7\end{array}$

$\begin{array}{ll}\text { Turbine power } & \mathbf{5 . 0}\end{array}$

Parasitic power

$\begin{array}{ll}\text { Feed pump } & 0.7\end{array}$

Cooling tower fan and pump $\quad 0.6$

Geofluid boost pump $\quad \underline{0.1}$

$\begin{array}{ll}\text { Total } & 1.4\end{array}$

Net Power 3.6

a. Design flows and state points for $65^{\circ} \mathrm{F}$ wet bulb temperature. 


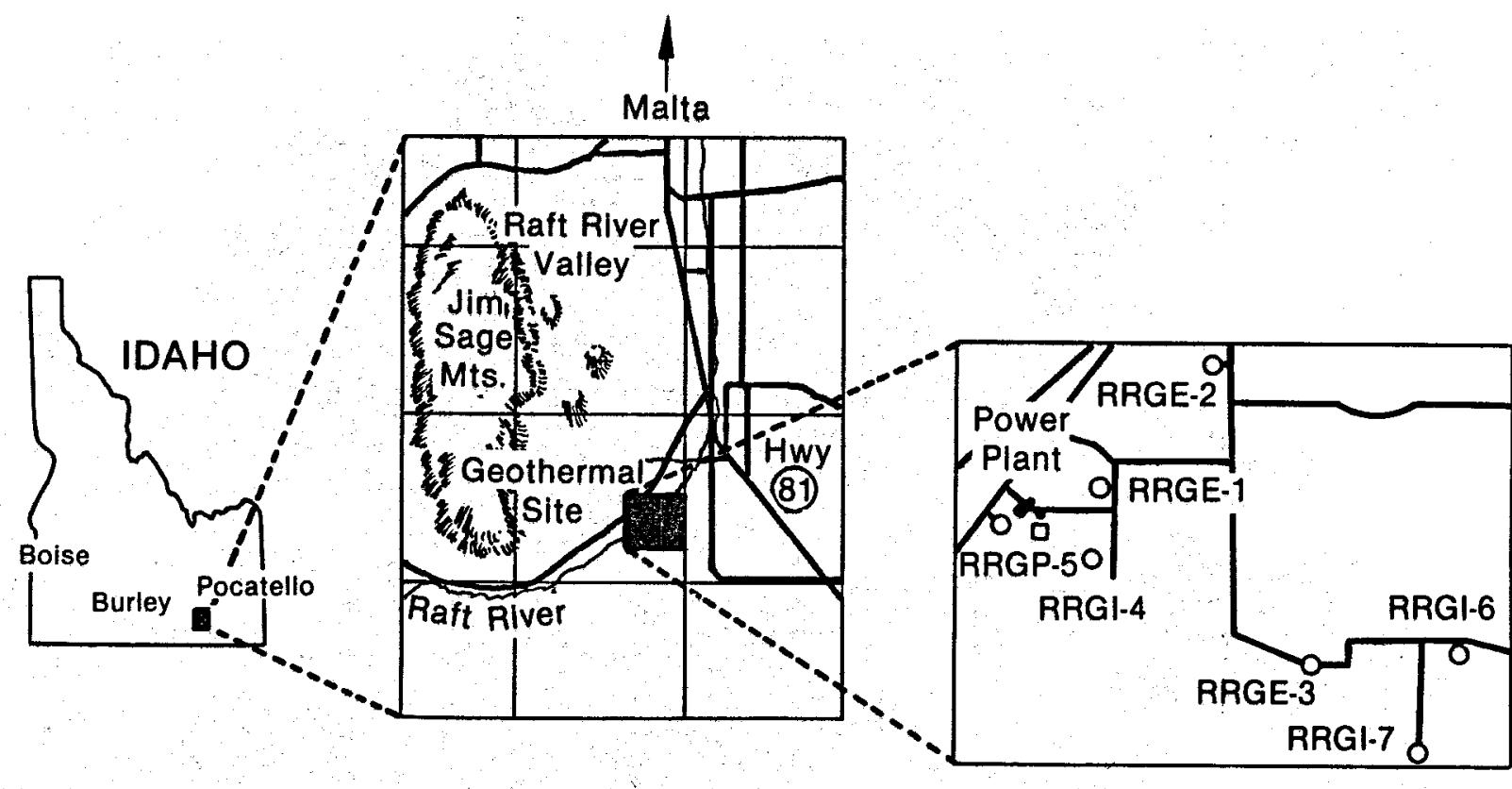

INEL 33198

Figure 2. Raft River geothermal site.

code. Power plants, however, are not specifically included in the facilities covered by the code. Accordingly, NFPA No. 59, "Standards for the Storage and Handling of Liquefied Petroleum Gases at Utility Gas Plants" was selected to provide additional governing specifications, and was supplemented by the ASME Boiler and Pressure Vessel Code (Section VIII), the Power Piping Code (ANSI 31.1), and the Refinery Piping Code (ANSI 831.3).

The geofluid system had a design pressure and temperature of $250 \mathrm{psig}$ and $320^{\circ} \mathrm{F}$. The isobutane system (with the exception of the condenser) design conditions were $650 \mathrm{psig}$ and $320^{\circ} \mathrm{F}$. The condenser was designed to lower pressure and temperature conditions of $230 \mathrm{psig}$ and $280^{\circ} \mathrm{F}$. The design pressures were selected to permit the use of propane as an alternate working fluid because studies had shown that at the geofluid temperatures expected at Raft River the preferred working fluid was in a region of change from isobutane to propane.

Figure 3 is an aerial view of the entire facility. The control, office, and laboratory buildings are shown in the upper right part of the picture and the maintenance building is behind it. The cooling tower and adjacent water treatment building are on the lower right. The main process area is on the left and the storage tanks are in front of the process area,

Figure 4 shows a closeup view of the process area from the opposite side from that shown in Figure 3. The low-temperature preheater is the heat exchanger on the lower right. Above it is the low-pressure boiler. Behind the low-pressure boiler are the high-temperature preheater and the high-pressure boiler. Behind these exchangers is the condenser and below the condenser is the condensate storage tank. The turbine, gearbox, and generator rest on a platform behind the condenser, and the lubricating and sealing oil system is located below the turbine.

\section{Component Descriptions}

Isobutane feed Pumps. The working fluid pumping was provided by two parallel vertical turbine pumps rated at $1514 \mathrm{ft}$ and $1747 \mathrm{gpm}$ each. Each pump had six stages and a 500 -hp motor. The pump efficiency at rated conditions was specified at $78 \%$. The pumps were sized for the minimum condenser pressure of 42 psia.

Geothermal Boost Pumps. The geothermal boost pumps provided the pressure increment 


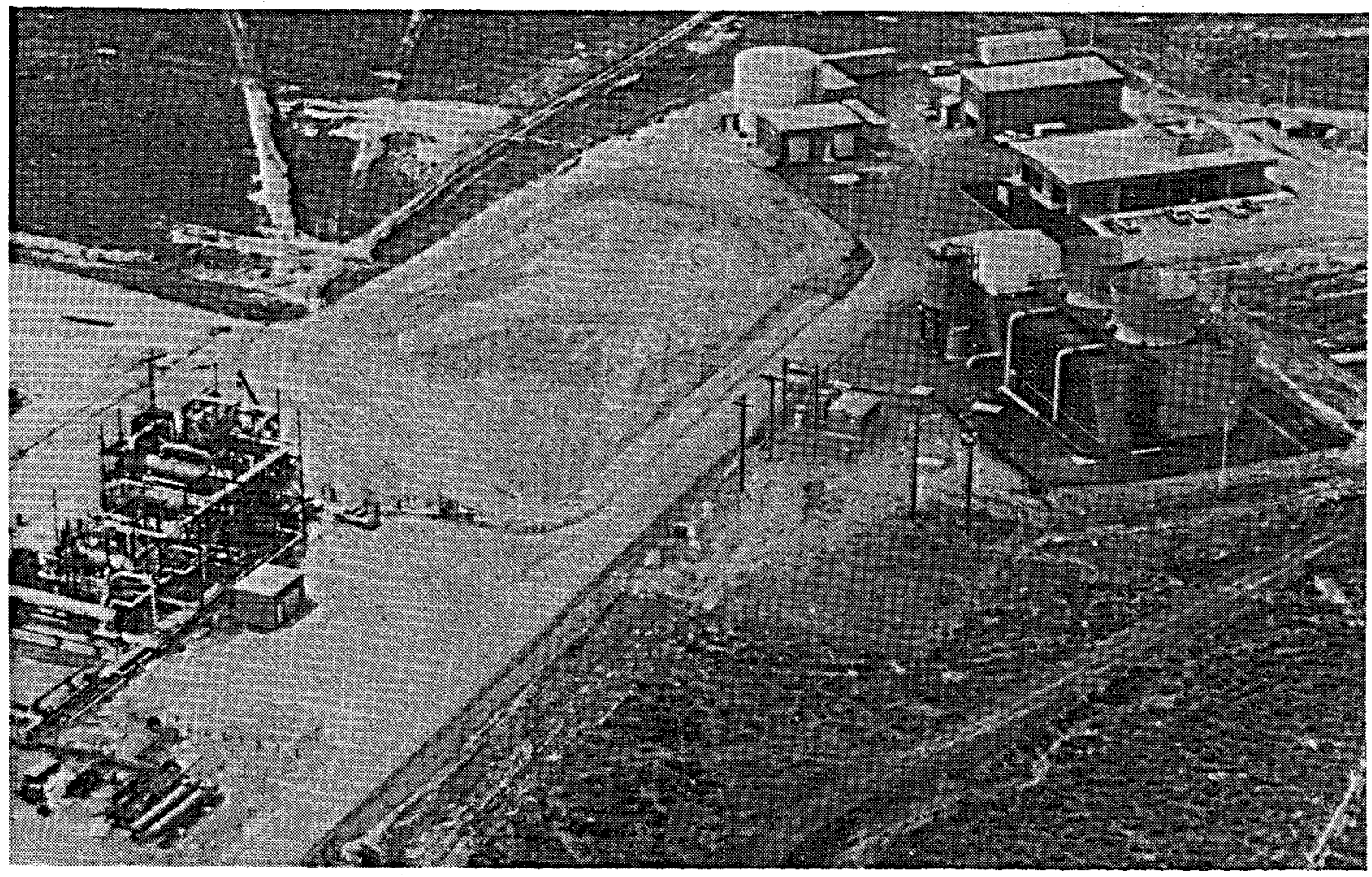

Figure 3. An aerial view of the 5-MW(e) pilot plant facility. Top right: control, office, and laboratory building and maintenance building. Lower right: cooling tower and adjoining water treatment building. Left: process area, hydrocarbon storage, and nitrogen tanks.

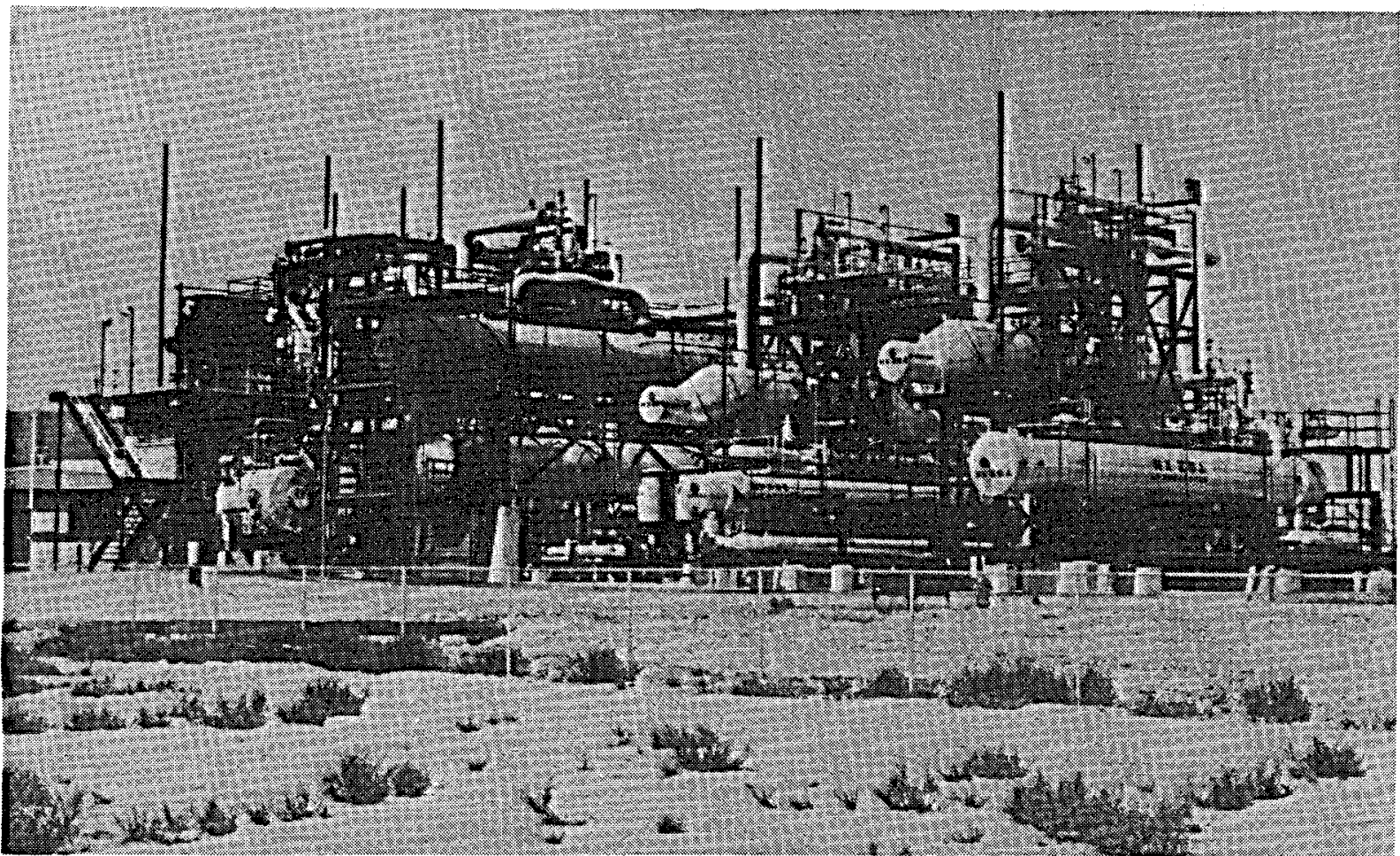

Figure 4. The Raft River 5-MW(e) pilot plant process area. Right: low-pressure preheater (lower) and low-pressure boiler (upper). Center: high-pressure preheater (lower) and high-pressure boiler (upper). Left: condenser (upper) and condensate receiver (lower). Extreme left: generator (upper) and oil system (lower). 
required to pump the geofluid through the heat exchangers and through the transmission lines to the injection pumps. Two parallel, vertical-split case centrifugal pumps (each with a head of $272 \mathrm{ft}$ at a flow of $1115 \mathrm{gpm}$, a design efficiency of $80.5 \%$, and driven by a 125 -hp electric motor) provided this capability.

Cooling Water Pumps. The pumping required to move the cooling water through the condenser and cooling tower was provided by two parallel vertical turbine pumps. At rated conditions, each pump provided $7700 \mathrm{gpm}$ of water at $125 \mathrm{ft}$ head. At these conditions, the efficiency was specified as $83 \%$. Each pump was driven by a 300 -hp motor.

Heat Exchangers. The heat exchanger characteristics are summarized in the following table:

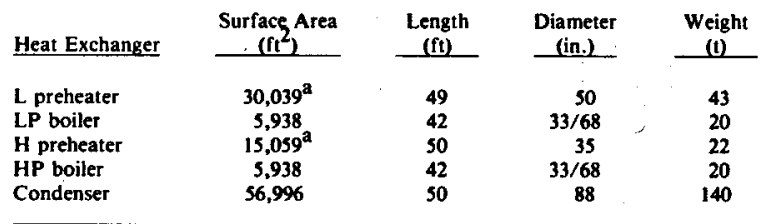

a. Extended surface.

The tube material for all geothermal heat exchangers was admiralty brass. The tube sheets were aluminum bronze clad carbon steel. The geothermal side fouling factor was assumed to be $0.0015 \mathrm{~h} \mathrm{ft}^{2}{ }^{\circ} \mathrm{F} / \mathrm{Btu}$, and $0.0005 \mathrm{~h} \mathrm{ft}{ }^{2} \mathrm{~F} / \mathrm{Btu}$ was used on the isobutane side. The condenser was made of carbon steel throughout, including the tubes. For design of the condenser, the cooling water side fouling factor was taken as $0.0010 \mathrm{~h} \mathrm{ft}{ }^{\circ} \mathrm{F} / \mathrm{Btu}$, and an isobutane side fouling factor of $0.0005 \mathrm{~h} \mathrm{ft}^{2 \circ} \mathrm{F} / \mathrm{Btu}$ was used.

Cooling Tower. The cooling tower was a crossflow, two-cell, mechanical draft, wet unit. Each of the 40 by $70-\mathrm{ft}$ cells was equipped with a fan which had an 80-hp motor. The tower was $53 \mathrm{ft}$ high and was constructed of treated Douglas fir and redwood.

Turbine Generator. The turbine, manufactured by the Elliot Company, utilized the barrel design. This design was easy to seal for high-pressure service, and would facilitate disassembly and reassembly for maintenance. The rotor had two radial inflow wheels. Because the flow from the low- and high-pressure inlets were combined to a common outlet, the aerodynamic thrust load was low.
The generator was rated at $7200 \mathrm{~kW}, 7579 \mathrm{kVA}$, $1200 \mathrm{rpm}$ synchronous speed, and electrical conditions of three-phase, $60 \mathrm{~Hz}$ and $4160 \mathrm{~V}$. The generator design power factor was $\mathbf{0 . 9}$.

The speed-reduction gearbox was designed to transmit the full $7579 \mathrm{kVA}$ generator rating with a minimum continuous service factor of 1.1 . The gears were rated for $8000 \mathrm{rpm}$ input speed and $1200 \mathrm{rpm}$ output speed.

\section{Supply and Injection System}

All of the lines in the supply and injection system were made of cement-asbestos pipe with transition to steel pipe at the wells, at the plant, and at a manifold into which the individual production-wall pipelines joined. The pipe was buried to an average depth of 3.5 to $4.5 \mathrm{ft}$. The supply lines were insulated with urethane foam to limit the temperature drop to less than $1.5^{\circ} \mathrm{F}$ per mile. A diagram of the supply and injection system pipelines is included in the Plant Operation section as Figure 9.

Line-shaft pumps were installed in each supply well. At each injection well, the line dumped into a pond, and then the geofluid was pumped from the pond and injected with individual pumps. A summary of individual well information is given in the Plant Operation section.

In the normal operation of the plant, Wells RRGE-1, RRGE-2 and RRGE-3 were used as production wells and RRGI-6 and RRGI-7 as injection wells. Well RRGE-4 was inoperable, and RRGE-5 was used only in the artesian flow mode for warmup of the cement-asbestos lines after a system shutdown.

\section{System Control Description}

Figure 5 is a schematic diagram showing the control system with bypass and recirculation lines inducted. The control valves are noted as $\mathrm{Cl}$ through $\mathrm{C} 11$ and the trim valves by $\mathrm{T} 1$ through T3.

In steady-state, power producing operation, Valves $\mathrm{Cl}$ and $\mathrm{C} 2$ were closed and $\mathrm{C} 3$ was opened. This allowed the entire geofluid flow to go through the plant. The primary control in the isobutane loop was exerted by Valves $\mathrm{C4}$ and $\mathrm{C} 5$. 

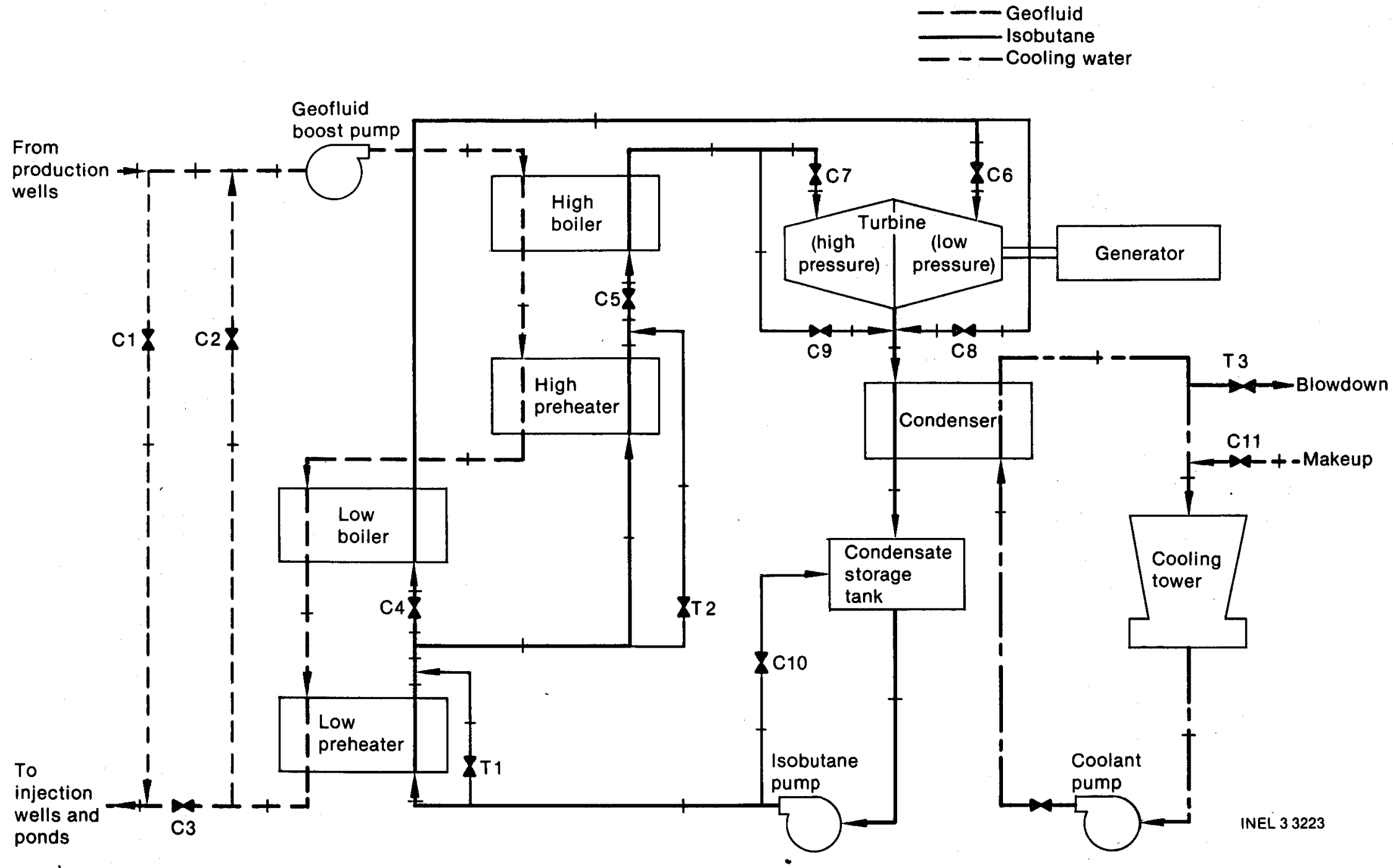

Figure 5. Schematic diagram of the control system for the 5-MW(e) pilot geothermal power plant. 
These valves operated to maintain a constant liquid level in each boiler. Valves $\mathrm{C} 6$ and $\mathrm{C7}$ were the throttle valves which were adjusted to maintain generator output. Valves C8 and C9 were closed so that the entire vapor flow passed through the turbines.

In normal operation, Valve $\mathrm{C} 10$ was closed. During a transient, this valve would open to maintain a constant flow through the isobutane feed pumps by opening to allow flow to bypass the main system when vapor generation rates decreased and the boiler feed valves (C4 and C5) began to close.

Similarly, in normal operation, Valves C8 and $\mathrm{C} 9$ in the turbine bypass lines were controlled by boiler pressure. They remained closed until the boiler pressure (low-pressure boiler for C8 and high-pressure boiler for $C^{9}$ ) reached a predetermined level and then opened. This process served to prevent the lifting of the relief valves during a turbine trip. When a turbine trip occurred, Valves $\mathrm{C} 6$ and $\mathrm{C} 7$ immediately closed. (The throttle valves also served as the stop valves.) The boiler vapor flow was then cut off and the boiler pressure rose. Valves $\mathrm{C} 8$ and $\mathrm{C} 9$ were designed to come open to allow bypass around the turbines in order to establish thermal loop conditions. Some problems with this scheme are discussed in the Plant Performance and Plant Operations sections.

The makeup water input into the cooling tower basin was controlled by Valve C11 to maintain a constant level in the basin. The cooling water blowdown flow was set with Trim Valve T3.

The valves designated as $T 1$ and $T 2$ were trim valves for maintaining the isobutane upstream of the Control Valves C4 and C5 in the subcooled liquid state in order to prevent excessive cavitation and flashing in $\mathrm{C4}$ and $\mathrm{C5}$. The necessity of this procedure is discussed in References $1,2,6$, and 7.

During a startup or shutdown, Control Valves $\mathrm{C1}, \mathrm{C2}$, and $\mathrm{C3}$ were used. These three valves were controlled by the temperature of the geofluid entering the plant. When the setpoint for the temperature was below the measured value, Valves $\mathrm{C} 1$ and $\mathrm{C} 2$ closed and $\mathrm{C} 3$ opened, allowing less of the hot geofluid from the production wells into the system to mix with the colder recirculating stream (through Valve $\mathrm{C} 2$ ). Conversely, when the demand was for a higher geofluid temperature, the valves moved in the opposite direction causing more hot fluid to enter the system.

Startup was initiated with Valves $\mathrm{Cl}$ and $\mathrm{C2}$ open and Valve $\mathrm{C} 3$ closed. All of the geofluid from the production wells flowed through $\mathrm{Cl}$ to the injection wells. The geofluid boost pumps were started, recirculating cold geofluid through $\mathrm{C} 2$ and the heat exchangers. Valves $\mathrm{C} 6$ and $\mathrm{C} 7$ were closed and $\mathrm{C} 8$ and $\mathrm{C} 9$ were open, putting the system into the thermal loop mode. Valves $\mathrm{C} 4$ and $C 5$ were in the automatic mode, but were closed because there was no vapor being generated by the boilers.

The isobutane pumps were started with Valve C10 in automatic mode. In order to maintain a constant flow through the isobutane pumps, Valve $\mathrm{Cl0}$ was open because there was no flow going through the boilers. Energy from the pumps was put into the isobutane until its pressure and temperature increased to the point at which the boiler levels were to be set. At this point, the temperature controller for Valves $\mathrm{C1}, \mathrm{C2}$, and $\mathrm{C3}$ was used to ramp the temperature of the geofluid up to its desired value. During startup and shutdown, the rate was kept below $40^{\circ} \mathrm{F} / \mathrm{h}$ to avoid thermal shock in the heat exchangers and supply and injection system piping. Valves C4 and C5 opened automatically as vapor was generated, and Valve C10 closed as they opened. When the maximum geofluid temperature was reached, Valves $\mathrm{Cl}, \mathrm{C2}$, and $\mathrm{ClO}$ were closed and $\mathrm{C} 3$ was opened.

At this time, the turbine could be brought up to speed and synchronized with the electric grid. This was done by opening Valves $\mathbf{C 6}$ and $\mathbf{C 7}$ in a manner prescribed by the turbine manufacturer. (The turbine was brought up to speed by a series of step flow increases and then holding to establish thermal equilibrium at each step. The acceleration of the turbine was accomplished by the low-pressure stage with only enough flow through the highpressure stage to keep it from overheating.) After the turbine reached design speed, it -was synchronized. Then as the load was increased, more flow was introduced into the high-pressure stage of the turbine. The governor ganged the two throttle valves together to respond to load changes. Valves C8 and C9 were finally closed, and the operating mode was achieved. 
Shutdown of the system was the reverse of the startup procedure.

\section{Plant Construction Costs}

Table 2 shows a summary of major material and labor costs for the construction of the plant. The turbine generator costs contain the modifications necessary to convert the svstem from a ther- mal loop facility to a power generating plant. Some of these costs include piping modifications and additional structure.

Table 3 gives a more detailed breakdown of the costs associated with four major plant systems: isobutane, geothermal, cooling water, and turbine generator. These costs do not include costs associated with the geothermal wells, pumps, supply and injection piping system, or project management.

Table 2. Construction cost summary

\begin{tabular}{|c|c|c|c|c|c|}
\hline \multirow[b]{2}{*}{ System } & \multicolumn{2}{|c|}{ Material } & \multicolumn{2}{|c|}{ Labor } & \multirow{2}{*}{$\begin{array}{c}\text { Total } \\
\text { Material } \\
\text { and } \\
\text { Labor } \\
(\%) \\
\end{array}$} \\
\hline & $\begin{array}{c}\text { Cost } \\
\mathbf{( \$ 1 0 0 0 )} \\
\end{array}$ & $\begin{array}{l}\text { Total } \\
(\%)\end{array}$ & $\begin{array}{c}\text { Cost } \\
(\$ 1000)\end{array}$ & $\begin{array}{c}\text { Total } \\
(\%)\end{array}$ & \\
\hline Isobutane & 1980 & 15 & 450 & 4 & 19 \\
\hline Turbine-generator ${ }^{a}$ & 1900 & 15 & 300 & 2 & 17 \\
\hline Cooling & 780 & 6 & 200 & 2 & 8 \\
\hline Instrumentation and control & 650 & 5 & 200 & 2 & 7 \\
\hline Water treatment & 400 & 3 & 50 & 0.4 & 3 \\
\hline Fire & 250 & 2 & 150 & 1 & 3 \\
\hline Holding ponds & 150 & 1 & 150 & 1 & 2 \\
\hline Geothermal & 200 & 2 & 82 & 0.6 & 2 \\
\hline Flare & 85 & 0.7 & 85 & 0.7 & 1 \\
\hline Nitrogen & 91 & 0.7 & 18 & 0.1 & 1 \\
\hline Instrument air & 16 & 0.1 & 22 & 0.2 & $\leq 1$ \\
\hline Other construction costs & 825 & 6 & 675 & 5 & 11 \\
\hline Total construction costs & 7327 & 56 & 2382 & 19 & 75 \\
\hline Engineering and design & - & - & 1322 & 10 & 10 \\
\hline Indirect ${ }^{b}$ & 一 & - & 2000 & 15 & 15 \\
\hline Total & 7327 & 56 & 5704 & 44 & 100 \\
\hline
\end{tabular}

a. The material cost includes some installation, platform construction, and any extras necessary for operation.

b. Includes administration and overhead of contractors and subcontractors. The dollars shown represent costs at the time they were incurred during design and construction, an average in this 1978 time period. 
Table 3. Component material cost summary

Cost

$\underline{(\$ 1000)}$

Isobutane

Condenser/condensate storage tank 400

High and low temperature preheaters

High and low pressure boilers.

Isobutane feed pumps

130

Storage tanks

70

Pipes, valve, miscellaneous

Total

1980

Geothermal System

Geofluid boost pumps

Pipes, valves, miscellaneous

Total

Cooling System

Cooling tower

Pumps

Pipes, valves, miscellaneous

Total

Turbine Generator

Turbine-gearbox-generator 


\section{PERFORMANCE ANALYSIS}

\section{Background}

Test Program. An extensive testing program was initially planned for the pilot power plant. References 1 and 2 contain the first test plan and its revisions and updates. The plan included a test period lasting approximately three years. Initially, performance testing of the system and the individual components was to proceed at the earliest possible time. Then testing was to proceed at a lower level to detect changes in performance with time (due to effects such as heat exchanger fouling and wear in equipment). Another period of intensive testing at the end of two years was to document the long-term changes in performance due to effects such as fouling.

When the scope of testing was reduced to a twomonth period, as discussed in the Introduction, it was decided to proceed with the same basic test matrix that was proposed for the initial testing phase of the longer duration test. This test matrix was to investigate the system output (power) and its relation to the input parameters: geofluid inlet temperature and flow rate and cooling water temperature and flow rate. It was felt that this would give component operating conditions at near design conditions as well as off-design conditions.

Table 4 summarizes the major tests performed. The time that each test began is indicated along with the desired and actual values of the controlled variables. Three notable deviations from the test specifications are shown. First, the maximum coolant flow rate achieved was approximately $78 \%$ of the specified value. This was a result of the actual performance of the coolant pumps being lower than the design value. (The reasons for this are discussed in the Pump Performance section.) Second, the cooling water temperature was not controlled to the desired value but allowed to float. The operations staff felt that adjusting the cooling tower to maintain constant coolant temperature to the condenser could not be done without jeopardizing the entire system because of the potential inability of the cooling water treatment system to conform with the variable demand in the system. Therefore, coolant temperature variations were taken into account when the data were analyzed.

The third deviation consisted of part of the tests being run without the turbine. In the early stages

Table 4. System performance test matrix

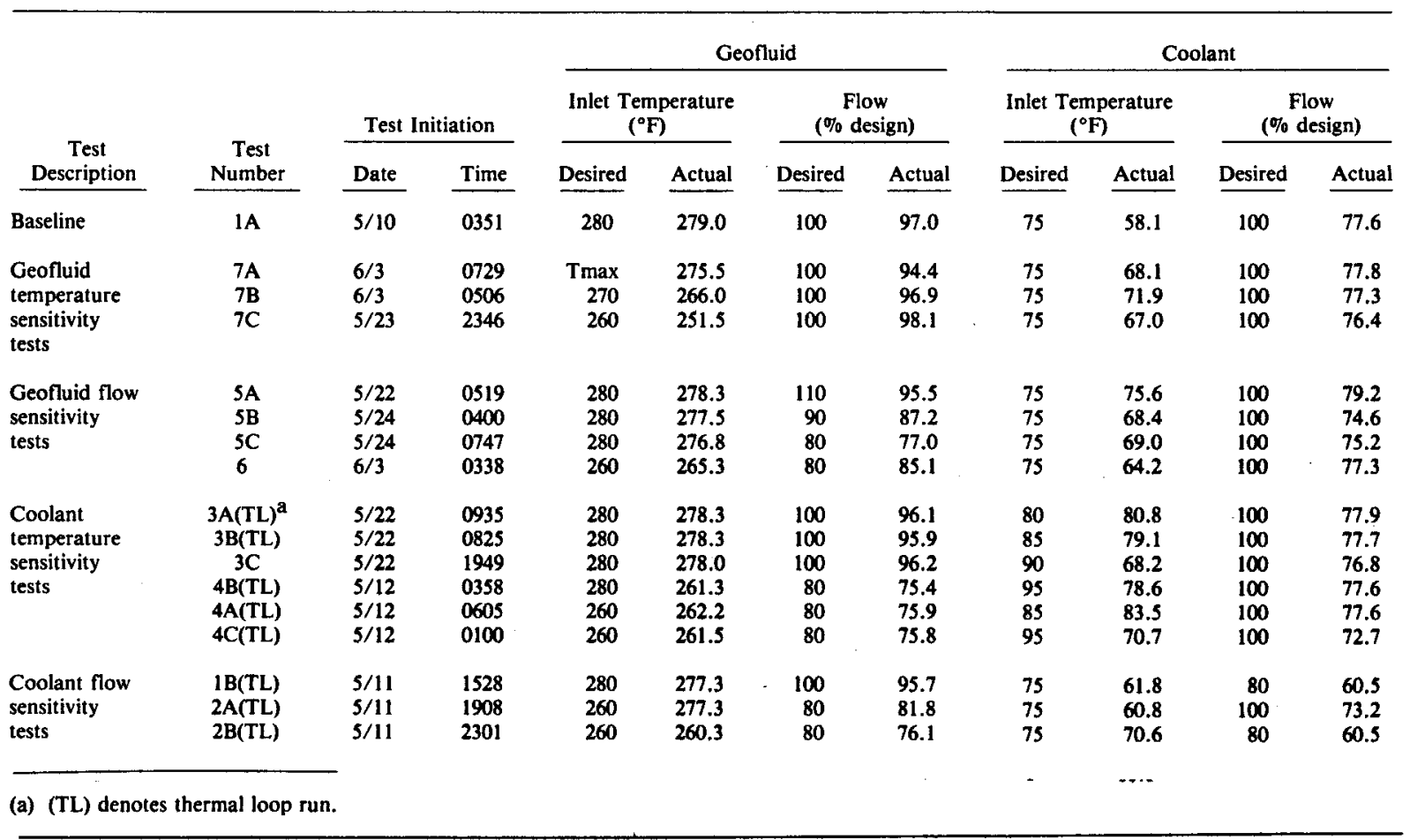


of testing, the turbine was down for an indeterminate period of time. At this time, a decision was made to carry out the testing without the turbine and then repeat selected tests when the turbine was fixed. Eight tests (marked in Table 4) were run in this thermal loop mode. After the turbine was repaired, consideration was given to rerunning these conditions with the turbine operating in order to obtain a complete set of data; however, the decision was made to run the system at steady conditions to obtain some operational data rather than risk an inadvertent shutdown when changing operating points to meet test conditions.

In addition to the performance test series shown in Table 4, the system was run during the previous month, at which time the maximum power generated during operation was obtained. At this time, the indication on the data acquisition system computer was $4465 \mathrm{~kW}$. (The panel meter read by the operator was $4700 \mathrm{~kW}$.) After the test series, the plant produced power for approximately 12 days. Unfortunately, during this period of time, the turbine bypass valve on the low-pressure side of the isobutane loop was stuck open, but was undetected. These results are, therefore, not typical from a performance perspective.

In addition to, and preceding the performance test series, some special tests were conducted to consider certain perceived operational problems. Special tests were run on the isobutane feed pumps and the cooling water pumps. A series of tests were performed to correlate the liquid entrainment in the boiler exhaust with liquid levels in the boilers. These tests are discussed in detail later in this report.

Instrumentation and Data Collection. During the time in which the plant was operating, large quantities of experimental data were recorded. The computer data acquisition system was capable of recording 213 instrument outputs. Additional information concerning the water treatment system, various pumps, and atmospheric conditions were also tabulated. Figures 6, 7, and 8 show the locations of the pressure, temperature, flow, and level sensors in the isobutane, geofluid, and cooling water flow paths, respectively. Analysis of the data indicated that some of these instruments were not functioning correctly; these instruments are noted with asterisks on the figures. In the isobutane system, 24 out of 97 instruments malfunctioned for part of the testing period. In the geothermal loop, 8 out of 28 malfunctioned, and in the cooling water loop 6 out of 18 instruments malfunctioned. Because of the redundancy in instrumentation, these failures had minimum impact on the reduced data. In general, where redundancy existed averages were taken, and where it did not, single values were used.

Thermodynamic and Transport Properties. Early in the project, concern was expressed that thermodynamic and transport properties of the working fluid were not well enough known to design and predict performance. Experience here indicates that the properties used adequately describe the system.

The geothermal fluid and cooling water properties were taken to be those of pure water. The concentration of impurities in both of these systems was small enough to allow very good approximation. The 1967 ASME Steam Tables (Reference 3) was the source of the thermodynamic properties of water. Some of the data reduction was made using a digital computer program that uses the equations from the ASME Steam Tables and has been verified against it.

The isobutane properties were obtained from Reference 4 which uses Starling's modification of the Benedict-Webb-Rubin equation of state. Again, some data reduction was done in a computer program that uses these equations. Starling has recently modified the constants in his equation to obtain better agreement with experiment. The new constants were not used in any of the data reduction, however, checks made for several examples indicated that the changes are quite small, and would not noticeably alter the final results.

The viscosities and thermal conductivities needed in the heat exchanger analyses were obtained from a computer program developed by Ely and Hanley of the National Bureau of Standards. This program used a variation of the law of corresponding states and methane properties. This program is described in Reference 5 .

\section{Data Reduction}

This section discusses the method by which the data was reduced, special test data used in making the reduction and the accuracy of the results. As a result of the number of redundant instruments 


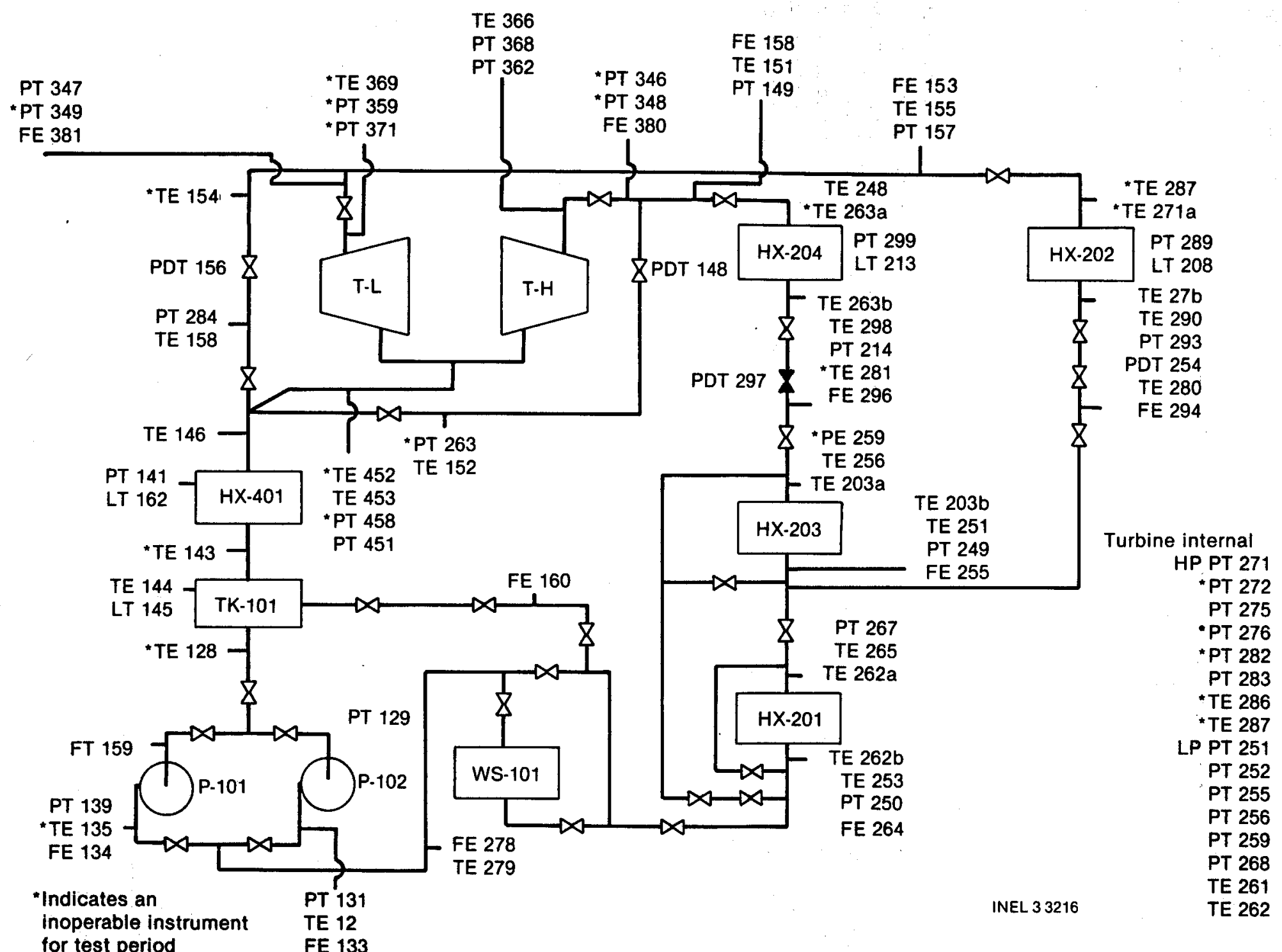

Figure 6. Instrumentation in the isobutane system. 


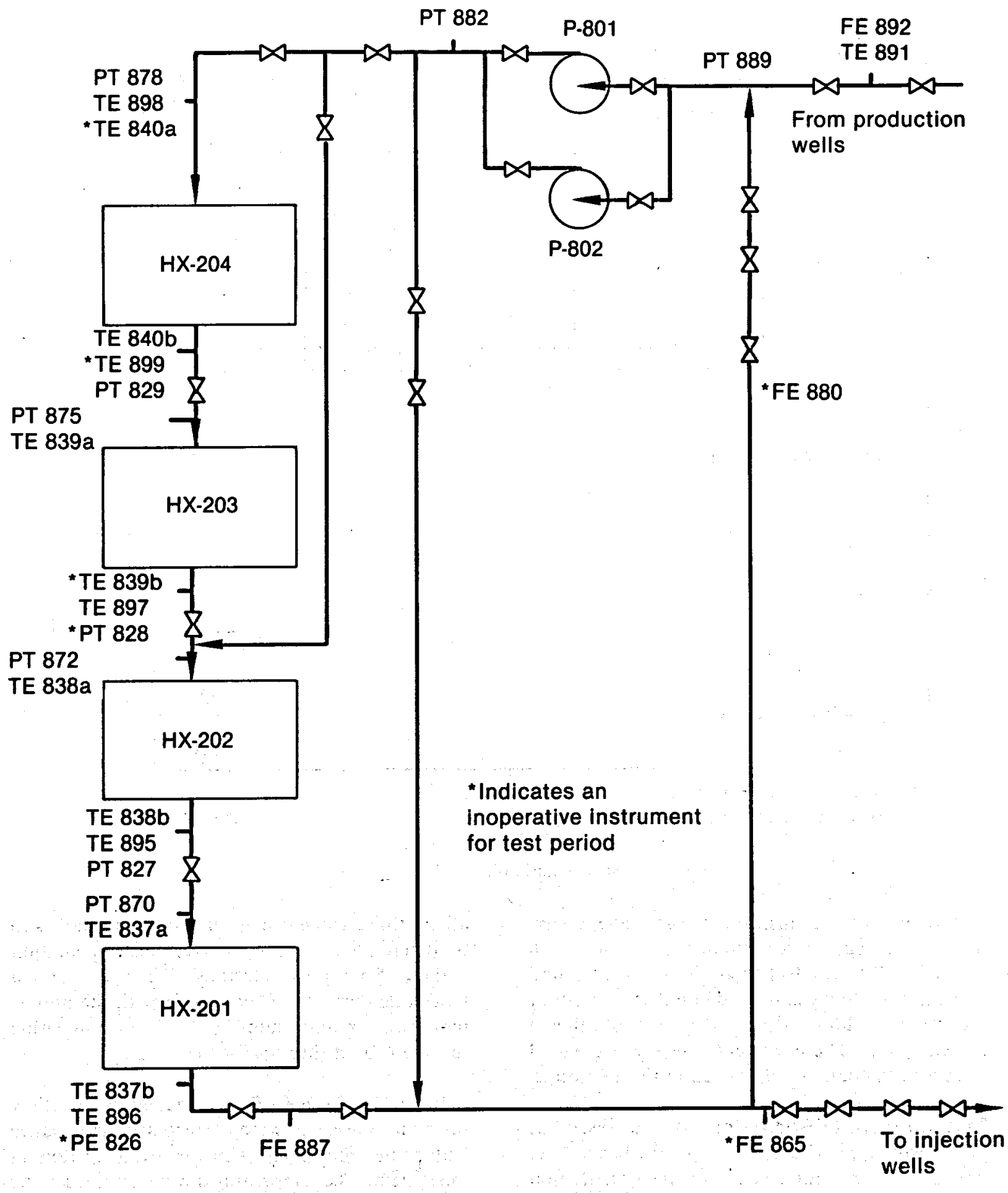

INEL 33218

Figure 7. Instrumentation in the geofluid system. 


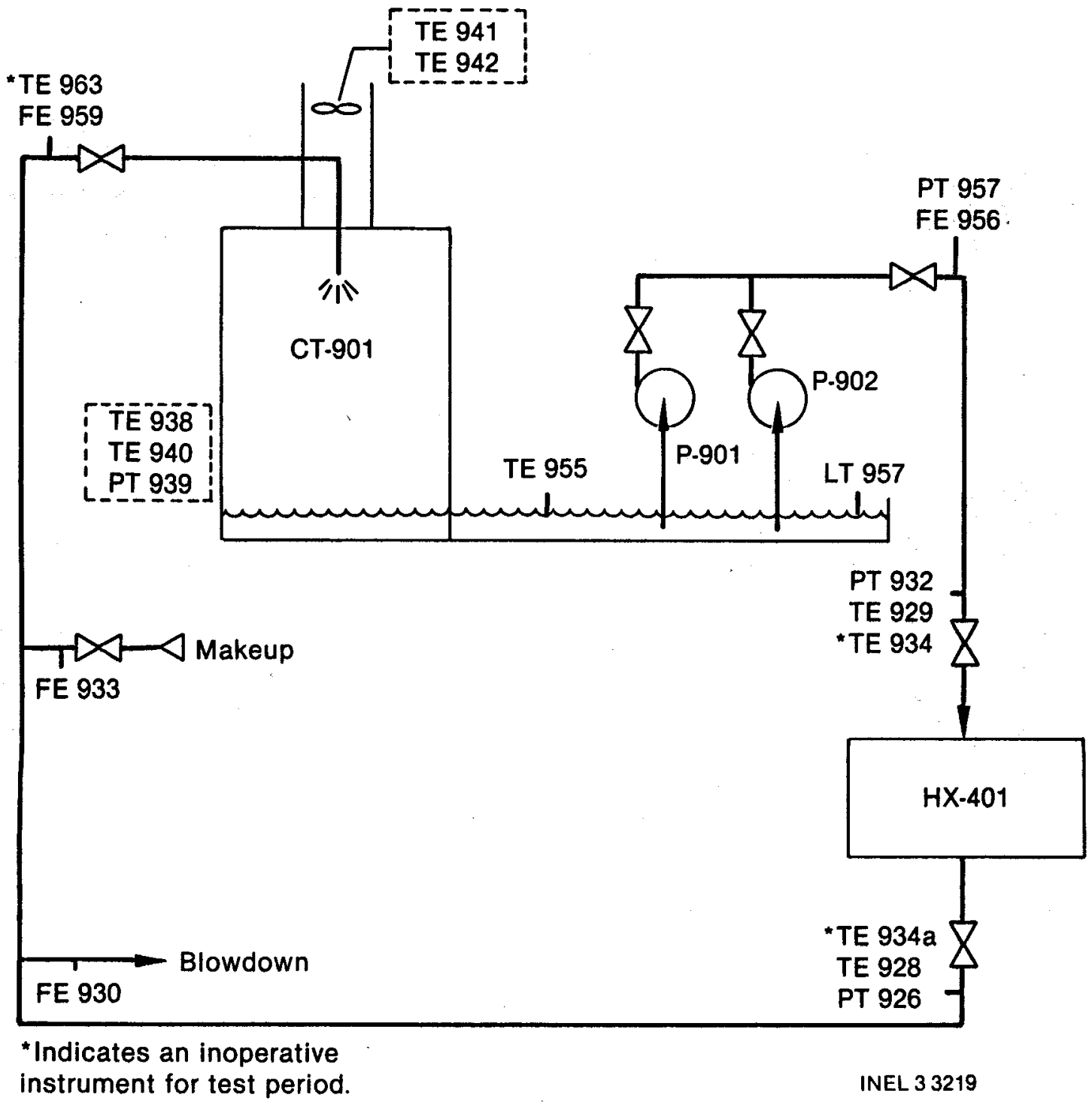

Figure 8. Instrumentation in the cooling water system.

and failed instruments, there was some uncertainty with respect to certain measurements which was difficult to resolve. In addition, it was found that there was some entrained liquid carried out of the boilers. Additional tests were run to estimate this carryover. These tests and how they were used to reduce the data are discussed in this section.

Method of Data Reduction. As was discussed previously, approximately $27 \%$ of the basic flow, pressure, temperature, and level instrumentation was not functioning correctly during the test period. Some of these instrument failures were detected only after the data were taken and considered as a whole. Fortunately, there was a degree of redundancy in the instrumentation that allowed all but three of the system state point properties to be determined from the correct instrumentation without further assumptions. Figure 9 shows a schematic diagram of the system with the important state points numbered. This numbering scheme is used throughout the report.

In the first stage of data reduction, the flow rates and pressures were corrected in accordance with some data taken when there was no flow in the system. The temperatures were assumed to be correct. Redundant measurements were averaged to give a best estimate of the values. The boiler outlet qualities were determined from tests discussed earlier, using an interpolation scheme discussed in that section. 


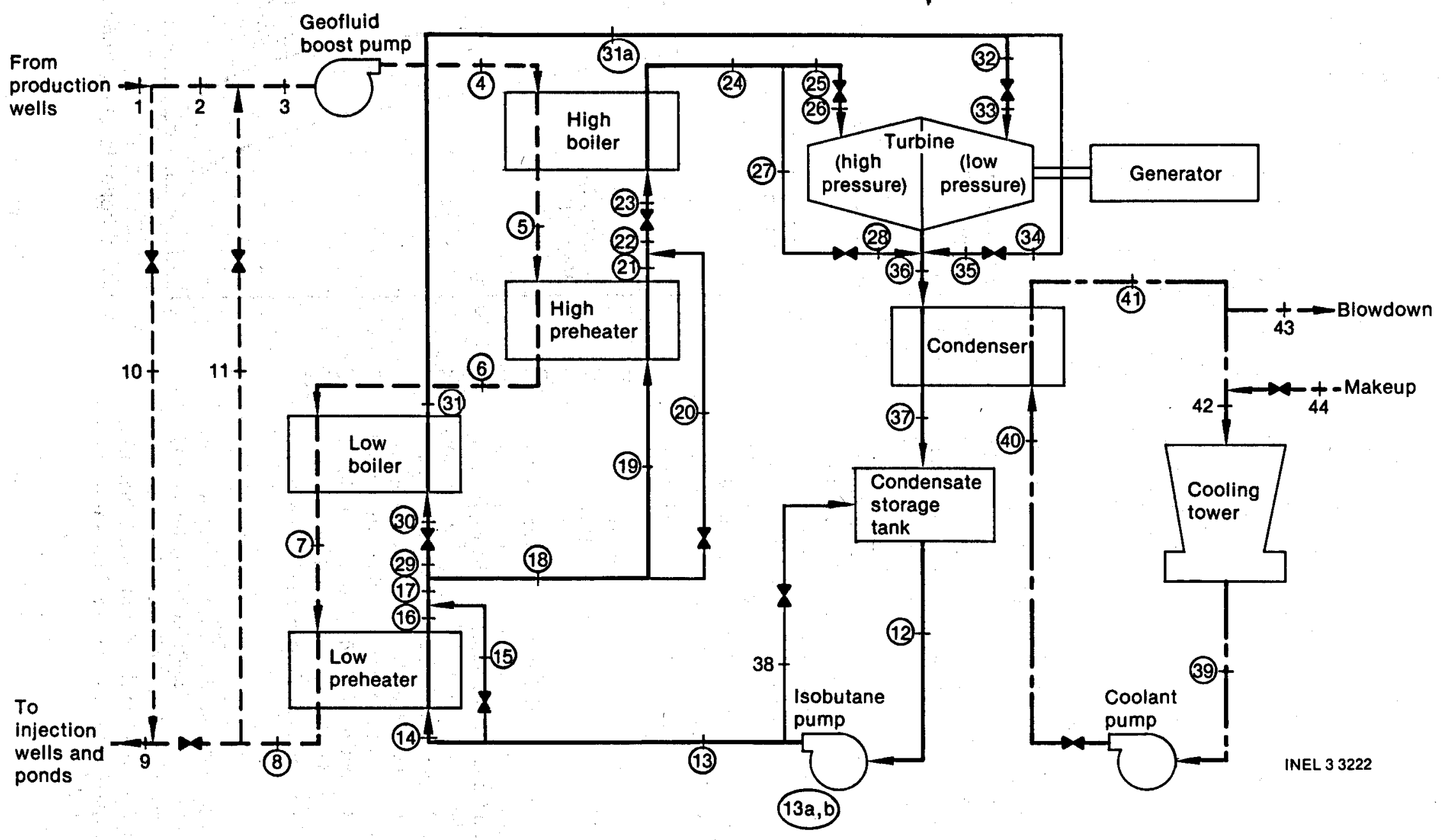

Figure 9. Detailed schematic diagram of the 5-MW(e) pilot geothermal power plant. 
Each preheater had the possibility of a bypass flow around it. Energy balances at the point where the bypass flow was mixed with the heater output flow were used to determine the bypass flows because there were no flowmeters in the line. Other flowmeters were used to estimate the bypass, but this method proved less consistent than the energy balance technique.

There were two flow measurements of the geofluid and cooling water. The mass flow rate from each measurement was calculated and the average of the flows were used for the remaining calculations. The isobutane mass balance was more difficult to obtain. The total isobutane flow was measured between the feed pumps and the low-temperature preheater. At that point, the flow splits into the high-pressure boiler flow and the low-pressure boiler flow. Three experimental measurements of the total isobutane flow were made. In addition, assuming that the geofluid and cooling water flow rates are correct, energy balances could be used to estimate the isobutane flow rate. In the high-pressure boiler line, there were four measurements and two energy balances that were used to estimate the flow. In the lowpressure boiler line, there were three measurements and one energy balance. The sum of the boiler flows should be equal to the total flow. The difference between the sum of these individual boiler flows and the total flow (determined as just described) is a measure of the closure of the isobutane mass balance, and is discussed later.

Boiler Level-Liquid Entrainment Test. Concerns existed during the design review process that some liquid might be entrained in the vapor flow leaving the boilers. There were no mist pads or centrifugal separation devices in the boiler outlets. Only the distance separating the liquid interface from the outlets and plates blocking direct flow through the outlets prevented entrained liquid from leaving the boilers. Based on data available at that time, the provisions were thought to be sufficient.

Before performing the engineering tests, an attempt was made to determine if any liquid was being carried out of the boiler and if so, how it was related to liquid level and heat flux. When the turbine bypass line was open, the fluid was throttled to condenser pressure (essentially adiabatically, and therefore at constant enthalpy). If the boiler outlet state was two-phase, the low-pressure state would be superheated and pressure and temperature would allow determination of the state (unless there was a very large amount of liquid in the boiler outlet state). This allowed extrapolation back to the boiler outlet state and determination of that quality. Tests were run at 66 to $35 \%$ (130 to $70 \%$ of the bundle diameter) of the shell diameter at two different boiler pressures for each boiler. The design liquid level was $56.8 \%$ of the shell diameter. The results of these tests are shown in Figures 10 and 11. These curves show, for the high-pressure and low-pressure boilers, respectively, the amount of liquid entrained in the outlet flow as a function of boiler level for two different boiler pressures.

The boiler pressures were regulated with the same geothermal flow through the boilers. Consequently, the lower pressure represents a higher log mean temperature difference, and therefore, a higher vapor generation rate. The real variable influencing liquid entrainment is probably vapor velocity (or vapor volume flow rate). When the

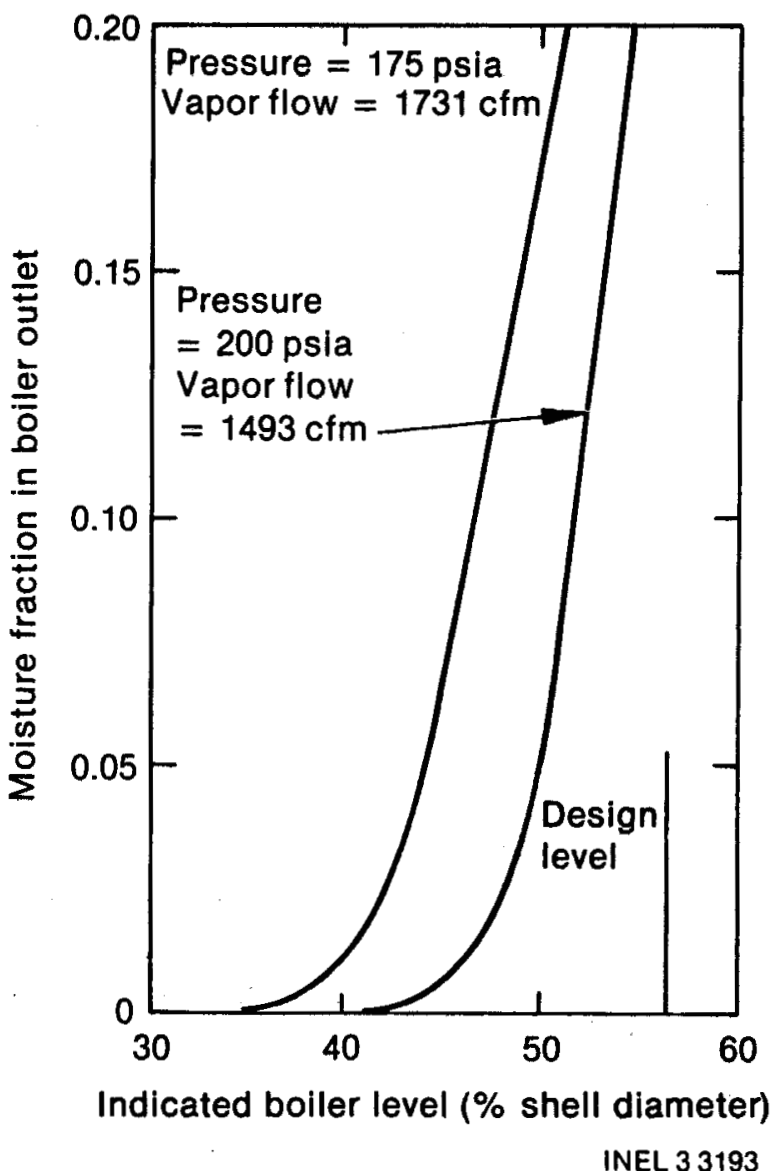

Figure 10. Low-pressure boiler entrainment tests. 


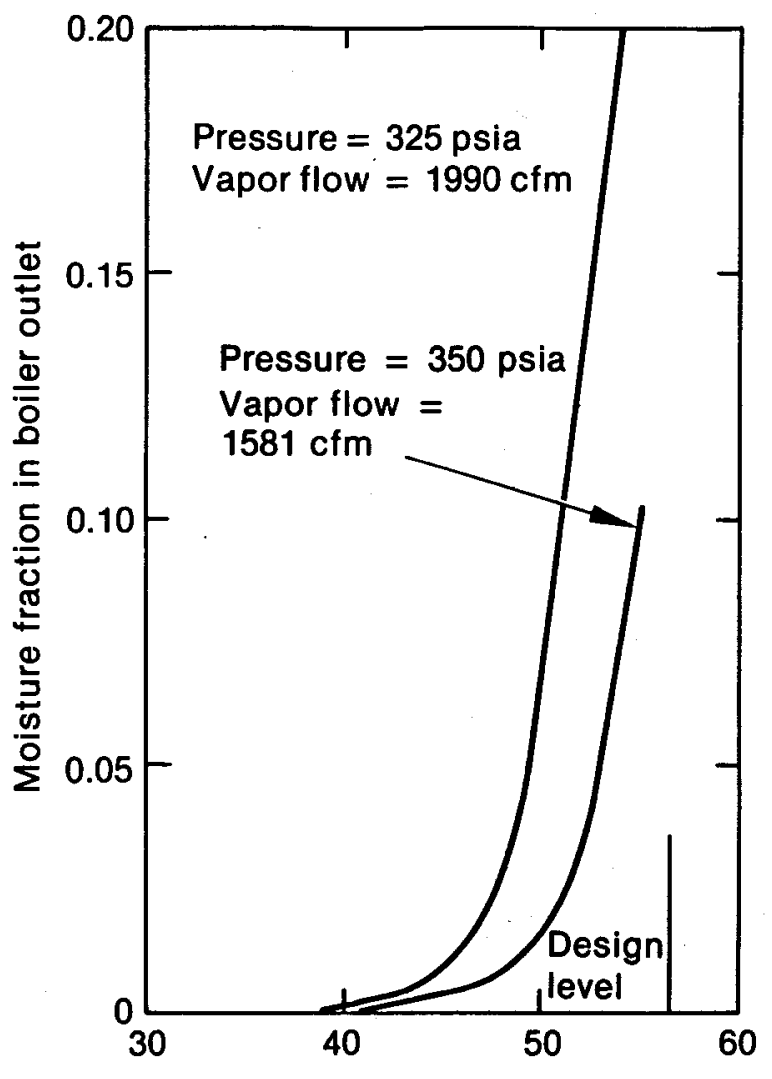

Indicated boiler level ( $\%$ shell diameter)

INEL 33208

Figure 11. High-pressure boiler entrainment tests.

test results were used to predict entrainment at test conditions, the interpolating/extrapolating variable used was measured vapor volume flow rate.

Interesting points to note are that for a given vapor generation rate, there appears to be a threshold liquid level below which no liquid entrainment is detected. Above this value, the amount of liquid entrained in the exit flow rose dramatically as liquid level was increased. At higher vapor generation rates, the threshold level was lower, but the curve has generally the same shape. Lack of similarity of the curves is most probably a result of the limited amount of data taken.

Although the two boilers are geometrically identical, correlations of liquid carryover with vapor velocity were not in agreement for the two boilers. This is because there are, additionally, fluid property effects (surface tension, liquid vicosity, liquid and vapor density). This correlation was not pursued with the limited amount of data available.
The results, as presented in Figures 10 and 11 , were used during data reduction to estimate boiler outlet qualities for all of the listed runs by interpolating/extrapolating the results at the particular boiler level with respect to measured boiler outlet vapor volume flow rate.

Assessment of Data Consistency. Experimental data from each of the individual tests were reduced in accordance with the method described earlier in this section. Figure 9 shows a schematic diagram of the system along with the location of all of the state points that were determined in the data analysis.

Table 5 gives a summary of the consistency of the results of all of the tests. This summary is in the form of deviations of mass and energy balances from perfect closure.

The geofluid and cooling water mass balances are each shown with two different mass flow rate measurements. The error quoted is the difference between these two values expressed as a percentage of the average. In the isobutane loop, averages were determined for the high-pressure boiler and low-pressure boiler flows as well as the combined flow as was discussed. The error in closure is the difference between the combined flow and the sum of the boiler flows expressed as a percentage of the combined flow. Note that with the exception of the geofluid, both positive and negative differences exist. All of the geofluid differences are negative, indicating that the measured flow into the system was always higher than the flow out of the system. For all of the tests, the average lack of closure of the mass balance was 2.8, 3.2, and $0.1 \%$ for the isobutane, geofluid, and coolant systems, respectively. These magnitudes indicate quite good agreement.

An overall energy balance (geofluid to coolant, including turbine and pump work), as well as energy balances for the individual heat exchangers, was made using the average mass flow rates. Table 5 shows the deviation from closure for each component for each test. Note that the overall energy balance has an average deviation of $1.2 \%$ which gives credence to the geofluid and cooling water flow rates. The average deviation for the individual heat exchangers are: 1.5, 1.7, 


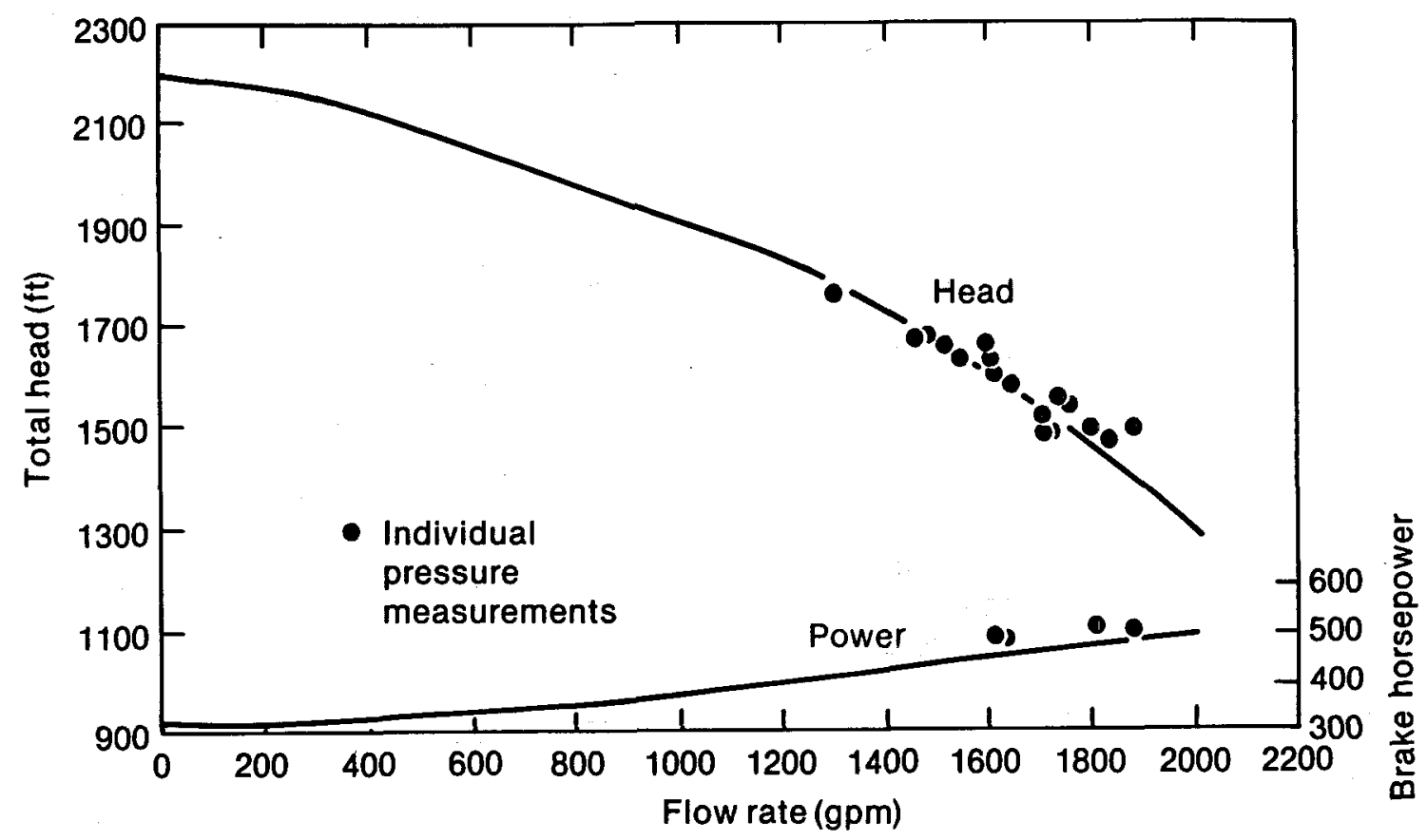

INEL 33212

Figure 12. Isobutane pump performance (Pump 101).

the corrected data compared closely with the vendor data. Figure 13 shows similar performance for Pump P-102 (Sensors PT 129, PT 131, FE 133). Note that this pump appears to be operating below the specified head for a given flow.

Figure 14 compares the average head produced by Pumps P-101 and P-102 with half of the total volumetric flow rate indicated (Sensor FE 278) downstream of both pumps. As shown, the comparison is similar to Figure 13 with the operational data falling below the vendor data.

A review of the isobutane flow rates around the loop for all of the runs indicated that the sum of the flow rates through Pumps P-101 and P-102 was consistently higher than the flow rate measured at other points in the loop. The difference averaged slightly over $6 \%$ for the cases where the turbine was powered, and slightly more than $13 \%$ for the thermal loop (turbine not powered) cases. Similarly, measurement of the total isobutane flow was quite close to the other indications of the isobutane flow. It is, therefore, felt that Figure 14 is a more accurate indication of the actual conditions for both pumps than are Figures 12 and 13. On this basis, the pumps pro- duce approximately $100 \mathrm{ft}$ (approximately $25 \mathrm{psi}$ ) less than the specified head at a given flow. This confirms the observation by the operations personnel that the pumps were not adequate to pump the required flow to the high-pressure boiler under this maximum geofluid flow condition. The original design did not include a very large safety margin.

As suggested by Figure 12 the power required to drive the pumps was quite close to that indicated on the pump curves at a given flow.

Figure 15 compares the head/flow test results for the geothermal pumps. The operational data fell below the vendor data when the upstream and downstream pressure sensor measurements (PT 882 and PT 889) were used, but matched the vendor data very closely when the differential pressure measurement (PT 885) data was used. The range on the pressure instrumentation is such that the differential pressure is thought to be a more accurate measurement than the individual pressure measurements. These pumps operated well during the test series. They had a quite large safety margin in the original design. 


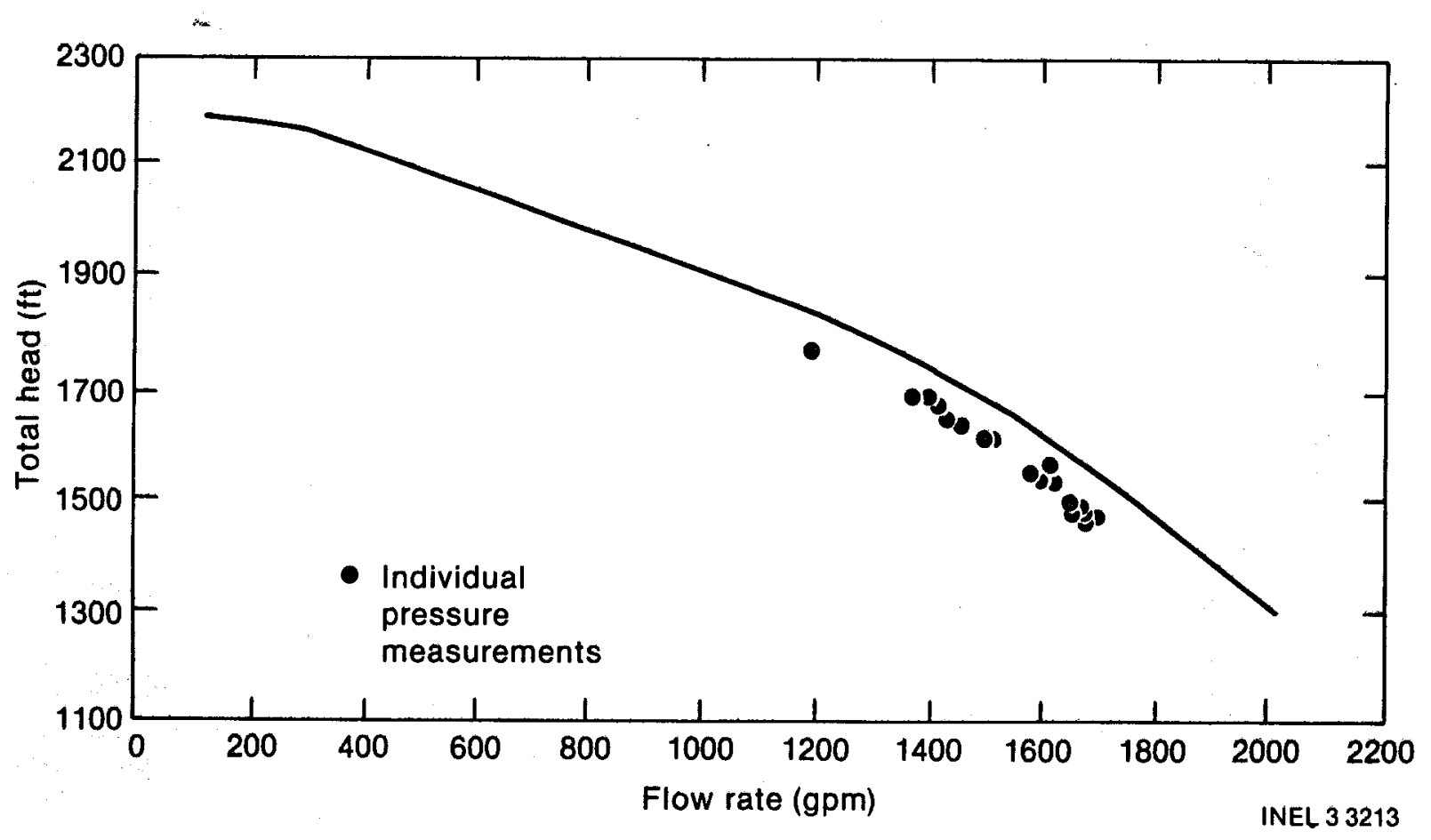

Figure 13. Isobutane pump performance (Pump 102).

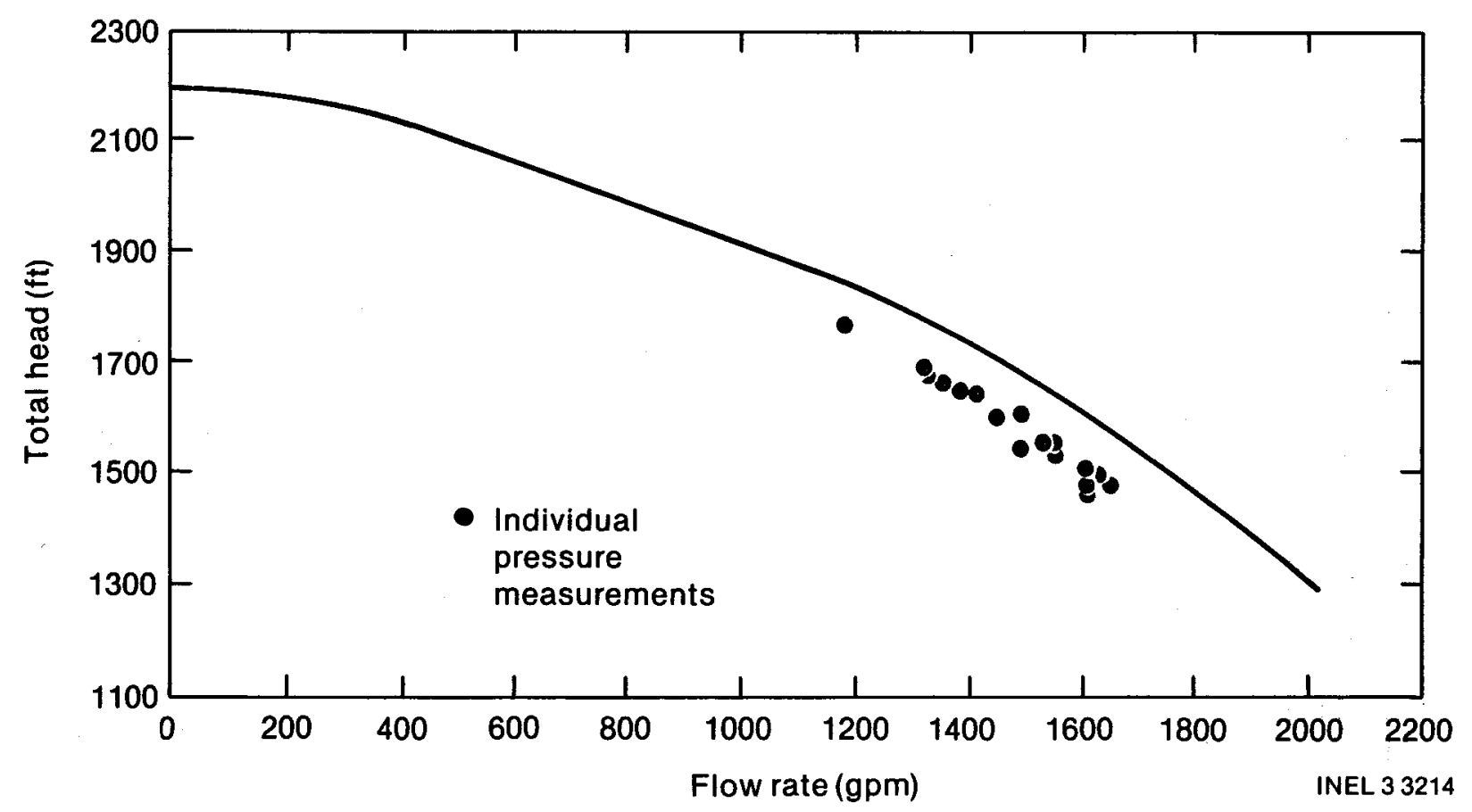

Figure 14. Isobutane pump performance-average flow. 
Figure 16 shows the performance of the cooling water pumps. The line represents the manufacturer's flow/head curve. Dots represent experimental data when only Pump P-901 was operating and the $\Delta$ 's represent data when only Pump P-902 was operating. Note that at the design flow rate of $7700 \mathrm{gpm}$, the head rise produced by the pumps was 25 to $40 \%$ lower than the manufacturer's value. This is probably due to improper installation of the pumps. The sump was not as deep as

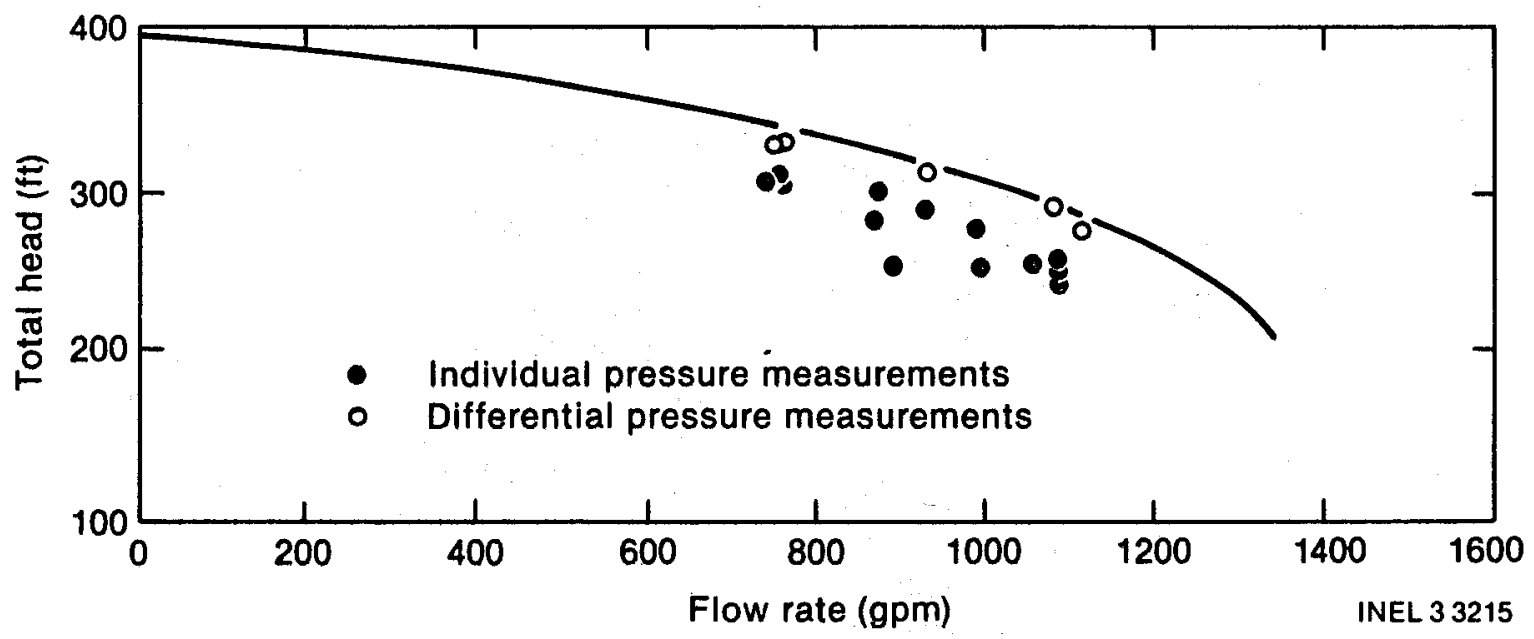

Figure 15. Geofluid pump performance.

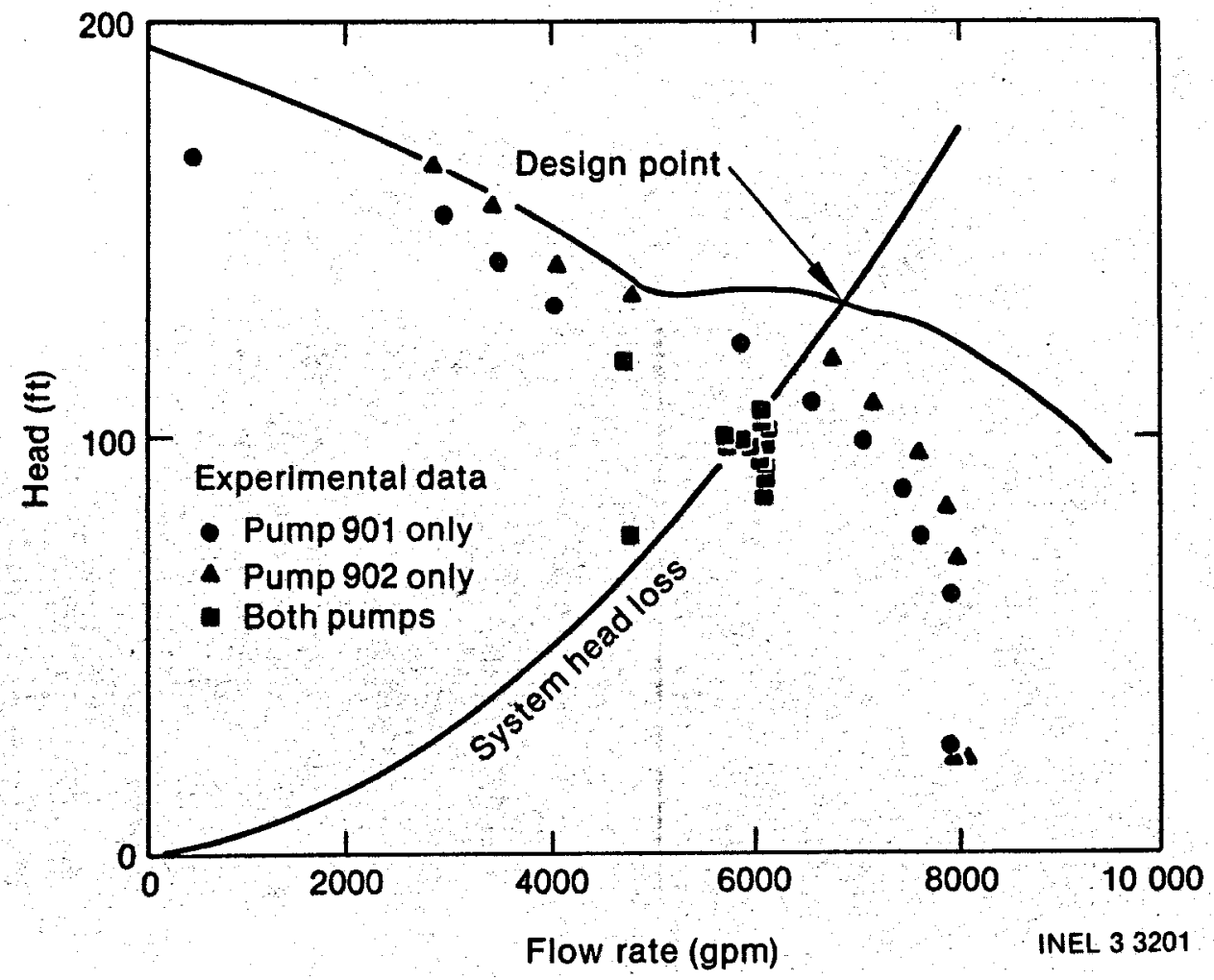

Figure 16. Cooling water pump performance. 
designed, requiring that the inlet strainers for each pump be cut off. It is felt that this caused additional pressure drop in the pump line. (Note that the discrepancies between the manufacturer's values and experimental measurements decrease with decreasing flow.)

The squares on Figure 16 represent the data taken when both pumps were running during the performance tests. For this plot, each pump was assumed to produce half of the total flow. When both pumps were operated, the deviation from the pump curve is approximately twice as large as it is when a single pump is operating. This would indicate that there was interference between the pumps or a flow restriction when the flow increases. Assuming that the pumps were working in accordance with the manufacturer's curve and the system flow resistance was as indicated with both pumps running, the flow produced by a single pump would be approximately $7200 \mathrm{gpm}$ as opposed to the observed flow of about $6000 \mathrm{gpm}$ as indicated by the intersection of the squares on Figure 16 with the system head-loss curve. The resulting impact on power production will be examined later.

\section{Turbine Performance}

Description of Turbine, Generator, and Instrumentation. The power in this system was produced by a turbine with two independent stages connected to a generator through a gearbox.

The turbine provided by the Elliot Company utilized the barrel compressor design. The barrel casing was fabricated with a solid outer shell and the inlets and exhaust nozzles were fabricated and welded to the outer shell. The expander end walls were one-piece construction and bolted to the outer casing on the vertical split. This type of casing enclosure was used because it is very easy to seal for high-pressure applications and also facilitates disassembly and reassembly after maintenance outages. A photograph of the turbine-generator assembly is included as Figure 17.

The rotor for this expander had two radial inflow wheels. Figure 18 shows a cross-sectional sketch of the turbine. The high-pressure flow entered the turbine on the left hand side, and

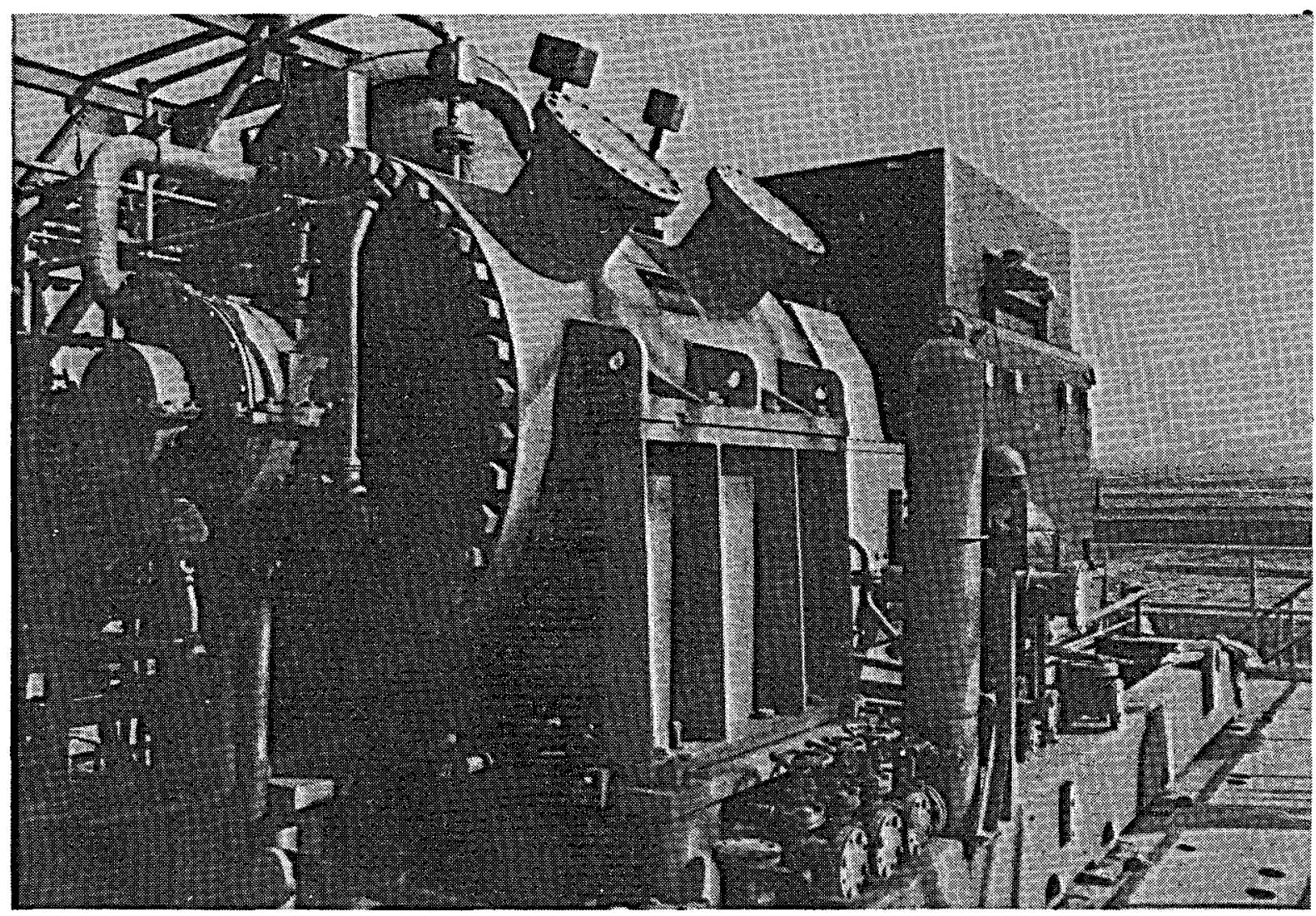

Figure 17. Turbine-generator assembiy. 


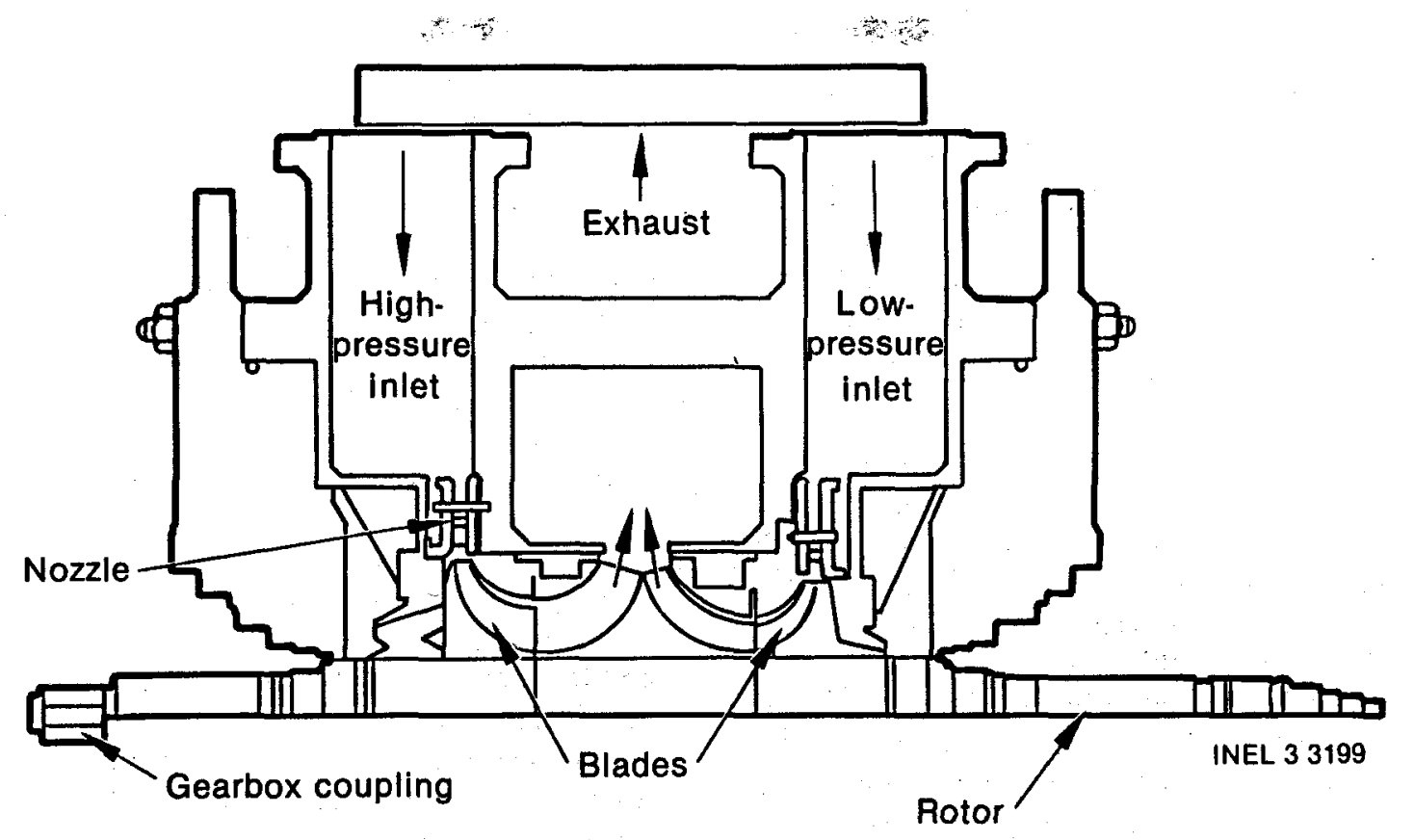

Figure 18. Radial inflow turbine cross section.

flowed through the nozzle section, the rotor, and a diffusion section before leaving at the center of the turbine. The low-pressure flow followed a corresponding path entering from the right-hand side. Because the flow from the low- and highpressure inlets were combined to a common exhaust connection, the aerodynamic thrust load of the unit was minimized. The radial wheels were fabricated and shrunk and keyed to a forged alloy shaft.

The manufacturer furnished performance predictions for the units including plots of:

1. Flow coefficient versus pressure ratio for each stage

2. Isentropic efficiency versus velocity ratio for each stage

3. Turbine mechanical losses versus speed

4. Generator losses versus speed and input power.

The power efficiency of the gearbox was stated to be 0.985 .

The turbine was instrumented with internal pressure and temperature sensors. Unfortunately, they did not read reliably enough to estimate stage efficiency of the independent stages and time limitations precluded repairing them.

This section explores two aspects of the turbine performance: the power produced and the flow through the turbine. Experimental results are compared with theoretical values.

Power Output Comparisons. A wattmeter was installed and monitored throughout the testing and the readings compared with calculated power from test data. In addition to the direct experimental measurement of power produced, calculations of the power using other measured values such as pressure temperatures and flow rates were made. Two of the methods of calculating power were: (a) the enthalpy drop from the measured inlet and outlet conditions, and (b) the enthalpy drop calculated from an isentropic expansion from the turbine inlet conditions to the outlet pressure was used together with the turbine manufacturer's design data to estimate generator output. The change in enthalpy multiplied by calculated isobutane loop mass flow rate gave the gross power to the turbine. In the latter case, the isentropic enthalpy drop was used to calculate a spouting velocity which was used to derive a turbine efficiency from the manufacturer's design data. From this calculated gross power, manufacturer's design data was used to estimate turbine mechanical losses, gearbox losses, and generator 
windage and electrical losses to calculate the net generator output. The results of these calculations are shown in Table 6 together with the generator power output indicated by the wattmeter. As shown, the power output calculated from the isentropic expansion and manufacturer's design data (Column 4) is generally higher than the measured value (Column 4 ) as obtained from the wattmeter.

As discussed previously, some moisture (isobutane droplets) entered the turbine inlet during most of the tests. In steam turbines, test data indicate that the efficiency of the turbine is degraded by the percentage of moisture in the turbine. The second column in Table 6 was produced by degrading the turbine efficiency by the estimated average moisture in the turbine. This resulted in reducing the average difference between the measured power (Column 4) and the calculated power assuming an isentropic expansion and the manufacturer's efficiency data from approximately 12 to $6 \%$.

The third column in Table 6 is the calculated power indicated by the enthalpy drop across the turbine using the indicated conditions on the inlet and outlet of the turbine. The calculated power output is generally higher than the wattmeter reading for most of the tests, however, not consistent enough to conclude that the wattmeter reading is low. Possible reasons for variations in the results will be discussed later.

Agreement among the various calculation methods is fairly good. Use of the pressure ratio and manufacturer's efficiencies gives a value which averages $9 \%$ above the expected readings. With the penalty for moisture, this number decreases to $4 \%$. Using the inlet and outlet state points, the deviation averages $8 \%$. An interesting point to note is that the experimental readings (Column 4) are from the computer readout, and when the panel meter reads $4.7 \mathrm{MW}$ (the maximum power reading), the computer reads a number $5 \%$ lower. Comparisons of Columns 2, 3 , and 4 in Table 6 suggests that the computer readout may indeed be 5 to $8 \%$ lower.

Turbine Inlet Throat Area. Operation of the plant at design flow rates of the geofluid loop required some throttling of the isobutane between the highand low-pressure boilers and the turbine to maintain boiler liquid level. Some effort was made to determine if this situation was the result of the stationary turbine inlet nozzles being installed so that the throat area was greater than design. It is general practice to adjust the nozzles after limited testing to "fine tune" their performance. Because of the limited operation of the plant, there was no time to do this.

Figure 19 shows measured flow versus turbine inlet pressure for the high-pressure turbine for several choked-throat conditions. Assuming the flow rate has a linear relationship with inlet pressure when the inlet nozzles were choked, the test flow data are slightly higher than values predicted using the design flow coefficient provided by the manufacturer. A similar comparison for the low-pressure turbine stage (Figure 20) shows the flow obtained from test data to be much higher, compared to the design point, than for the high-pressure stage.

Table 6. Calculated power from test data

\begin{tabular}{|c|c|c|c|c|}
\hline Test & $\begin{array}{c}\text { From Isentropic } \\
\text { Enthalpy Drop and } \\
\text { Turbine Vendor } \\
\text { Design Data } \\
\text { (kW) }\end{array}$ & $\begin{array}{c}\text { Efficiency Degraded } \\
\text { for Moisture in } \\
\text { Turbine } \\
\text { (kW) }\end{array}$ & $\begin{array}{c}\text { From Measured } \\
\text { Enthalpy Drop } \\
\text { Across Turbine } \\
(\mathrm{kW})\end{array}$ & $\begin{array}{c}\text { Indicated } \\
\text { Power from } \\
\text { Wattmeter } \\
(\mathbf{k W}) \\
\end{array}$ \\
\hline $1 \mathrm{~A}$ & 4468 & 4309 & 3947 & 4010 \\
\hline $3 \mathrm{C}$ & 3894 & 3719 & 3153 & 4195 \\
\hline 5BR & 3885 & 3686 & 4009 & 3475 \\
\hline $5 \mathrm{C}$ & 3367 & 3131 & 3192 & 3040 \\
\hline $6 \mathrm{R}$ & 3446 & 3317 & 3550 & 3265 \\
\hline $7 \mathrm{AR}$ & 4131 & 3392 & 4462 & 3835 \\
\hline 7BR & 3569 & 3450 & 4008 & 3280 \\
\hline $7 \mathrm{C}$ & 3223 & 2995 & 3233 & 2680 \\
\hline
\end{tabular}




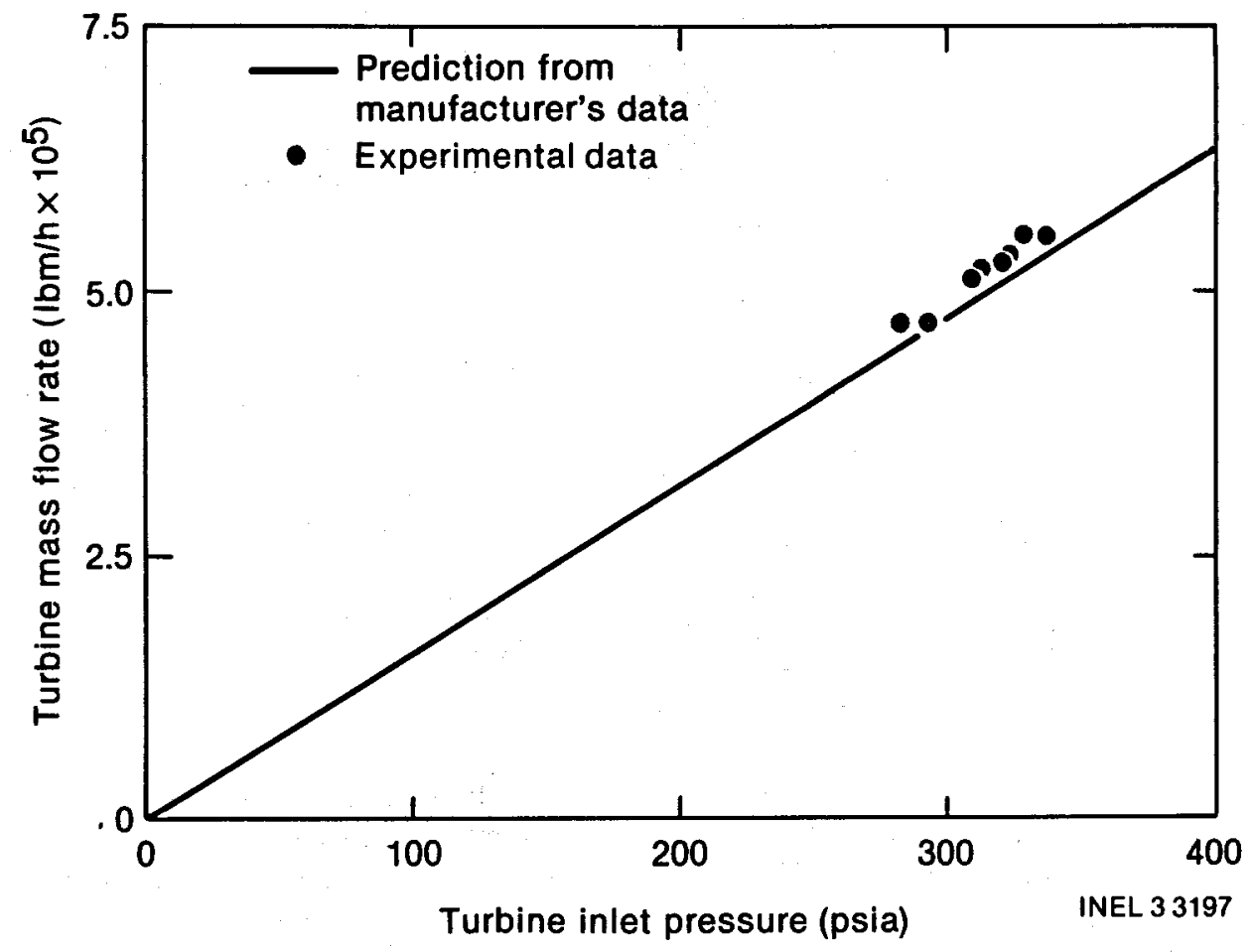

Figure 19. Flow in high-pressure turbine stage.

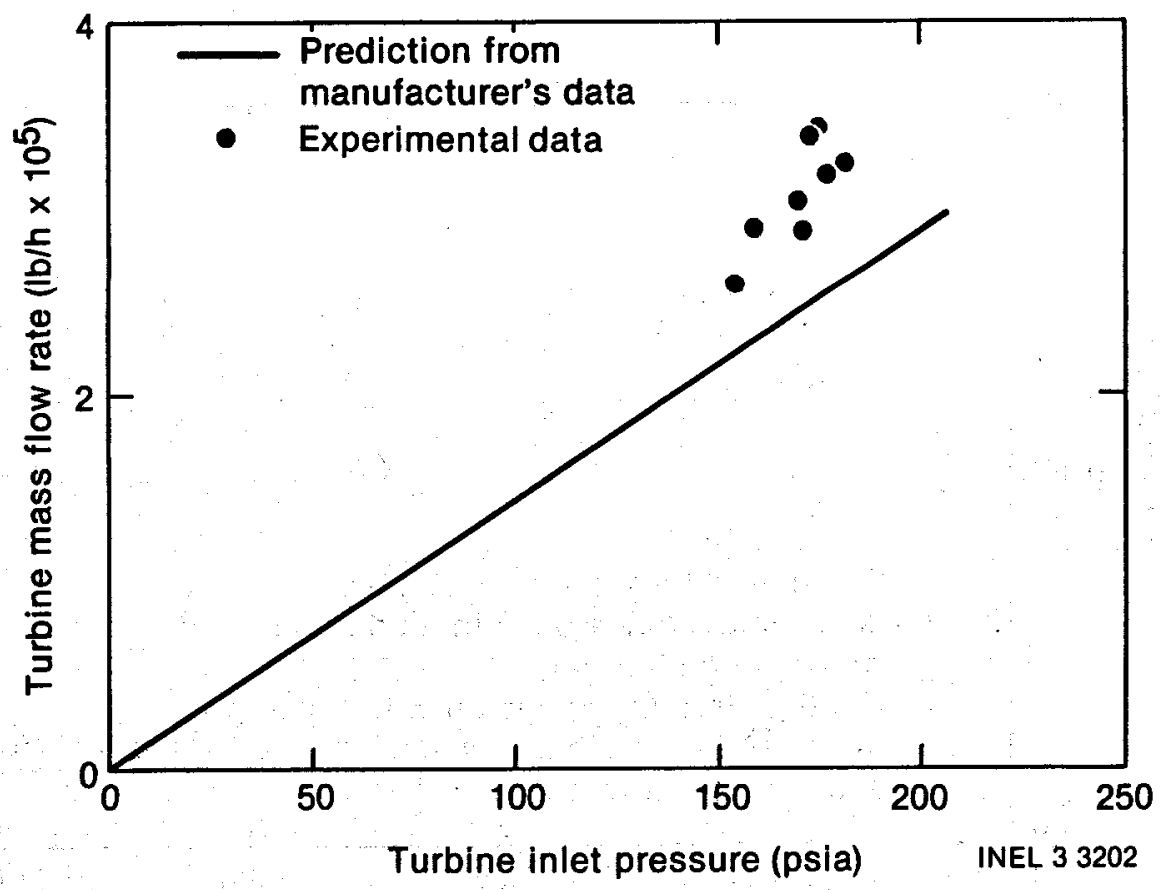

Figure 20. Flow in low-pressure turbine stage. 
As previously discussed, it believed that some moisture was entering the turbine for most tests, and the above comparison makes no correction for moisture. To get some estimate for the effective throat area that accounted for variations in mass flow rate, inlet pressure, and moisture for each of a number of test conditions, an isentropic expansion was calculated from the inlet conditions by calculating thermodynamic properties at successively lower pressures. At each reduced pressure, an expanded velocity was calculated. This process was continued until a maximum was achieved in the product of the density and velocity. This maximum was assumed to correspond to the fluid conditions at the throat of the inlet. This product was divided into the average calculated mass flow rate for each turbine to determine the effective inlet throat area (assuming a unity discharge coefficient).

Throat areas calculated in this way for eight cases are compared with the area specified by the manufacturer in Figure $\mathbf{2 1}$ for the high-pressure turbine, and Figure 22 for the low-pressure turbine. Two data points are indicated for each of the test conditions. The first calculated throat area assumes the liquid and vapor entering the inlet remain in both thermal and velocity equilibrium through the turbine. In actuality, the phases are not in equilibrium due to the saturation temperature lowering as the fluid expands through inlet nozzle and the finite time required to transfer heat between the phases. In addition, there would be some velocity slip between the phases.

In an effort to bound the throat area calculation without more detailed test data, a second calculation was made assuming the liquid and vapor phases were not in thermal equilibrium, but were at the same velocity. This assumes that the liquid entering the turbine inlet, remained at the same thermodynamic state and all the energy required to accelerate the fluid through the expansion was provided by the vapor. As shown, this second calculation resulted in a slightly smaller calculated effective throat area for each test.

Admittedly, this is not a rigorous nor a completely conclusive treatment of the expansion phenomena going through the turbine with the presence of moisture in the working fluid. The foregoing observations are presented as an indication that the inlet nozzle areas of the turbine as installed were possibly larger than designed for (about 3\% for the high-pressure nozzles and 10\% for the low) resulting in some degradation of turbine efficiency.

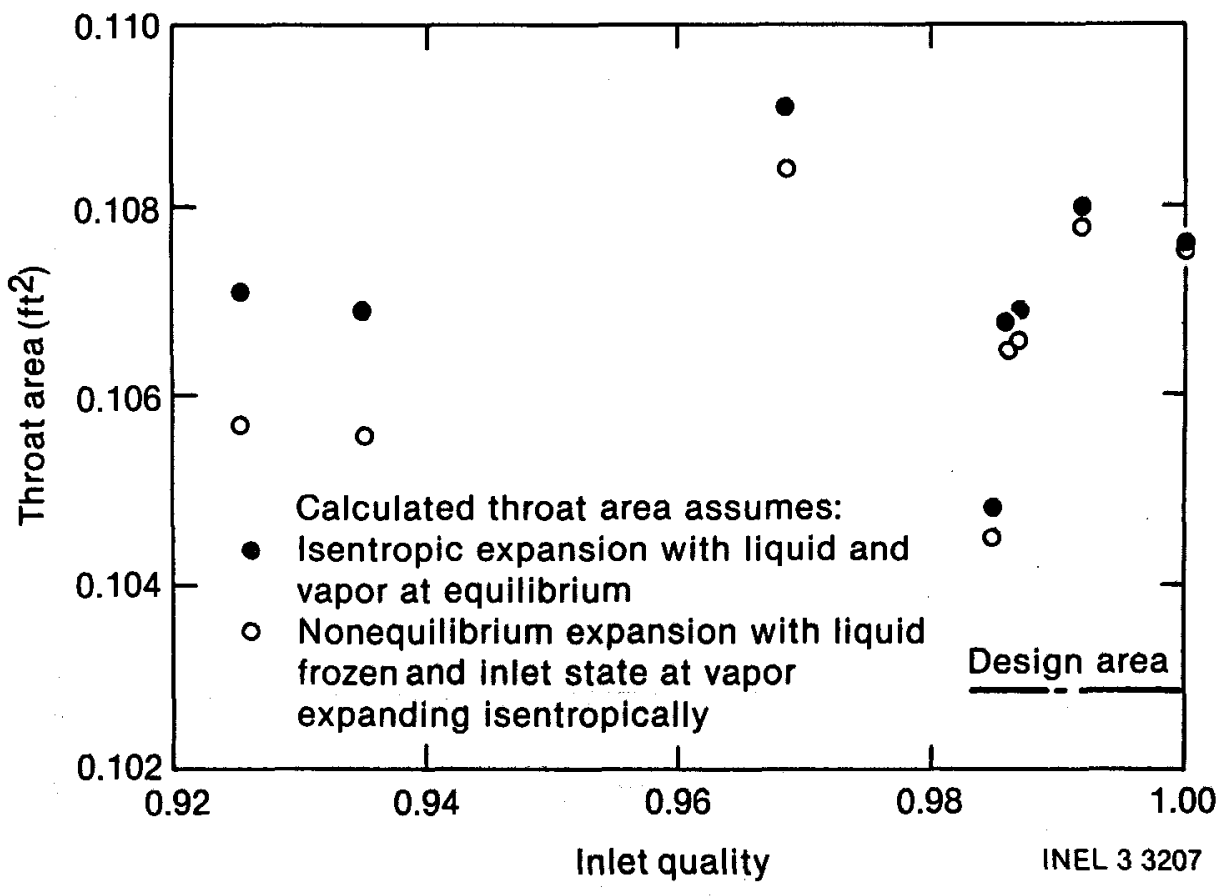

Figure 21. Calculated throat area for high-pressure turbine stage. 


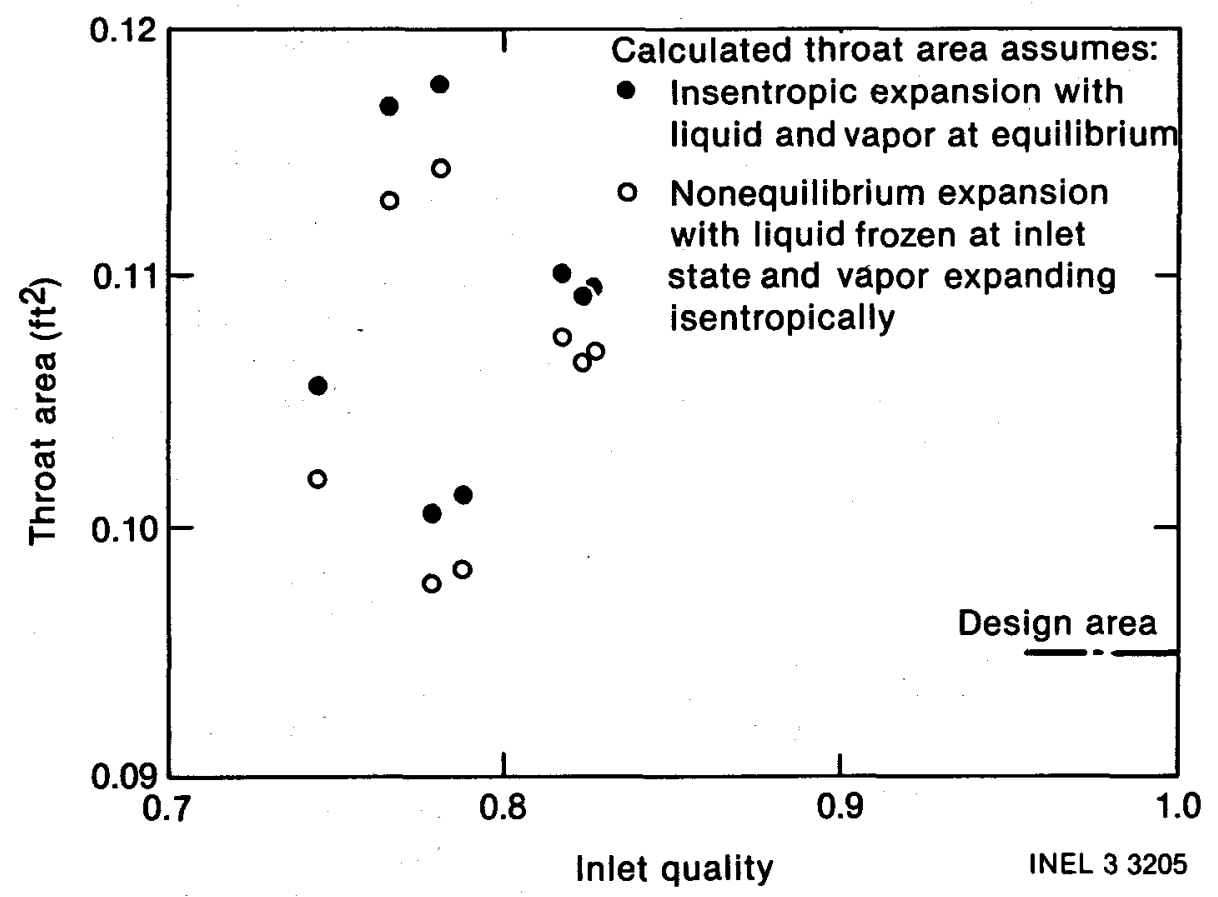

Figure 22. Calculated throat area for low-pressure turbine stage.

\section{Cooling Tower Performance}

Introduction. The heat rejected from the power cycle was ultimately dissipated to the atmosphere through a wet cooling tower. The tower consisted of two 40- by 70-ft cells, each equipped with a fan driven by an 80 -hp motor. The tower was $53 \mathrm{ft}$ high. At design conditions, it was to cool $15,798 \mathrm{gpm}$ of water from $96.3^{\circ} \mathrm{F}$ to $75^{\circ} \mathrm{F}$ when the ambient wet bulb temperature was $65^{\circ} \mathrm{F}$. The manufacturer gave a value of the cooling tower characteristic $(\mathrm{KaV} / \mathrm{L})$ for the tower to be $2.07 \mathrm{lbm} /{ }^{\circ} \mathrm{F} / \mathrm{Btu}$ at design conditions. ${ }^{\mathrm{a}}$ The manufacturer also supplied curves for 90,100 , and $110 \%$ of design water flow for cold water temperature as a function of ambient wet bulb temperature and range.

Actual Cooling Tower Performance. For each run in the test series, the cooling water inlet and outlet temperatures, flow rate and ambient wet and dry bulb temperatures were measured. The cooling water flow rate was around $77 \%$ of the design value because of the inadequacy of the cooling

a. Number of diffusion units (see Reference 8) for standard cooling tower analysis. $\mathrm{K}$ is the overall mass transfer coefficient in units $\mathrm{lb} / \mathrm{h}\left(\mathrm{ft}^{2}\right)(\mathrm{lb} / \mathrm{lb})$, $a$ is the surface of the fill per unit volume $\left(\mathrm{ft}^{2}\right) /\left(\mathrm{ft}^{3}\right), V$ is the tower volume in $\mathrm{ft}^{3}$ and $\mathrm{L}$ is the liquid loading in $\mathrm{lb} /(\mathrm{h})$. water pumps. This meant that the performance inferred from the manufacturer's curves had to be extrapolated from the 100 and $90 \%$ flow values. Figure 23 shows the relationship between the measured values of tower outlet water temperature and the predictions based on the manufacturer's curves. The measured values are much higher than the predicted values, ranging from 3.0 to $35.9^{\circ} \mathrm{F}$ higher. The average difference is $12^{\circ} \mathrm{F}$ if the two extreme points (predicted temperature of $47^{\circ} \mathrm{F}$ ) are excluded. This is an extreme extrapolation so to test its accuracy, a separate calculation was made using Merkel's theory (see Reference 8) and the design $\mathrm{KaV} / \mathrm{L}$ of 2.07 as specified by the manufacturer. These values essentially reproduced the extrapolated values (being between 1 and $3^{\circ} \mathrm{F}$ higher than the extrapolated values).

The most probable reason for this deviation, shown in Figure 23, is that the calculation assumes that the fans were set on the high position. Although detailed records of fan settings are not complete there is ample evidence that this was not the case for a large number of tests; because of problems associated with the water treatment system, the operators ran the fans at low speed for many of the tests. The lower fan settings caused a large penalty in condenser pressure and therefore, in plant output. This effect is quantified in a later 


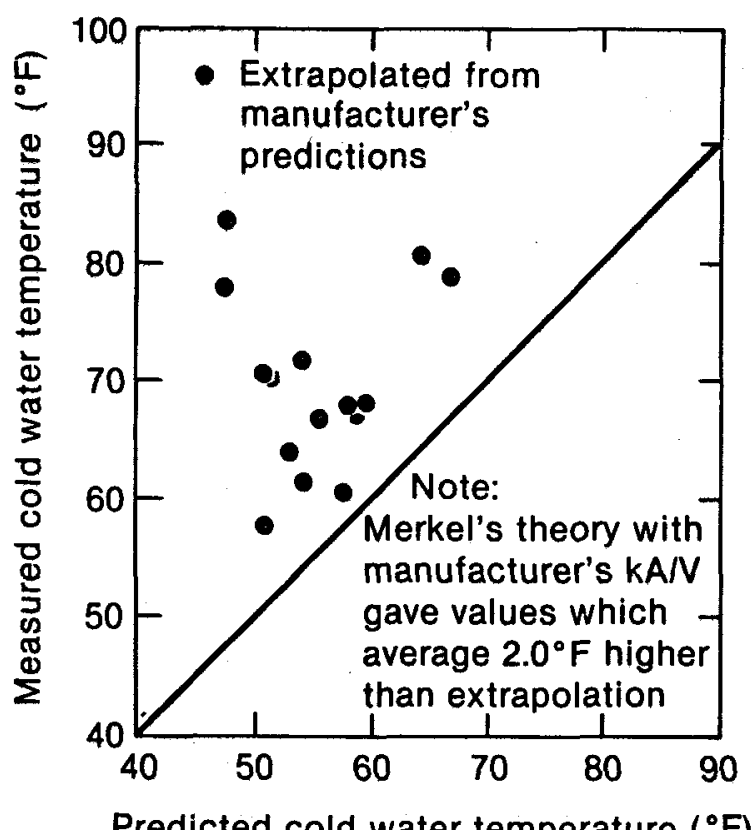

INEL 33211

Figure 23. Cooling tower performance.

section. This experience points out the need for attention to apparently routine details of record maintenance.

Heat Exchanger Performance. The results of an analysis of the data from the performance evaluation tests summarized earlier are presented to study the performance of the heat exchangers during system operation. Originally, it was planned to obtain the heat exchanger fouling resistances as a function of time during the period of operation by comparison of the (clean) performance of each unit prior to significant testing against the performance throughout the first year or two of operation.

However, two factors precluded reducing the data in this manner and required a somewhat less rigorous approach to evaluate the performance. First, the initial sets of data were taken well after startup and do not accurately represent the exchangers in an absolutely "clean" state. In fact, there is an indication that the units may have suffered some fouling during and after the hydrostatic testing and inactive period prior to the thermal tests. Although this occurrence may be prototypical of an actual field installation, it means that an accurate baseline of the "clean" performance was not available so that later performance changes could not be attributed totally to fouling alone; a difference in performance could also indicate that the "as built" performance was not equal to that specified by the heat exchanger vendor.

Second, instead of testing the plant and equipment over a period of several years as originally planned, the test data was only obtained over a period of about one month. This short test period made it almost impossible to establish a trend of fouling versus time, and indeed, the thermal resistances showed no appreciable trends with time.

Thus, the performance evaluation was reduced to obtaining an equivalent fouling resistance for each unit that would match the performance as exhibited by the test data. This equivalent fouling resistance is used as an indication of relative performance, e.g., if the resultant fouling required for reproducing a test condition is equal to zero, the unit either was not fouled, or, if it was fouled, the as-built performance was better than specified. Or, in other words, the equivalent fouling resistance is an indication of the deviation in performance of each heat exchanger from the clean performance claimed by the manufacturer.

The performance of each heat exchanger for the various test conditions was evaluated by use of the proprietary Heat Transfer Research, Inc. (HTRI) computer codes. The members of HTRI are heat exchanger manufacturers, architect-engineering firms, and heat exchanger users in industry. Hence, the benefits of the data obtained using HTRI codes and other information will benefit the heat exchanger industry and thus the future design of geothermal heat exchangers. These codes are available to EG\&G Idaho as a member company and consist of shell-and-tube, condenser, and boiler programs used in a rating mode for this study. The approach used was to input the measured fluid temperatures and flow rates, and then to vary the required fouling resistance so that the heat duty matched that from the test data. It was assumed that the manufacturer's performance evaluation for each unit was correct; if the HTRI prediction of performance did not match the manufacturer's for the conditions representing those in the design specification, the difference was supplied to all the test evaluation runs so that the resultant equivalent fouling resistance is referenced to the performance specified by the respective heat exchanger manufacturer. 
Condenser. The isobutane condenser, manufactured by Industrial Fabricating Co., was a splitflow type with two inlet nozzles in the top of the shell and three outlet nozzles at the bottom. It is shown in a schematic drawing in Figure 24. For simplicity, this figure does not show the baffles in the condenser shell and only one tube is shown for each tube pass rather than the entire tube bundle. The shell side condensing fluid was baffled with vertical segmental baffles and flows downward across the tubes. There were two coolant passes on the tube side of the exchanger.

The manufacturer's data sheet shows that the condenser was designed for $7,652,000 \mathrm{lb} / \mathrm{h}$ of cooling water entering at $75^{\circ} \mathrm{F}$ and leaving at $95^{\circ} \mathrm{F}$, and $934,000 \mathrm{lb} / \mathrm{h}$ of isobutane entering as vapor at $166.7^{\circ} \mathrm{F}$ and leaving with $4^{\circ} \mathrm{F}$ of subcooling at $101^{\circ} \mathrm{F}$. The condensing temperature was $105^{\circ} \mathrm{F}$ (this represents the thermal loop performance of the system). The heat exchanged at these conditions was $152,800,000 \mathrm{Btu} / \mathrm{h}$ with a mean temperature difference (mtd) of $18.18^{\circ} \mathrm{F}$ and a total heat transfer surface area of $56,996 \mathrm{ft}^{2}$. This resulted in an overall heat transfer coefficient of $151.4 \mathrm{~h} \mathrm{ft}^{2}{ }^{\circ} \mathrm{F} / \mathrm{Btu}$. Fouling resistances assumed for design were $0.0005 \mathrm{~h} \mathrm{ft}^{2}{ }^{\circ} \mathrm{F} / \mathrm{Btu}$ for the shell (isobutane) side and $0.001 \mathrm{~h} \mathrm{ft}^{2}{ }^{\circ} \mathrm{F} / \mathrm{Btu}$ for the tube (cooling water) side, both referenced to their respective areas.

The design operating pressures were $65.6 \mathrm{psig}$ on the shell side and $40 \mathrm{psig}$ on the tube side with pressure drops of $1.0 \mathrm{psi}$ on the shell side and $10.0 \mathrm{psi}$ on the tube side.

Baseline Performance-Before analyzing the data from the tests of heat exchangers, a baseline run was made for the condenser using the design specification temperatures and flows. This was done to obtain an independent predicted performance of the as-built unit using the HTRI condenser code for comparison with the manufacturer's predictions. It is emphasized that this only compares the two predictive methods and in no way indicates the actual as-built performance of the condenser. As mentioned previously, the as-built performance would ideally be obtained by analyzing test data from a "clean" unit; this was not possible in the case of the Raft River equipment.

The condenser was analyzed using the CST-1 Mod 2.0 computer code written by HTRI. CST-1 cannot be used to analyze a condenser with two inlets and three outlets directly so the condenser was divided in half, making a smaller unit with one inlet and two outlets which could be run. The shell side flow rate was cut in half, and the inlet and outlet temperatures of the coolant were linearly interpolated from the actual values. The inlet and outlet temperatures of both fluids and the flow rates were input into the code, together with the geometrical specifications of the condenser. Water properties were obtained from a built-in subroutine within the computer code CST-1; isobutane thermodynamic properties and transport properties were obtained as discussed earlier.

The rated performance of the condenser as predicted by CST-1 was about $3.4 \%$ less than that stated by the manufacturer for the design conditions; this was considered excellent agreement. The shell side pressure drop predicted by CST-1 was about 0.99 psi versus 1.00 psi by the manufacturer, while the tube side pressure drop from

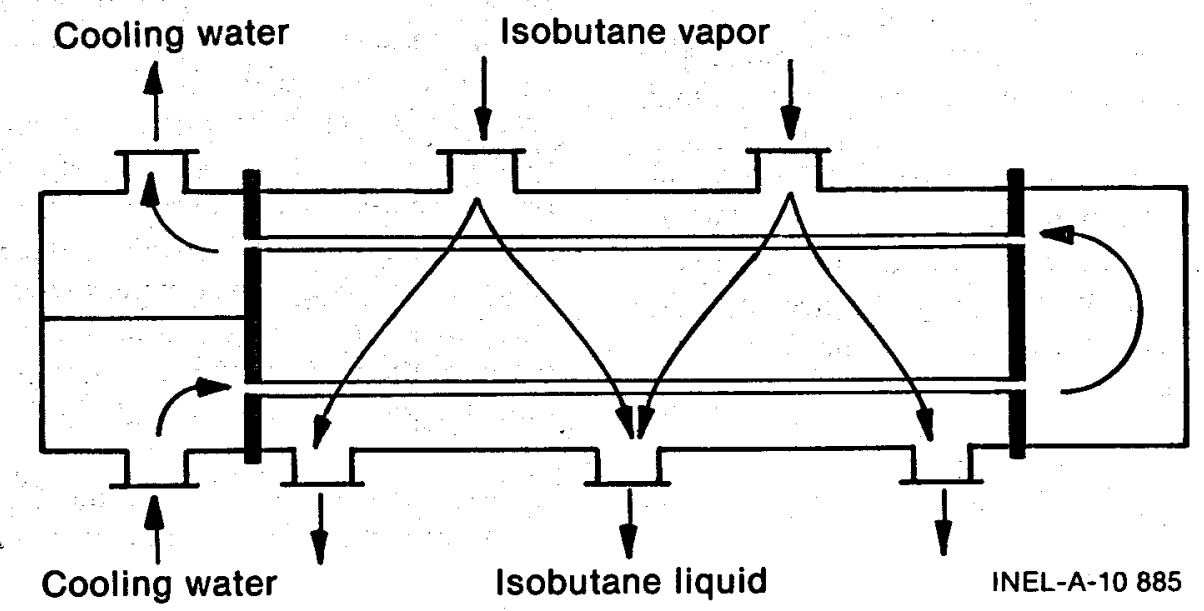

Figure 24. Isobutane condenser. 
CST-1 was 6.01 psi versus the manufacturer's value of $5.0 \mathrm{psi}$. This again is good agreement. Thus, a method is available to compare predicted ions both at design and off-design to actual measured performance.

In-Service Performance-Having established the predicted baseline performance of the condenser, the in-service performance can now be compared with the baseline. This was done by determining the effective total (inner and outer) fouling resistance that would be required for the predicted baseline performance to match the observed performance of the condenser for 11 representative test runs, spanning the entire time period of the tests. The manufacturer's predictions were used as the base case by adjusting the CST-1 overall heat transfer coefficient by the $3.4 \%$ difference when calculating the fouling resistance. The equivalent fouling resistance $r_{e q}$, was calculated by

$r_{\text {eq }}=\frac{1}{0.9665 U_{r}}-\frac{1}{U_{0}}$

where

$$
\begin{aligned}
& U_{r}=\text { required overall coefficient }(B t u / h \\
& \mathrm{ft}^{2 \circ} \mathrm{F} \text { ) } \\
& \mathrm{U}_{\mathrm{o}}=\text { clean overall coefficient }\left(\mathrm{Btu} / \mathrm{h} \mathrm{\textrm {ft } ^ { 2 }}\right.
\end{aligned}
$$

The CST-1 code bases its results on either the hot fluid or the cold fluid heat duty. Since the isobutane heat duty seemed to vary more than that of the cooling water, it was decided to use the cold fluid heat duty for the calculations. The difference in performance from design is expressed as the difference between the effective fouling resistance needed to match the test performance and the design fouling resistance, normalized by the design overall resistance. This parameter is expressed by

$$
\text { P.D. }=\frac{{ }^{r} e^{-r_{f, d e s}}}{r_{t, \text { des }}}
$$

where

$$
\begin{aligned}
& \text { P.D. }=\text { performance decrease } \\
& \mathrm{r}_{\text {eq }}=\begin{array}{l}
\text { equivalent fouling resistance, } \\
\mathrm{h} \mathrm{ft}^{2}{ }^{\circ} \mathrm{F} / \mathrm{Btu}
\end{array} \\
& \mathrm{r}_{\mathrm{f}, \text { des }}=\begin{array}{l}
\text { design fouling resistance }= \\
0.001784 \mathrm{ht}^{2}{ }^{\circ} \mathrm{F} / \mathrm{Btu} \text { (based } \\
\text { on outside area) }
\end{array} \\
& \mathrm{r}_{\mathrm{t}, \text { des }}=\begin{array}{l}
\text { design total resistance }= \\
\mathrm{t}, \text { des }
\end{array} \\
& \mathrm{U}_{\mathrm{t}, \text { des }}=140.09 \mathrm{Btu} / \mathrm{h} \mathrm{ft}^{2} /{ }^{\circ} \mathrm{F} .
\end{aligned}
$$

Thus, the apparent difference from design fouling is shown as a fraction of the total thermal resistance at design conditions. It is felt that this is a better way to present the results than to divide the difference in fouling resistance by the design fouling value because: (a) the equivalent fouling resistance includes not only actual system fouling but also any deviation between specified and "asbuilt" performance of a given unit and (b) as mentioned previously, the primary emphasis of this study was to investigate deviation of components from their specified performances.

Figure 25 shows the performance of the condenser for 11 tests that span the entire test period. The solid circles show the condenser performance. Results from the other heat exchangers are shown on the same figure for comparison and are discussed in subsequent sections. The results indicated an actual performance about $24 \%$ worse than design. Note that the apparent fouling resistance was $0.0035 \mathrm{~h} \mathrm{ft}^{2}{ }^{\circ} \mathrm{F} / \mathrm{Btu}$ compared with the design values of 0.001784 (based on the outside area). This is a $96 \%$ increase over design fouling, but since fouling accounts for only $25 \%$ of the total thermal resistance of design, it translates into the $24 \%$ increase quoted above.

Visual inspection of the inside of the condenser tubes confirmed that there were deposits on these surfaces which could have accounted for this performance degradation. 


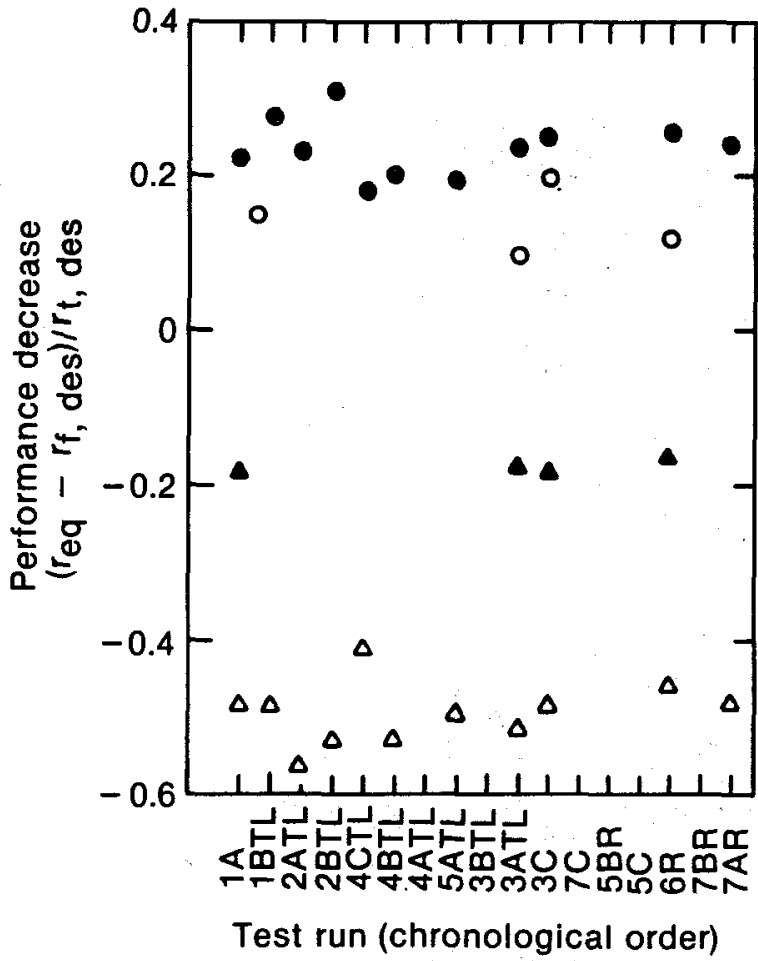

- Condenser $\left(r_{\mathrm{f}, \mathrm{des}}=0.001784 \mathrm{ft}^{2} \mathrm{~h}^{\circ} \mathrm{F} / \mathrm{Btu}\right.$, $\mathrm{U}_{\mathrm{des}}=140.1^{\left.\mathrm{Btu} / \mathrm{ft}^{2} \mathrm{~h}^{\circ} \mathrm{F}\right)}$

- High boiler $\left(r_{\mathrm{f}, \mathrm{des}}=0.00231 \mathrm{ft}^{2} \mathrm{~h}^{\circ} \mathrm{F} / \mathrm{Btu}\right.$, $\mathrm{U}_{\text {des }}=296.3^{\left.\mathrm{Btu} / \mathrm{ft}^{2} \mathrm{~h}^{\circ} \mathrm{F}\right)}$

- Low boiler ( $r_{\mathrm{f}, \mathrm{des}}=0.00231 \mathrm{ft}^{2} \mathrm{~h}^{\circ} \mathrm{F} / \mathrm{Btu}$, $\left.\mathrm{U}_{\text {des }}=254.4 \mathrm{Btu} / \mathrm{ft}^{2} \mathrm{~h}^{\circ} \mathrm{F}\right)$

$\triangle$ High preheater $\left(r_{f, d e s}=0.00608 \mathrm{ft}^{2} h^{\circ} \mathrm{F} / \mathrm{Btu}\right.$, $\mathrm{U}_{\text {des }}=90.77 \mathrm{Btu} / \mathrm{ft}^{2} \mathrm{~h}^{\circ} \mathrm{F}$ )

INEL 33210

Figure 25. Measured heat exchanger performance relative to manufacturer's design.

Tube Wall Temperatures-In addition to the measurements of the flow parameters into and out of the condenser, 32 temperature sensors were installed on five tubes in the condenser to measure the tube wall temperatures during operation. Figure 26 shows the tubes that were instrumented; axial locations are all in the half of the condenser that includes the tube side flow turnaround plenum and are detailed in the plots shown later.

Because CST-1 calculates the performance on an incremental basis, tube wall temperature distributions in the exchanger are available for comparison with the test data. Figures 27 through 29 show a comparison of the measured data with the CST-1 predictions for the first two tests (1A and $1 \mathrm{~B}$ ) and the final test (7A), thus spanning the entire test period. The abscissa in these plots is equivalent to distance along the tube side flow path; the -20-ft location is equivalent to the midpoint of the condenser in the first (lower) tube pass, the 0 location is the tube pass turnaround, and the $+20-\mathrm{ft}$ location is equivalent to the midpoint of the condenser in the second (upper) tube pass. Keep in mind that the shell side flow is cross flow downward. The upper and lower curves shown are the outer surface temperatures of the fouling layers along the tube pass for the equivalent fouling layer thickness presented in the previous section. The tube wall temperature is expected to fall somewhere between these two curves, depending on the relative thickness of each fouling layer.

The data points are shown as symbols on the figures for each of the $\mathbf{3 2}$ temperature sensors. For Test $1 \mathrm{~A}$ the tube wall temperatures generally follow the temperature of the inner foulant surface; this may indicate that the inner fouling layer is thin. Test 1BTL shows much the same trend, while in the last test, 7AR, the data is somewhat more centered between the surface temperatures. Because the total fouling resistance is relatively constant for these three runs, the data shift implies a shift in relative fouling layer thickness between the inner and outer layers. This is physically not probable and is more likely due to other factors as discussed later.

The peaks in the outer surface temperatures and test data are a result of the flow from the isobutane inlet nozzle located at about $\pm 10 \mathrm{ft}$ on the abscissa. As expected, the upper tubes show more of a response to the impingement than those deeper in the bundle. This effect is primarily due to the high-velocity inlet vapor impinging on the tubes and creating a higher film coefficient; secondarily, the vapor temperature is higher in the upper reaches of the bundle.

Although positive conclusions cannot be reached without good data from the condenser in the clean state, examination of the plots shows some general characteristics, which might explain the condenser tube wall temperatures as measured. Refer to the results for Test IA and 7AR, the first and last runs, respectively.

First, it is postulated that the as-built performance of the unit is somewhat poorer than that 


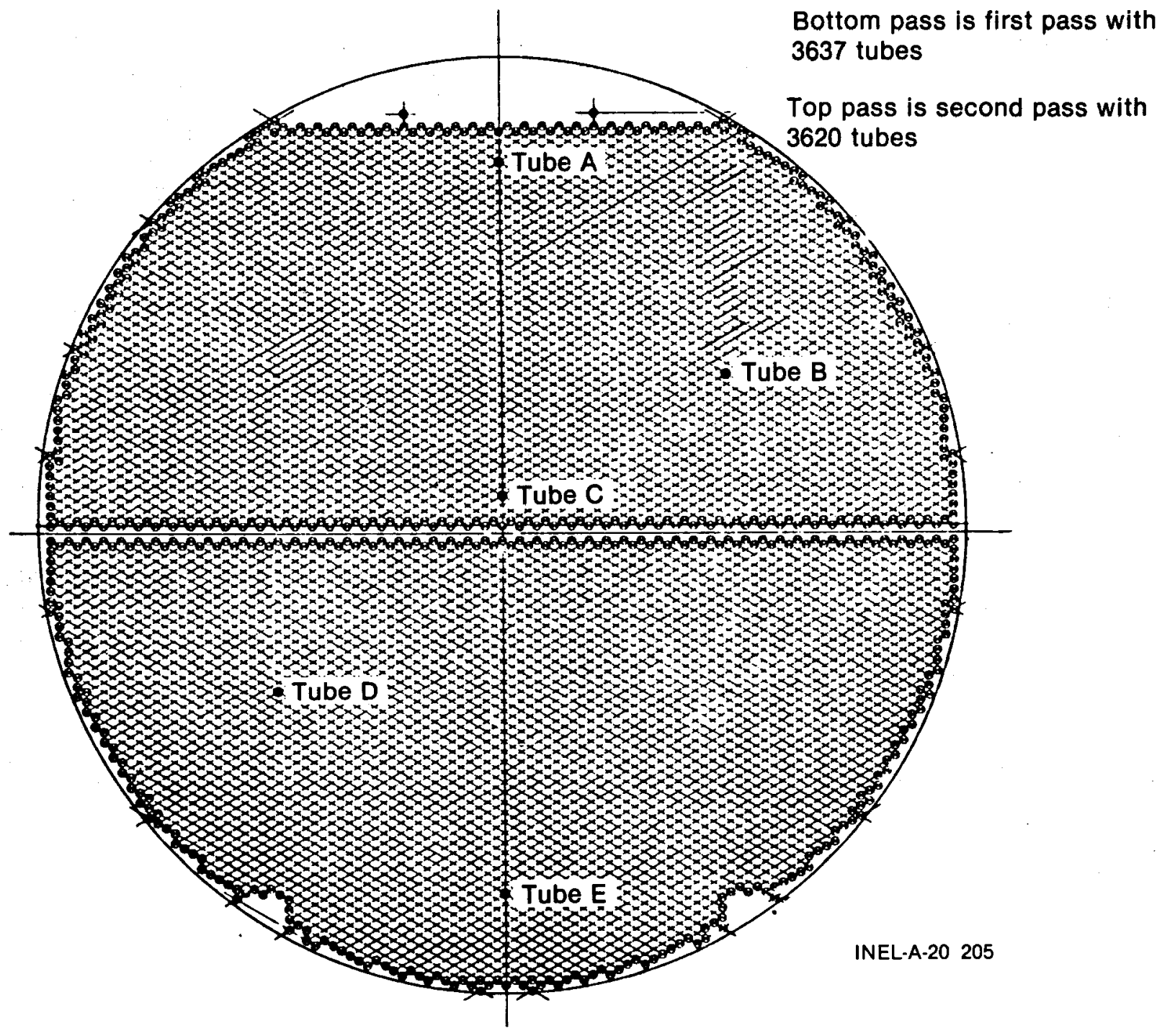

Figure 26. Location of instrumented tubes in the condenser.

shown; in particular, the shell side condensing coefficient is less than that used in the analyses, possibly due to noncondensable side effects. If this is true, then the portion of the equivalent fouling resistance due solely to fouling will be less than the total presented previously, and the upper curve on the figures will move down closer to the lower one since more of the total temperature drop will occur in the shell side film. It is postulated that the shell side surface temperature should be close to the upper data points in the figure.

Next, it is postulated that most of the remaining small amount of fouling is on the inside of the tube, and that it may build up with time. This is why the wall temperature is farther from the inner surface temperature in Test $7 \mathrm{~A}$, the last run.
Examination of the tube wall temperature peaks near the nozzle inlet shows another reason for assuming little fouling on the outside and most on the inside of the tubes. The tube side film coefficient is about 2 to 4 times as great as the shell side coefficient. This would tend to lock the wall temperature closer to the coolant temperature than to the vapor temperature. Even if the film coefficient on the vapor side increases by a factor of 2 to 4 on the vapor side due to jetting, the wall temperature would only move to about halfway between the vapor and the coolant temperature if the walls were unfouled or fouled equally. If the fouling layer were mostly on the outside, the wall temperature would fall even closer to the coolant temperature. However, if most of the fouling occurred on the inside of the tube wall, the fouling 


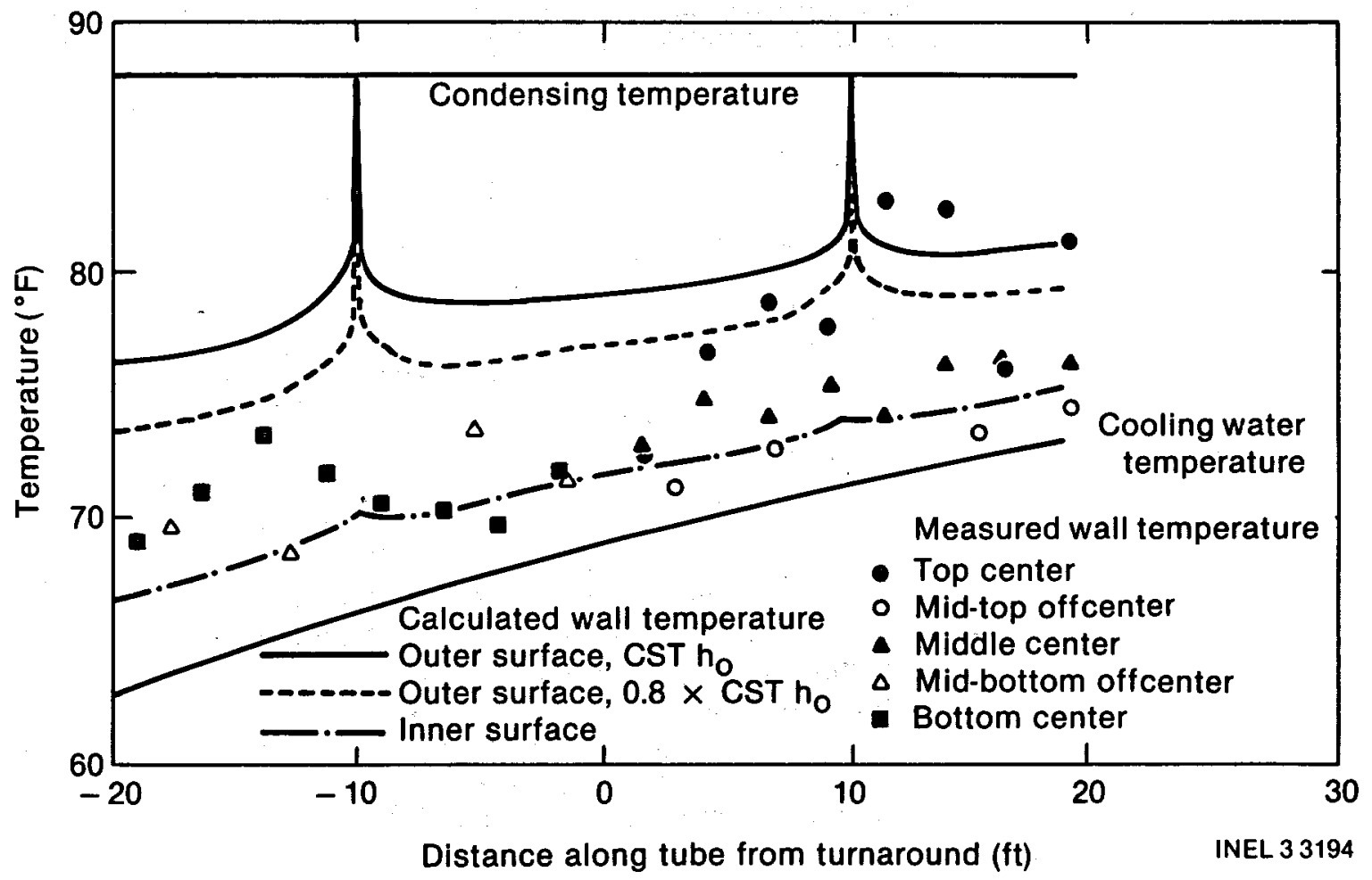

Figure 27. Comparison of measured and calculated condenser tube temperatures-Test 1A.

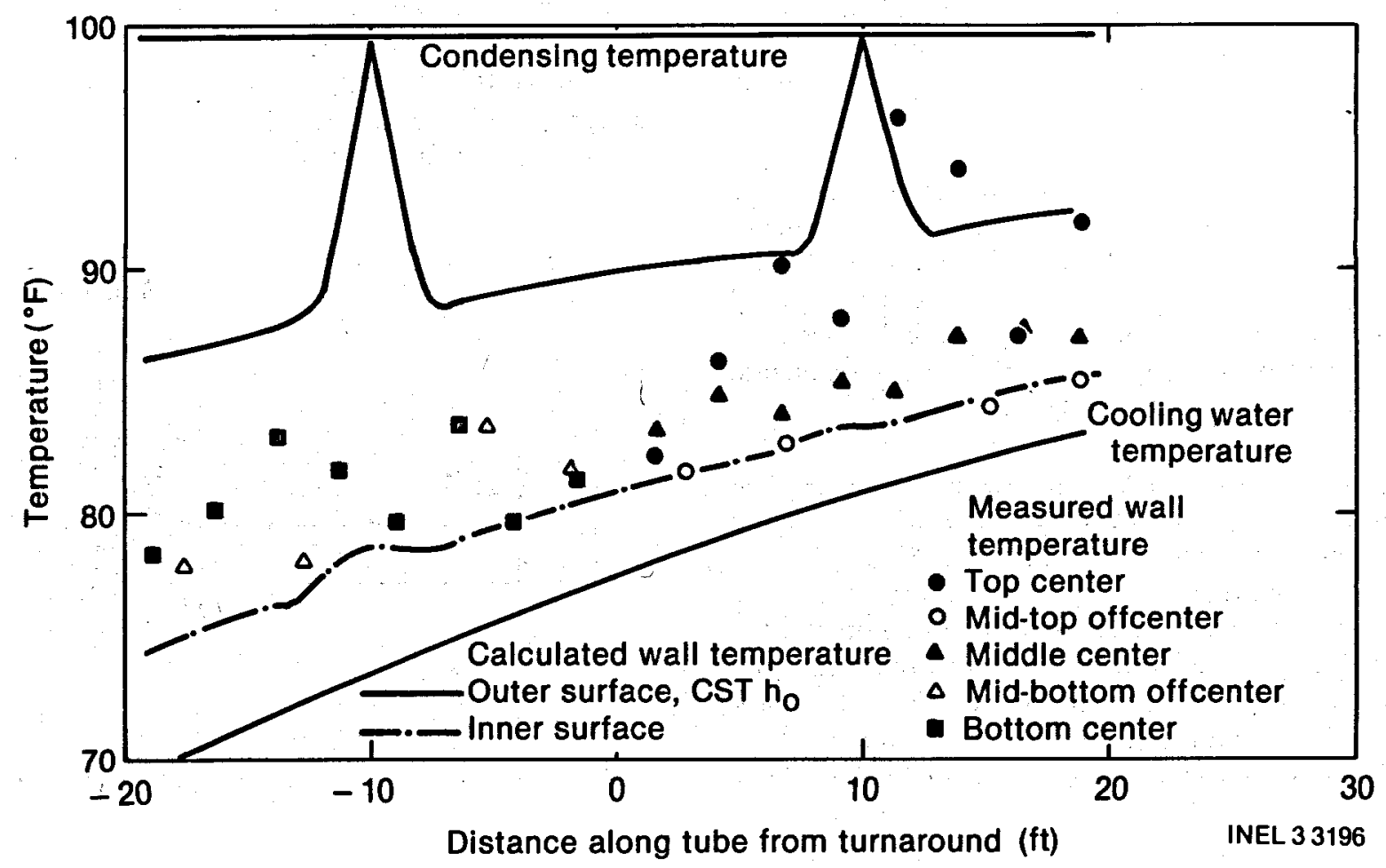

Figure 28. Comparison of measured and calculated condenser tube temperatures-Test 1BTL. 


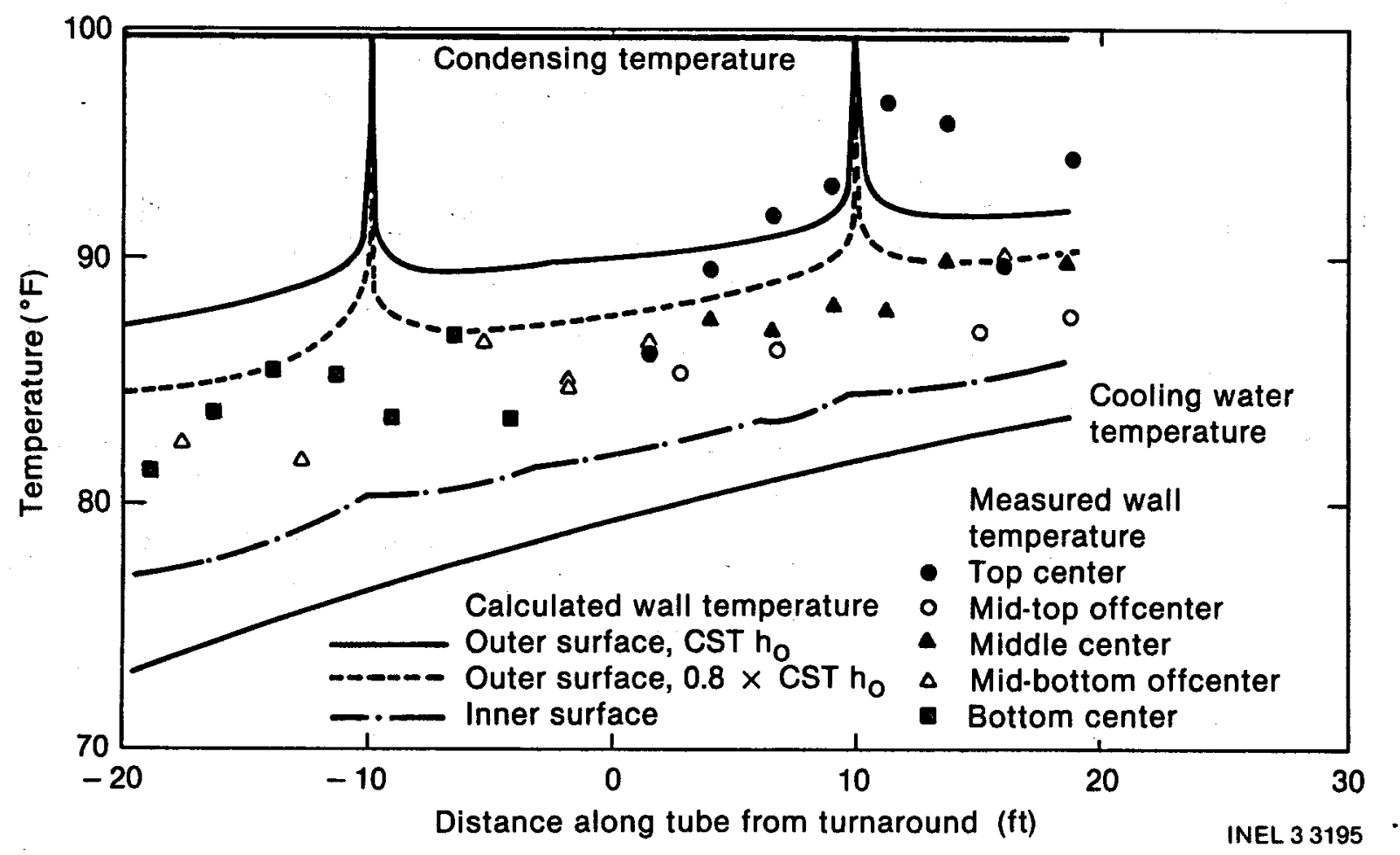

Figure 29. Comparison of measured and calculated condenser tube temperatures-Test 7AR.

would have "insulated" the tube wall from the coolant and allowed the higher film coefficients on the outside surface under the nozzle to pull up the wall temperatures to values nearer the saturation temperature. This latter trend is evident in the data.

Preheaters. The two isobutane preheaters in the system, manufactured by Yuba Heat Transfer Corporation, were both counterflow shell-andtube heat exchangers with the geothermal fluid flowing on the tube side for ease in cleaning. Externally finned tubes and double-segmental baffles were used in both units.

The low-temperature preheater was an F-shell heat exchanger with two shell side passes, resulting in predominately a counterflow. Figure 30 is a schematic representation of the preheater. For simplicity, the transverse baffles have been omitted and only a single tube is shown to represent each tube pass instead of depicting the entire tube bundle. The manufacturer's data showed that the lowpressure preheater is designed for $1,040,000 \mathrm{lb} / \mathrm{h}$ of geothermal fluid entering at $190^{\circ} \mathrm{F}$ and leaving at $125.5^{\circ} \mathrm{F}$, and $934,000 \mathrm{lb} / \mathrm{h}$ of isobutane entering at $66^{\circ} \mathrm{F}$ and leaving at $176^{\circ} \mathrm{F}$. The heat exchanged at these conditions was $67,100,000 \mathrm{Btu} / \mathrm{h}$ with a mean temperature difference of $29.7^{\circ} \mathrm{F}$ and a total heat transfer surface area of $30,030 \mathrm{ft}^{2}$. This resulted in an overall heat transfer coefficient of $75.3 \mathrm{Btu} / \mathrm{h} \mathrm{ft}^{2}{ }^{\circ} \mathrm{F}$. Fouling resistances assumed for design were $0.00053 \mathrm{~h} \mathrm{ft}^{2}{ }^{\circ} \mathrm{F} / \mathrm{Btu}$ (for the shell (isobutane) side and $0.00619 \mathrm{~h} \mathrm{ft}^{2}{ }^{\circ} \mathrm{F} / \mathrm{Btu}$ for the

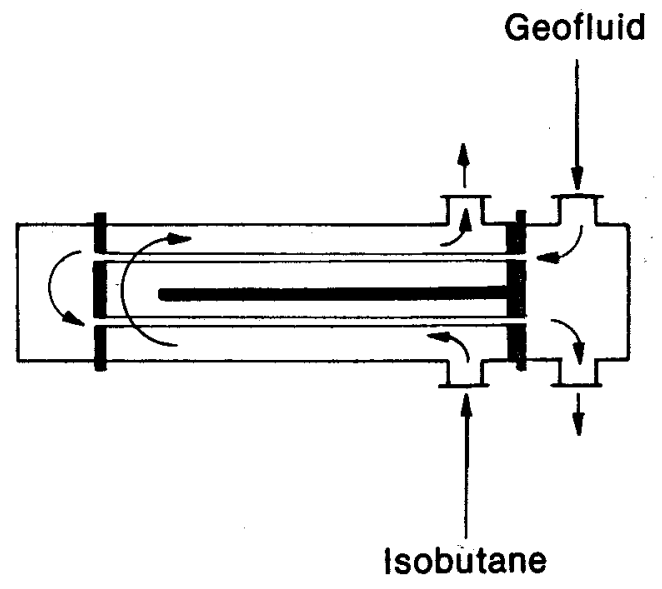

INEL 33221

Figure 30. Low-temperature preheater configuration. 
tube (geothermal fluid) side, both referenced to the tube outside area. Resultant film coefficients were $303 \mathrm{Btu} / \mathrm{h} \mathrm{ft}^{2}{ }^{\circ} \mathrm{F}$ on the shell side and $442 \mathrm{Btu} / \mathrm{h} \mathrm{ft}{ }^{2}$ o $\mathrm{F}$ on the tube side, referenced to the tube outside area. The tubes were the extended surface type with a fin efficiency factor of 0.94 .

The design operating pressures were $421.7 \mathrm{psia}$ on the shell side and 152.2 psia on the tube side. Calculated pressure drops were $4.4 \mathrm{psi}$ on the shell side and $8.8 \mathrm{psi}$ on the tube side.

The high-temperature preheater was an E-shell heat exchanger with one shell side pass and one tube side pass in counterflow. Figure 31 is a schematic representation of this preheater. It is depicted in the same manner as is the low preheater. The manufacturer's data showed that the high-temperature preheater was designed for $1,040,000 \mathrm{lb} / \mathrm{h}$ of geothermal fluid entering at $250^{\circ} \mathrm{F}$ and leaving at $222.5^{\circ} \mathrm{F}$, and $934,000 \mathrm{lb} / \mathrm{h}$ of isobutane entering at $178^{\circ} \mathrm{F}$ and leaving at $238^{\circ} \mathrm{F}$. The heat exchanged at these conditions was $28,000,000 \mathrm{Btu} / \mathrm{h}$ with a mean temperature difference of $24.8^{\circ} \mathrm{F}$ and a total heat transfer surface area of $15,059 \mathrm{ft}^{2}$. This resulted in an overall heat transfer coefficient of $77.1 \mathrm{Btu} / \mathrm{h} \mathrm{ft}{ }^{2}{ }^{\circ} \mathrm{F}$. Fouling resistances assumed for design were $0.00053 \mathrm{~h} \mathrm{ft}^{2}{ }^{\circ} \mathrm{F} / \mathrm{Btu}$ for the shell (isobutane) side and $0.00619 \mathrm{~h} \mathrm{ft}^{2}{ }^{\circ} \mathrm{F} / \mathrm{Btu}$ for the tube (geothermal fluid) side, both referenced to the tube outside area. Resultant film coefficients were $288 \mathrm{Btu} / \mathrm{h} \mathrm{ft}^{2}{ }^{\circ} \mathrm{F}$ on the shell side and $613 \mathrm{Btu} / \mathrm{h} \mathrm{ft}{ }^{2}{ }^{\circ} \mathrm{F}$ on the tube side, referenced to the tube outside area. The tubes were the extended surface type with a fin efficiency factor of 0.94 .

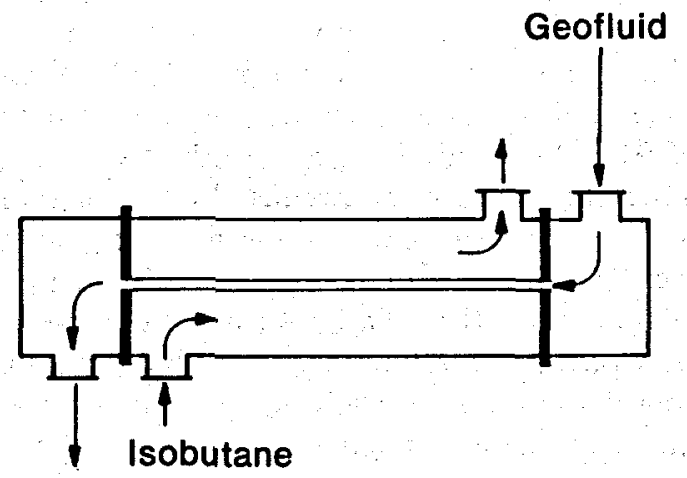

INEL 33220

Figure 31. High-temperature preheater configuration.
The design operating pressures were 417.2 psia on the shell side and 172.2 psia on the tube side. Calculated pressure drops were $3.5 \mathrm{psi}$ on the shell side and $4.8 \mathrm{psi}$ on the tube side.

Baseline Performance-As was done for the condenser, baseline runs were made for the two preheaters for comparison with the manufacturer's design predictions of performance of the as-built units. Both units were analyzed with the ST-4 Mod 5.3 computer code written by HTRI. Inlet and outlet temperatures of both fluids and flow rates were input into the code, together with the geometrical specifications of the preheaters. Properties were obtained from the same sources as previously described for the condenser.

The rated thermal performance of the lowtemperature preheater as predicted by ST -4 was about $11 \%$ higher than that stated by the manufacturer, while ST-4 predicted that the hightemperature preheater would perform about $19 \%$ better than the manufacturer's estimate. This may indicate a conservatism in the manufacturer's overall heat transfer coefficient.

For the low-temperature preheater, the shell side pressure drop predicted by ST-4 was about 47 psia, while the manufacturer estimated only 4.4 psia. This is felt in part to be a problem with the computer code. The baffle arrangement is not a standard one as defined by HTRI, and the code conversion is suspect. Alternate calculations produced shell side pressure drops on the order of 20 psi for this configuration. As will be discussed in a later section, the test data also appears to indicate significantly higher pressure drops than the manufacturer predicted. The tube side pressure drop of 7.8 psi as predicted by ST-4 was close to the manufacturer's estimate of $8.8 \mathrm{psi}$.

The shell side pressure drop in the hightemperature preheated was predicted by ST -4 to be 7.3 psi as compared with the manufacturer's estimate of $3.5 \mathrm{psi}$, and ST-4 predicted $4.4 \mathrm{psi}$ on the tube side versus $4.8 \mathrm{psi}$ from the manufacturer. These predictions compare somewhat better than those for the low-temperature preheater.

In-Service Performance-An attempt was made to run the low-temperature preheater test data on the ST-4 code for comparison with the baseline performance results. Because of the limited maximum performance of the isobutane feed pumps, 
as will be discussed in more detail in the System Performance section, the flow rates were lower than the design values. The test data indicates temperature approaches of the order of $1^{\circ} \mathrm{F}$, confirming that the exchanger is oversized for the majority of the test conditions. Figure 32 shows the measured temperatures in the unit for Test Run 1A. It is clear that because of the low heat duty required, the close temperature approach extends well into the exchanger, perhaps even into the first half. Using the measured temperatures, the calculated leakage across the longitudinal baffle is as much as $11.5 \%$ of the total heat transfer. This is extremely high and is attributed to a combination of the lower-than-design flows and lack of provisions to insulate the horizontal baffle. When attempting to use the ST-4 code to predict effective fouling for this heat exchanger, for the close approach temperatures observed, it was

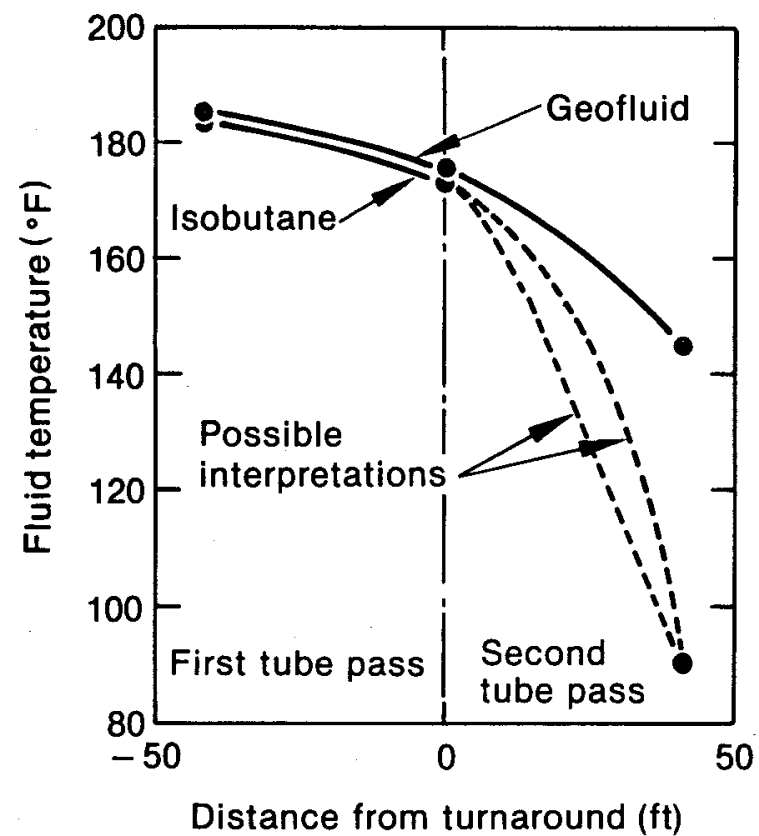

Heat transfer rate $\left(B t u / h \times 10^{-6}\right)$

(calculated from experimental temperature)

\begin{tabular}{|c|c|c|c|}
\hline & $\begin{array}{l}\text { First } \\
\text { tube } \\
\text { pass }\end{array}$ & $\begin{array}{l}\text { Second } \\
\text { tube } \\
\text { pass }\end{array}$ & Total \\
\hline $\begin{array}{l}\text { Geofluid: } \\
\text { Isobutane: }\end{array}$ & $\begin{array}{r}-9.616 \\
4.994\end{array}$ & $\begin{array}{r}-30.997 \\
35.766\end{array}$ & $\begin{array}{r}40.635 \\
40.760 \\
-0144\end{array}$ \\
\hline $\begin{array}{l}\text { Through } \\
\text { baffle: }\end{array}$ & 4.626 & -4.770 & -0.144 \\
\hline
\end{tabular}

Figure 32. Low-pressure preheater measured fluid temperature-Test $1 \mathrm{~A}$. found that physically inadmissible internal temperatures were predicted (a temperature cross). It was concluded that adequate representation was not obtained using the present modeling approach, and that the uncertainties involved preclude the calculation of effective fouling resistances as done for the condenser, but the data is important in pointing out the loss in performance when a heat exchanger is used far from its design point.

Although the computer runs were not usable from a thermal standpoint, they did provide an estimate of the pressure drops predicted by ST-4. For the four cases run, for the low-temperature preheater the shell side pressure drop was calculated by ST -4 to be 27 to $28 \mathrm{psi}$, and the tube side pressure drops about 6 to $7 \mathrm{psi}$, dependent on the flows. As previously discussed, there was a significant disagreement between the ST-4 predictions and those from the manufacturer for the shell side pressure drop with the design conditions. It was postulated that the 47 psi prediction by ST-4 may have been in error because of the unusual internal baffle structure used in the lowpressure preheater-the unit uses horizontal double-segmental baffles with cuts parallel to the longitudinal baffle. This baffle configuration is uncommon and the ST- 4 code must change the cut to vertical in order to run. Additional runs were made with the heat exchangers simulated by two E-shell units with the same flow areas. ST-4 allows horizontal double-segmented baffles with the E-shell. These results still indicated pressure drops which were on the order of 20 psi. The pressure gauges installed were not adequate to resolve this discrepancy because they were not positioned solely across the preheater-other valves were included in the pressure drop. However, using pressure drops of the included components, a preheater pressure drop of about 19 psi was obtained for a shell side flow of $803,000 \mathrm{lb} / \mathrm{h}$ (scaling this pressure drop to the design flow rate of $93,400 \mathrm{lb} / \mathrm{h}$ gives a pressure drop of $25.7 \mathrm{psi}$, much higher than that predicted by the manufacturer). This measured value seems to be closer to the ST -4 results than those predicted by the manufacturer (less than 4.4 psi for the in-service flow rates), suggesting that the as-built unit had a considerably greater shell side pressure drop than the manufacturer stated.

The analysis of the high-temperature preheater proceeded more smoothly than that of the lowtemperature preheater. The unit is an E-shell 
(Figure 30), and thus does not have the longitudinal baffle and associated problems. Because of the low isobutane flows, there is still a close temperature approach; 2 to $3^{\circ} \mathrm{F}$ is indicated by the test data but there is no data to indicate how far into the unit the minimum approach occurs.

The equivalent fouling resistance, $r_{f}$, was calculated by

$$
\mathrm{r}_{\mathrm{f}}=\frac{1}{1.19 \mathrm{U}_{\mathrm{r}}}-\frac{1}{\mathrm{U}_{\mathrm{o}}}
$$

In this equation, 1.19 is the adjustment to match the ST-4 output to manufacturer's performance. The quantities are identical to those defined previously for the condenser.

Figure 25 shows the performance of the highpressure preheater for the same 11 tests as for the condenser. The values, open triangler show a performance about $50 \%$ better than design, indicating that either there is very little fouling or that the as-built unit was oversized to start with. No discernible trend with time is indicated.

Boilers. The two isobutane boilers in the system were both kettle-type reboilers manufactured by Southwestern Engineering Co., and incorporated two tube side passes in each unit. Figure 33 is a schematic representation of each boiler. For simplicity, baffles are not shown and only one tube is depicted for each tube pass rather than the entire tube bundle being shown. The quantities measured are also shown in the figure.
The low-pressure boiler was a kettle-type evaporator designed for $1,040,000 \mathrm{lb} / \mathrm{h}$ of geothermal fluid entering at $222.5^{\circ} \mathrm{F}$ and leaving at $190^{\circ} \mathrm{F}$, and $321,000 \mathrm{lb} / \mathrm{h}$ of isobutane entering at $178^{\circ} \mathrm{F}$ and boiling at $180^{\circ} \mathrm{F}$. The heat exchanged at these conditions was $33,800,000 \mathrm{Btu} / \mathrm{h}$ with a mean temperature difference of $22.46^{\circ} \mathrm{F}$ and a total heat transfer surface area of $5938 \mathrm{ft}^{2}$. This resulted in an overall heat transfer coefficient of $254 \mathrm{Btu} / \mathrm{h} \mathrm{ft}^{2}{ }^{\circ} \mathrm{F}$.

Fouling resistances assumed for design were $0.0005 \mathrm{~h} \mathrm{ft}^{2}{ }^{\circ} \mathrm{F} / \mathrm{Btu}$ for the shell (isobutane) side and $0.00181 \mathrm{~h} \mathrm{ft}^{2}{ }^{\circ} \mathrm{F} / \mathrm{Btu}$ for the tube (geothermal fluid) side, both reference to the tube outside area. Resultant film coefficients were $1546 \mathrm{Btu} / \mathrm{h} \mathrm{ft}^{2}{ }^{\circ} \mathrm{F}$ on the tube side and $1134 \mathrm{Btu} / \mathrm{h} \mathrm{ft}{ }^{2} \mathrm{~F}$ on the shell side, both referenced to the tube outside area.

The design operating pressures were 191.5 psig on the shell side and 150 psig on the tube side. Calculated pressure drops were 0.5 psi on the shell side and $7.0 \mathrm{psi}$ on the tube side.

The high-pressure boiler was a kettle-type evaporator designed for $1,040,000 \mathrm{lb} / \mathrm{h}$ of geothermal fluid entering at $290^{\circ} \mathrm{F}$ and leaving at $250^{\circ} \mathrm{F}$, and $613,000 \mathrm{lb} / \mathrm{h}$ of isobutane entering at $238^{\circ} \mathrm{F}$ and boiling at $240^{\circ} \mathrm{F}$. The heat exchanged at these conditions was $42,800,000 \mathrm{Btu} / \mathrm{h}$ with a mean temperature difference of $24.85^{\circ} \mathrm{F}$ and a total heat transfer surface of $5938 \mathrm{ft}^{2}$. This resulted in an overall heat transfer coefficient of $290 \mathrm{Btu} / \mathrm{h} \mathrm{ft}^{2}{ }^{\circ} \mathrm{F}$. Fouling resistances assumed for design were $0.0005 \mathrm{~h} \mathrm{ft}^{2}{ }^{\circ} \mathrm{F} / \mathrm{Btu}$ for the shell (isobutane) side and $0.00181 \mathrm{~h} \mathrm{ft}^{2}{ }^{\circ} \mathrm{F} / \mathrm{Btu}$ for the

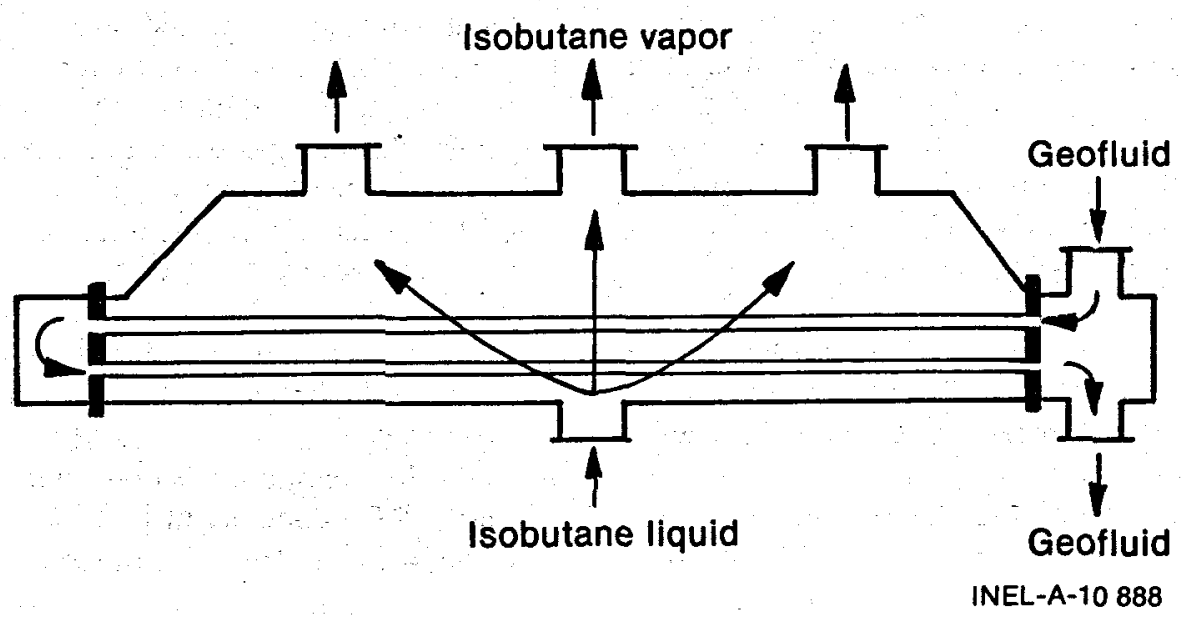

Figure 33. High- and low-pressure boiler configurations. 
tube (geothermal fluid) side, both referenced to the tube outside area. Resultant film coefficients were $1839 \mathrm{Btu} / \mathrm{h} \mathrm{ft}^{2}{ }^{\circ} \mathrm{F}$ on the tube side and $2392 \mathrm{~h} \mathrm{ft}^{2}{ }^{\circ} \mathrm{F} / \mathrm{Btu}$ on the shell side, both referenced to tube outside area.

The design operating pressures were 170 psig on the shell side and $370 \mathrm{psig}$ on the tube side. Calculated pressure drops were $0.5 \mathrm{psi}$ on the shell side and $7.0 \mathrm{psi}$ on the tube side.

Baseline Performance-Baseline runs were made for both boilers for comparison with manufacturer's design performance predictions of the as-built units. Both boilers were analyzed with the RKH-1 Mod 6.00 kettle boiler computer code written by HTRI. The inputs to the RKH-1 code include the inlet and outlet temperatures of both fluids and the boiler pressure. The boiler geometry was obtained from the manufacturer's specifications, while the fluid properties were obtained from the same sources as for the condenser.

Instead of rating heat duties, the RKH-1 code calculates the vapor generation rate and heating fluid flow rate, together with a resulting heat duty.

For the baseline case of the low-pressure boiler, comparison of the RKH-1 results with the manufacturer's specifications showed excellent agreement. All flows and heat transfer parameters were essentially identical to those specified by the manufacturer; variations were well under $1 \%$. The tube side pressure drop predicted by RKH-1 was about $2 \%$ higher than the manufacturer's, and no shell side drop is specified. This agreement was by far the closest of any of the exchangers.

The agreement of the high-pressure boiler calculations was also good. The vapor-generation rate predicted by RKH-1 was about $3 \%$ lower than the manufacturer's, and the tube side flow as about $3 \%$ high. The heat duty was about $2 \%$ lower than the manufacturer's. The calculated tube side pressure drop was about $5 \%$ higher than the manufacturer's specified value.

In-Service Performance-The boilers were evaluated in a somewhat different manner than the other heat exchangers. Computer runs were made with four different fouling resistances and interpolated to determine the fouling resistance that would produce the measured heat duties from four tests. This was done for both the isobutane side and geofluid side heat duties.
The solid triangles in Figure 25 show the results of the study of the low-pressure boiler for four tests spanning the entire test period. Results are presented only for the geofluid heat duty as it is felt to be the most accurate. It is seen that all four tests investigated indicate essentially the same performance and that no significant trends with time are indicated. The levels indicate that the lowpressure boiler performs about $18 \%$ better than design.

The open circles in Figure 25 show similar results for the high-pressure boiler. Fair agreement is seen, with the effective performance being about $15 \%$ worse than design.

The reader is reminded that this change, or difference in performance from design, may be due to fouling which is independent of time, or it may indicate that the as-built performance was somewhat different than the manufacturer estimated.

Summary of Results for the Heat Exchangers. The heat exchanger performance study presented in this section showed that the performance of each unit was somewhat different than that specified by the respective manufacturer, but it was not possible to determine whether it was due to the as-built performance or due to heat exchanger fouling. The monitored difference in performance from design showed no appreciable change with time over the relatively short test period.

The condenser demonstrated a product of heattransfer area and overall heat-transfer coefficient about $25 \%$ lower than design. Tube wall temperatures measured in the condenser seem to indicate that the fouling incurred was on the inside of the tubes as expected, an indication in general agreement with the observed tube fouling. In comparison with CST-1 predictions of outer surface temperatures, the measured temperatures are in general lower, indicating that the actual shell side film coefficients are lower than those predicted by CST-1. This may be due to the CST-1 correlations used or possibly degradation of heat transfer due to noncondensable gas build-up. More evaluation using the computer code would be required to estimate the impact of these findings.

The low-temperature preheater could not be run on the ST-4 code because of incomplete modeling of heat transfer through the longitudinal baffle in the F-shell unit at the given operating conditions. Temperatures measured at the turnaround plenum 
indicate that over half the unit is ineffective due to temperature approaches of less than $3^{\circ} \mathrm{F}$. This was due to the low isobutane flow rates in the tests resulting in part from the measured shell side pressure drop being considerably higher than that predicted by the manufacturer. It appears that the low-temperature preheater was overdesigned for the service in which it was used. No operational problems resulted from this overdesign. The temperature of the isobutane was brought to the temperature of the geofluid entering the exchanger. Because the geofluid had passed through all of the other exchangers, this temperature was acceptable from an operational point of view.

The high-temperature preheater showed performance about $50 \%$ better than the manufacturer's estimates. It is not possible to determine whether this deviation is due to overdesign or lower-than-expected fouling.

The high- and low-pressure boilers showed measured performance about $15 \%$ lower and $18 \%$ higher than design, respectively. This is due to the as-built performance and/or fouling being different than design values.

The HTRI computer codes appear to have predicted the actual performance of the units fairly well. The condenser code, CST- 1 appears to have some questionable results. It is not possible to determine whether the problem was in the computer code or in the experiment itself. More time would be required to resolve this question.

The performance of all heat exchangers with the exception of the high-temperature preheater was near design. These tests were carried out early in the life of the exchangers. The tests did not extend over a long enough time for fouling history to be determined. Problems could results if future units are built whose early operation is near design and the fouling increases a large amount during operation.

\section{System Performance}

Introduction. The following section presents the detailed state point data for a typical test. The thermodynamic properties for state points throughout the system are tabulated and mass and energy balances are shown. The results of an availability analysis, indicating the relative irreversibil- ities for each major component, are given. The series of tests which were run are reviewed and correlated to provide an indication of the sensitivity of generated power to some of the system operation parameters such as geofluid-inlet temperature and flow rate and cooling water inlet temperature and flow rate.

\section{Baseline System.}

State Point Data. Experimental data taken during the test were used to calculate thermodynamic properties at state points throughout the system for each test. These calculations include some changes to the original "raw data" from the data acquisition system. Changes were made to pressure readings based on no-flow test conditions, elimination of data from transducers which were determined to have failed, and an estimation of moisture carried from boilers. A summary of the computer listing of the reduced state point data of Test $1 \mathrm{~A}$ is presented in Table 7, together with the mass flow rates and energy balances for the boilers, heat exchangers, and condenser. These are the best estimates of the cycle state point data for the test which was nearest the design point. The state points correspond to points in the system as indicated in Figure 9. Test 1A is presented here and in the following availability analysis because it corresponded to the base design operating conditions. The test that produced the maximum power was not used because the liquid level in both the high-and low-pressure boiler was so high that it was not possible to estimate the amount of moisture that was being carried from the boilers.

Generally, mass and energy balances were good. The greatest difference in the calculated parameters was between the calculated heat transfer rate from the geofluid compared with that into the isobutane working fluid in the high-pressure boiler. The calculated heat from the geofluid was $8.5 \%$ lower than that calculated to be transferred to the isobutane. For the 17 tests which were examined, the calculated heat transfer rate from the geofluid was consistently lower than the calculated rate into the isobutane, averaging $10.4 \%$ lower for the turbine powered cases and 9.9\% lower for the thermal loop (without turbine) cases. This difference is attributed to some error in the sensors or the possibility that there was some isobutane leakage through return lines to the condensate storage tank. 
Test: 1A Date: 10/May/82 Time: 03:51:00

Ambient: Press $/$ psia $=12.3$ Dry bulb $/{ }^{\circ} \mathrm{F}=36.0$ Wet bulb $/{ }^{\circ} \mathrm{F}=35.0$

Generator/kW: 4010.0

\begin{tabular}{|c|c|c|c|c|c|c|c|}
\hline State Point & $\begin{array}{l}\text { Pressure } \\
\text { (psia) }\end{array}$ & $\begin{array}{c}\text { Temperature } \\
\left({ }^{\circ} \mathrm{F}\right)\end{array}$ & $\begin{array}{c}\text { Specific Volume } \\
\left(\mathrm{ft}^{3} / \mathrm{lbm}\right)\end{array}$ & $\begin{array}{l}\text { Enthalpy } \\
\text { (Btu/lbm) }\end{array}$ & $\begin{array}{c}\text { Entropy } \\
\left(\mathrm{Btu} / \mathrm{lbm} /{ }^{\circ} \mathrm{F}\right)\end{array}$ & Quality & $\begin{array}{c}\text { Flow } \\
(\mathrm{lbm} / \mathrm{h})\end{array}$ \\
\hline \multicolumn{8}{|l|}{ Geofluid } \\
\hline 1 & $0.0^{\mathrm{a}}$ & 0.0 & 0.00000 & 0.00 & 0.0000 & - & 0 \\
\hline 2 & 75.1 & 280.5 & 0.01727 & 249.74 & 0.4105 & - & 1029534 \\
\hline 3 & 0.0 & 0.0 & 0.00000 & 0.00 & 0.0000 & - & 0 \\
\hline 4 & 174.9 & 279.0 & 0.01725 & 248.40 & 0.4082 & - & 0 \\
\hline 5 & 173.0 & 247.3 & 0.01697 & 216.16 & 0.3636 & - & 0 \\
\hline 6 & 163.9 & 214.8 & 0.01673 & 183.32 & 0.3161 & - & 0 \\
\hline 7 & 157.8 & 184.8 & 0.01653 & 153.17 & 0.2704 & - & 0 \\
\hline 8 & 151.7 & 145.6 & 0.01631 & 113.92 & 0.2075 & - & 990228 \\
\hline 9 & 0.0 & 0.0 & 0.00000 & 0.00 & 0.0000 & - & 0 \\
\hline 10 & 0.0 & 0.0 & 0.00000 & $\quad 0.00$ & 0.0000 & - & 0 \\
\hline 11 & 151.7 & 145.6 & 0.01631 & 113.92 & 0.2075 & - & -1819 \\
\hline
\end{tabular}

Isobutane

\begin{tabular}{|c|c|c|c|c|c|c|c|}
\hline 12 & 61.1 & 88.1 & 0.02933 & -792.92 & 0.9080 & SATL & 0 \\
\hline 13A & 435.0 & 91.4 & 0.02910 & -790.40 & 0.9089 & 0.000 & 438809 \\
\hline $13 B$ & 432.7 & 92.1 & 0.02913 & -790.00 & 0.9097 & 0.000 & 407072 \\
\hline $13 \mathrm{C}$ & 433.8 & 91.9 & 0.02912 & -790.11 & 0.9094 & 0.000 & 846781 \\
\hline 14 & 427.5 & 91.0 & 0.02909 & -790.64 & 0.9085 & 0.000 & 684103 \\
\hline 15 & 427.5 & 91.0 & 0.02909 & -790.64 & 0.9085 & 0.000 & 0 \\
\hline 16 & 412.8 & 184.0 & 0.03405 & -731.46 & 1.0077 & 0.000 & 0 \\
\hline 17 & 412.8 & 167.7 & 0.03282 & -742.83 & 0.9898 & 0.000 & 0 \\
\hline 18 & 0.0 & 0.0 & 0.00000 & 0.00 & 0.0000 & 0.000 & 0 \\
\hline 19 & 412.8 & 167.7 & 0.03282 & -742.83 & 0.9898 & 0.000 & 519267 \\
\hline 20 & 412.8 & 167.7 & 0.03282 & -742.83 & 0.9898 & 0.000 & 0 \\
\hline 21 & 406.9 & 244.8 & 0.04524 & -678.12 & 1.0867 & 0.000 & 0 \\
\hline 22 & 406.9 & 243.1 & 0.04443 & -680.28 & 1.0836 & 0.000 & 537221 \\
\hline 23 & 395.4 & 242.6 & 0.04465 & -680.27 & 1.0837 & SATL & 0 \\
\hline 24 & 373.0 & 236.5 & 0.20401 & -612.36 & 1.1816 & SATV & 0 \\
\hline 24 & 373.0 & 236.5 & 0.19966 & -614.36 & 1.1787 & 0.973 & 0 \\
\hline 25 & 372.8 & 236.4 & 0.19983 & -614.36 & 1.1787 & 0.973 & 537221 \\
\hline $25 \mathrm{~A}$ & 372.8 & 236.4 & 0.19983 & -614.36 & 1.1787 & 0.973 & 537221 \\
\hline 26 & 322.1 & 222.1 & 0.25120 & -614.36 & 1.1818 & 1.000 & 0 \\
\hline 27 & 0.0 & 0.0 & 0.00000 & 0.00 & 0.0000 & 0.000 & 0 \\
\hline 28 & 0.0 & 0.0 & 0.00000 & 0.00 & 0.0000 & 0.000 & 0 \\
\hline 29 & 412.8 & 167.7 & 0.03282 & -742.83 & 0.9898 & 0.000 & 336043 \\
\hline 30 & 204.8 & 165.6 & 0.03325 & -743.80 & 0.9903 & 0.000 & 0 \\
\hline 31 & 201.7 & 177.8 & 0.43750 & -625.52 & 1.1760 & SATV & 0 \\
\hline 31 & 201.7 & 177.8 & 0.33065 & -654.56 & 1.1305 & 0.735 & 0 \\
\hline 32 & 201.7 & 177.8 & 0.33065 & -654.56 & 1.1305 & 0.735 & 336043 \\
\hline $32 \mathrm{~A}$ & 201.7 & 177.8 & 0.33065 & -654.56 & 1.1305 & 0.735 & 336043 \\
\hline 33 & 172.9 & 164.5 & 0.41130 & -654.56 & 1.1336 & 0.781 & 0 \\
\hline 34 & 0.0 & 0.0 & 0.00000 & 0.00 & 0.0000 & 0.000 & 0 \\
\hline 35 & 0.0 & 0.0 & 0.00000 & 0.00 & 0.0000 & 0.000 & 0 \\
\hline 36 & 60.2 & 102.2 & 1.55599 & -647.00 & 1.1747 & 1.000 & 0 \\
\hline 37 & 61.1 & 88.1 & 0.02933 & -792.92 & 0.9080 & SATL & 0 \\
\hline 38 & 0.0 & 0.0 & 0.00000 & 0.00 & 0.0000 & 0.000 & 0 \\
\hline
\end{tabular}


Table 7. (continued)

Test: 1A Date: 10/May/82 rime: 03:51:00

Ambient: Press $/ \mathrm{psia}=12.3$ Dry bulb $/{ }^{\circ} \mathrm{F}=36.0$ Wet bulb $/{ }^{\circ} \mathrm{F}=35.0$

Generator/kW: 4010.0

\begin{tabular}{|c|c|c|c|c|c|c|c|}
\hline State Point & $\begin{array}{c}\text { Pressure } \\
\text { (psia) } \\
\end{array}$ & $\begin{array}{c}\text { Temperature } \\
(\mathbf{F}) \\
\end{array}$ & $\begin{array}{c}\text { Specilic Volume } \\
\left(\mathrm{t}^{3} / \mathrm{bm}\right)\end{array}$ & $\begin{array}{c}\text { Enthalpy } \\
\text { (Btu/lbm) }\end{array}$ & $\begin{array}{c}\text { Entropy } \\
(\text { Btu//bn//'F) }\end{array}$ & Quality & $\begin{array}{l}\text { Flow: } \\
(\mathrm{lbm} / \mathrm{h})\end{array}$ \\
\hline Cooling Water & & . & & & & & \\
\hline 39 & 0.0 & 0.0 & 0.00000 & 0.00 & 0.0000 & - & 0 \\
\hline 40 & 53.7 & 58.1 & 0.01603 & 26.31 & 0.0517 & - & 5974276 \\
\hline 41 & 36.6 & 78.3 & 0.01607 & 46.44 & 0.0900 & - & 0 \\
\hline 42 & 36.6 & 78.3 & 0.01607 & 46.44 & 0.0900 & - & 6004997 \\
\hline 43 & 36.6 & 78.3 & 0.01607 & 46.44 & 0.0900 & - & 15429 \\
\hline 44 & 36.6 & 78.3 & 0.01607 & 46.44 & 0.0900 & - & 116289 \\
\hline
\end{tabular}

a. 0.0 in the table indicates that no experimental data existed at that state point.

Mass Balances

Geofluid

MDOT $(2+11)(\mathrm{lbm} / \mathrm{h})=1027715$

MDOT (8) $(\mathrm{lbm} / \mathrm{h})=990228$

Average $(\mathrm{lbm} / \mathrm{h})=1008971$

Difference $(\%)=-3.72$

Cooling water

MDOT $(42+43-44)(\mathrm{lbm} / \mathrm{h})=5904136$

MDOT $(40)(\mathrm{lbm} / \mathrm{h})=5974276$

Average $(\mathrm{lbm} / \mathrm{h})=5939206$

Difference $(\%)=1.18$

Low preheater bypass flow fraction

Alpha $=0.192$

High preheater bypass flow fraction

Beta $=0.033$

Preliminary energy balances

Overall balance

Energy from geofluid $(\mathrm{Btu} / \mathrm{h})=135686011$

Energy from isobutane Pump A (Btu/h) $=1116677$

Energy from isobutane Pump B $(B t u / h)=1043178$

Total energy into isobutane $(B t u / h)=137845866$

Energy to cooling water $(\mathrm{Btu} / \mathrm{h})=119558840$

Energy to turbine $(B t u / h)=14895632$

Total energy out of isobutane $(B t u / h)=134454473$

Difference in total energy $(\%)=2.49$
Individual balances

Low preheater

Geofluid $(\mathrm{Btu} / \mathrm{h})=39600884$

Isobutane $(B t u / h)=40488492$

Average $(\mathrm{Btu} / \mathrm{h})=40044688$

Difference $(\%)=-2.22$

Low boiler

Geofluid (Btu/h) $=30426859$

Isobutane $(\mathrm{Btu} / \mathrm{h})=29662618$

Average $(B t u / h)=30044738$

Difference $(\%)=2.54$

High preheater

Geofluid $($ Btu/h) $=33131712$

Isobutane $(\mathrm{Btu} / \mathrm{h})=33602034$

Average $(\mathrm{Btu} / \mathrm{h})=33366873$

Difference $(\%)=-1.41$

High boiler

Geofluid $(B t u / h)=32526556$

Isobutane $(B t u / h)=35411963$

Average $(\mathrm{Btu} / \mathrm{h})=33969260$

Difference $(\%)=\mathbf{- 8 . 4 9}$

Condenser

Cooling water $(B t u / h)=119558840$

Isobutane $(\mathrm{Btu} / \mathrm{h})=123564178$

Average $(B t u / h)=121561509$

Difference $(\%)=-3.29$. 
Availability-Irreversibility Analysis. Determining the actual overall performance of the plant is the prime purpose of this section of this report. The ideas associated with an availability-irreversibility analysis allow the performance of the system to be considered in the perspective of the thermody- namic ideal and assess the losses in thermodynamic performance attributable to the individual components.

Figure 34 presents the results of such a study on the baseline case (Test $1 \mathrm{~A}$ ). If the plant itself is

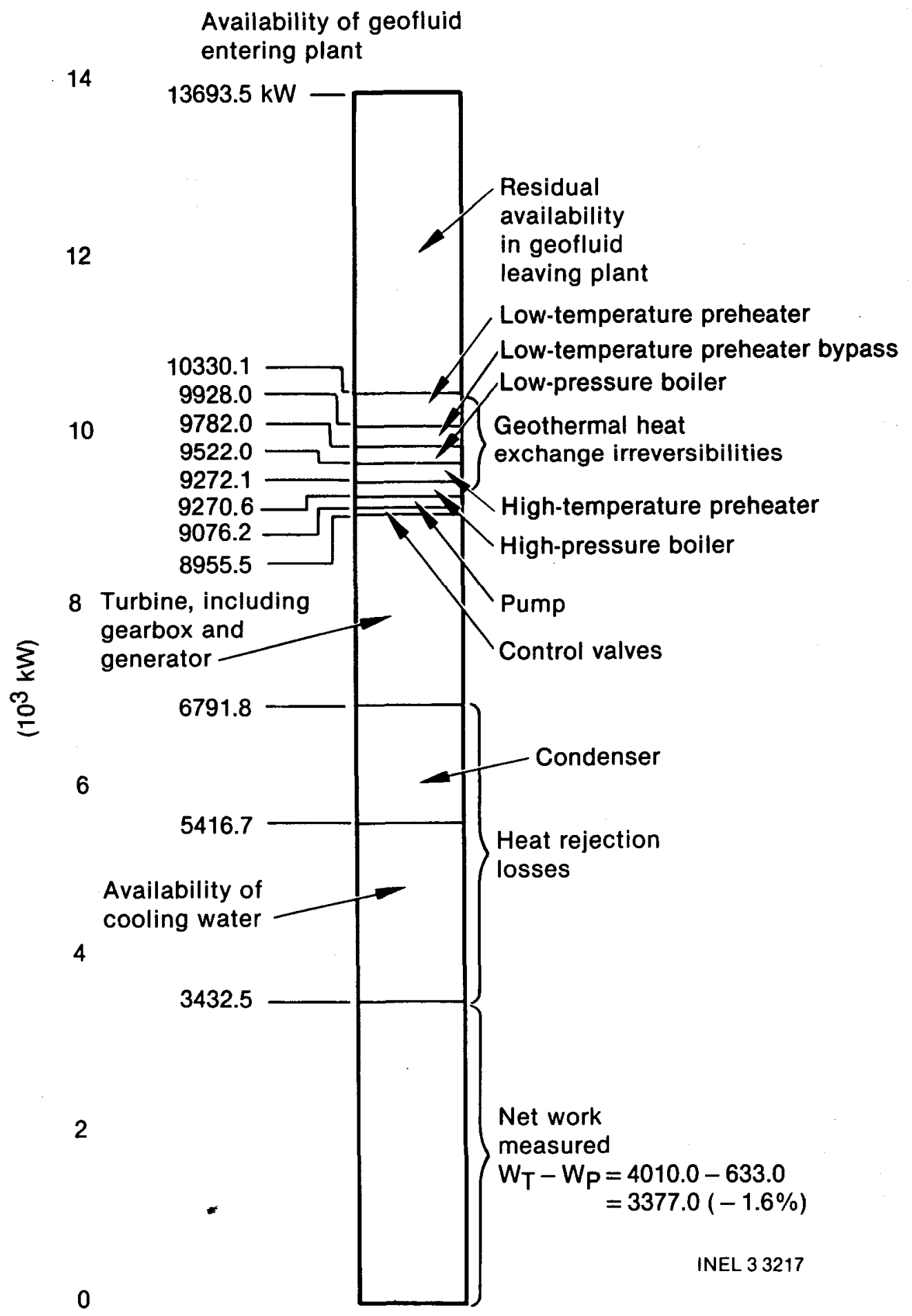

Figure 34. Loss of availability through system, calculated for Test 1A. 
considered to be this system of interest, there are a number of things external to the system that are affected by it. The geofluid leaving the plant has a lower thermodynamic availability than that entering the plant, creating a decrease in availability of things external to the plant. The cooling water increases in availability as it flows through the plant condenser. These processes create increases in availability external to the plant. [The remainder of the cooling water loop (pumps and cooling tower) were not included in the system because the state points in the cooling tower were not known with sufficient accuracy.] The algebraic sum of all of the changes in availability external to the system is equal to the sum of the irreversibilities of the components within the system. The irreversibilities of each of the components within the system were calculated separately along with the availability of each flow into or out of the system. The dead (atmospheric) states were taken as the wet bulb temperature, $35^{\circ} \mathrm{F}$ and atmospheric pressure, 12.5 psia.

Beginning with the availability of the geofluid entering the plant relative to the dead state, $13694 \mathrm{~kW}$, (Figure 34) the residual availability of the geofluid leaving the plant $(3364 \mathrm{~kW})$ is subtracted to give the change in availability of the geofluid as it flows through the plant. The irreversibilities of the individual geothermal heat exchangers and the mixing processes associated with the preheater bypass streams $(1059 \mathrm{~kW})$ are then subtracted. The irreversibilities associated with the isobutane pumps, turbine-generator and control valves $(2479 \mathrm{~kW})$ are subtracted. The losses associated with heat rejection: the condenser irreversibility and the increase in availability of the cooling water ( $3359 \mathrm{~kW})$ are subtracted. (If the cooling water loop had been included within the system, the cooling water pump irreversibility, the cooling tower irreversibility, and the change in availability of the makeup water and atmospheric air could have been quantified. With this analysis, they must be lumped together because there was no good data defining the condition of the air leaving the cooling tower.) The net power from the availability analysis (3433 kW) agrees well with the turbine power less the isobutane pump parasitic $(4210-633=3377 \mathrm{~kW})$, thus lending credibility to the availability loss distribution presented in Figure 34.

The following additional power requirements (in $\mathrm{kW}$ ) were supplied to the plant during operation in this case:
- Production well pumps $=821$

- Geofluid boost pumps $=115$

- $\quad$ Injection well pumps $=\mathbf{4 4 8}$

- Cooling water fans $=134$

- $\quad$ Cooling water pumps $=388$.

If these power requirements were subtracted from the net plant power of $3433 \mathrm{~kW}$, (Figure 34) from the availability analysis, the net power produced during Test $1 \mathrm{~A}$ would have been $1516 \mathrm{~kW}$. This number may be abnormally low because the power expended in the geothermal supply and injection system was relatively high. The supply and injection system was not designed for the purpose of supplying the plant only and expends more power than a properly designed and matched system. Therefore, the more typical value to consider is that for the plant without the supply and injection system. For Test $1 \mathrm{~A}$ the plant produced $2900 \mathrm{~kW}$ exclusive of any supply and injection system parasitic power losses.

Sensitivity Studies. The test program for the Raft River facility was designed to provide operational information through a broad range of conditions. The series of tests (see Table 4) was planned to provide information about the sensitivity of steady-state operation to various key operational parameters. The tests were specified to vary one operating parameter while holding other plant conditions constant. The following plots indicate the sensitivity of the power to each of several test variables. Calculated turbine power was used for the sensitivity studies since for approximately half of the tests the turbine was not operational. The power was calculated from the isentropic drop in enthalpy from the boiler to the condenser pressure and then adjusted by the manufacturer's data for the turbine efficiency and gearbox and generator losses. This calculated power was in good agreement, with turbine power averaging $6.8 \%$ higher than the indicated generator output during the turbine powered tests.

As shown in Table 4, there were variations in the tests from the specified conditions. The coolant inlet temperature varied significantly and an adjustment was made to the calculated generator power to account for this off-nominal test condition. The change consisted of adjusting 
the turbine outlet pressure to account for the difference between the coolant inlet temperature specified for the test and the actual coolant temperature during the test. To make this adjustment, the condensing temperature was assumed to change by the same amount as the coolant temperature.

The sensitivity of the system power to geofluid inlet temperature is shown in Figure 35. This data is taken from Tests $1 \mathrm{~A}, 7 \mathrm{AR}, 7 \mathrm{BR}$, and $7 \mathrm{C}$ with the adjustments for coolant inlet temperature as stated. Also plotted on this graph are the results of the system simulator prior to running the tests described in Reference 6. Both the actual flow rate of the tests and the design flow rate curves are plotted. The experimental points have approximately $6 \%$ lower power than the predicted power at the actual flow and approximately $8 \%$ lower power than the design flow rate prediction. The change of generator output with respect to geofluid inlet temperature is $41 \mathrm{~kW} /{ }^{\circ} \mathrm{F}$ compared to $45 \mathrm{~kW} /{ }^{\circ} \mathrm{F}$ for the pretest predictions.

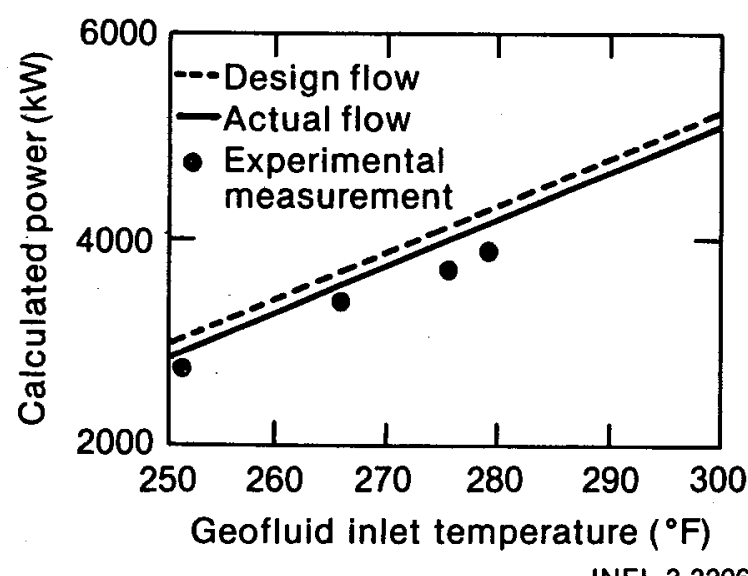

Figure 35. Sensitivity of turbine output to changes in geofluid temperature.

The sensitivity of the system power to geofluid mass flow rate is shown in Figure 36. This data is a comparison of Tests $1 \mathrm{~A}, 5 \mathrm{~B}$, and $5 \mathrm{C}$ for the $280^{\circ} \mathrm{F}$ inlet temperature and Test 6 and $7 \mathrm{~B}$ for the $265^{\circ} \mathrm{F}$ inlet temperature. The results of the prediction from the system simulation (see Reference 6) are also shown on the graph. For the $280^{\circ} \mathrm{F}$ inlet brine temperature cases, the expected points average $11 \%$ below the prediction, and for the $265^{\circ} \mathrm{F}$ inlet temperature, the experimental data is an average of $6 \%$ below prediction. Note that the

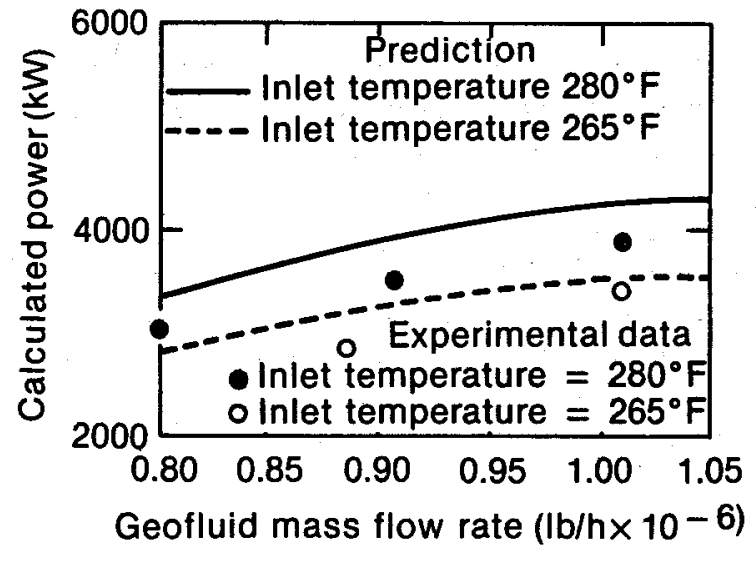

INEL 33204

Figure 36. Sensitivity of generator output to geofluid flow rate.

relation between geofluid flow rate and power output is quite nonlinear compared with the relation of geofluid temperature and power.

The sensitivity of generator power to cooling water flow rate is not plotted. Only Tests $1 \mathrm{~A}$ and $1 B$ were run in this series and they were all more than $20 \%$ below the design value. For these tests the slope of the generator output relative to cooling water flow rate was $-2.5 \mathrm{kWh} / \mathrm{lb}$.

The sensitivity of the system power to cooling water inlet temperature is shown in Figure 37. This compares the results of Tests 1A, 3ATL, 3BTL, and $3 \mathrm{C}$ for the $100 \%$ of design geofluid mass flow rate and Tests 5C, 4BTL, 4ATL, and $4 C T L$ for the $80 \%$ of design geofluid mass flow rate.

System Transients. Before plant operation, an analytical effort was undertaken to predict the plant performance in both steady-state and transient operation. These studies are summarized in References 6 and 7. The results of the studies showed no problems with normal operation. The only predicted problem areas were upsets such as loss of cooling water and control valve failures. No problems were encountered during normal plant operation, however, a turbine trip did upset the system. (This is discussed in greater depth in the Plant Operation section.)

An apparent disagreement between predicted (Reference 7) and actual behavior following a turbine trip was noted. The discrepancy was caused by the failure to consider an isobutane pump trip 


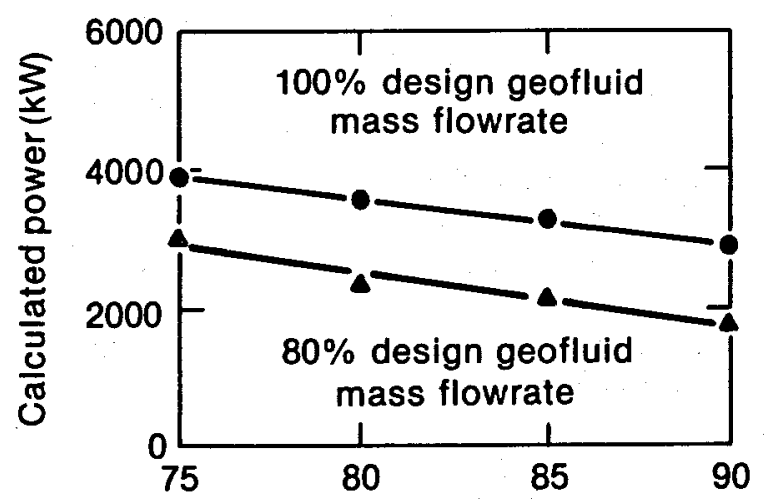

Cooling water inlet temperature $\left({ }^{\circ} \mathrm{F}\right)$

INEL 33203

Figure 37. Sensitivity of generator output to cooling water inlet temperature.

on low flow in the original transient analysis. The actual sequence of events following a turbine trip were:

1. The turbine throttle valves (stop valves) shut almost instantaneously creating a condition of zero vapor flow from the boilers.

2. The liquid flow into the boilers continued, causing the liquid level in the boilers to rise. This caused the boiler feed valve to close in response to the high liquid level. The simulation indicated that both boiler feed valves had closed $14 \mathrm{~s}$ into the trip.

3. At this point there was no flow required by the system, and the isobutane feed pumps tripped out on low flow. The pressure in the boilers now started to rise because the boilers were then isolated but heat was being transferred to them.

4. The valves in the turbine bypass line were activated by the boiler pressure, and vapor began to flow from the boilers.

5. The level in the boiler started to drop and . the boiler feed valves opened to admit liquid flow. If the feed pumps had not tripped out, the supply of liquid to the boiler would have resumed as predicted in the analysis (Reference 7). The simulation indicates that this would have happened at $30 \mathrm{~s}$ into the trip (16 s of zero flow).
There would have been a number of ways to speed up plant recovery following a turbine trip. If a delay had been put on the low-flow trip to sustain the pump through the $16 \mathrm{~s}$ period of no flow, the system would have recovered to the thermal loop much as was indicated in the simulator (complete recovery of boiler flow the level took approximately 400 s). Another, but less efficient, method of alleviating this problem would have been to bypass enough flow through the recirculation line or turbine bypass lines to avoid the isobutane pump trip. This approach, however, would put a greater demand on the isobutane feed pump.

No other more demanding transients were experienced by the plant. Startup and shutdown proceeded smoothly as predicted in the original analysis.

Plant Output with Specified Component Performance. The deviations from design of the plant component performance and system operability have been noted earlier. The obvious question is: how was the performance of the plant affected? Since time did not permit the correction of the performance deviations, calculations were made to provide results as they would have been. This section reviews these deviations from specified and predicted performance and then assesses their impact on generator output.

The problems in system operability and component performance are:

1. The inability of the system to operate with design geofluid flow rate and turbine throttle values wide open. The cause of this problem was the inability of the isobutane feed pumps to keep up with the increased flow demand of the boilers. Indications are that this is a two-fold problem. First, the pumps appear to be operating below the specified flow-head curve. Second, there was a larger-thanexpected pressure drop between the isobutane pumps and the high-pressure boiler; experimental measurements and theoretical analysis both indicate that the pressure drop in the low preheater was around $20 \mathrm{psi}$ instead of $5 \mathrm{psi}$. These factors worked together to keep the pumps from supplying the boilers' demands.

2. It was noted early in the operation of the system that sufficient provisions were not 
made to eliminate entrained liquid from the boiler output. During operation, the boiler levels were lowered to minimize this entrainment (as discussed in the Boiler Entrainment Test section), but because of higher vapor generation rates, significant moisture remained in the boiler outlet flow. This moisture reduces turbine output by degrading the turbine efficiency and creating different mass flow rates through the turbines at a given boiler pressure.

3. The cooling water pumps did not produce design flow. This was probably because of improper installation. The pump pit in which the pumps were placed was not deep enough and the pumps were not at the proper distance from the wall of the pit. The maximum flow rate produced was approximately $78 \%$ of the design value. This created larger coolant temperature rises in the condenser and thereby raised the condensing temperature of the isobutane.

4. The cooling tower was also operating below its design expectation. The cold water leaving the tower was generally on the order of $10^{\circ} \mathrm{F}$ higher than predicted. This caused the condensing temperature of the isobutane to be higher also.

5. Deviation of the other plant components from specified performance caused small losses in system performance compared with the effects already mentioned. The geothermal heat exchanger performance varied substantially with the high-pressure boiler being the only exchanger performing worse than specified. It is felt that these deviations created little loss in turbine output. The condenser, on the other hand, directly affects the turbine back pressure and its $20 \%$ deviation from design performance created a back pressure, that was greater than the design value causing a decrease in turbine output. The fact that the turbine flows were somewhat larger than specified resulted in lower boiler pressures than design values at design flow and therefore contributed to lower enthalpy changes across the turbine and lower turbine output.
The effect of correcting these deficiencies is illustrated by considering the baseline run from the performance test series as described earlier. Table 8 gives the indicated power for that run along with the increments in power that each of the outlined deficiencies being corrected to design would produce. The increments in power associated with the five deficiencies were determined and added to give the total power if the system had been working as specified.

Achieving design flow would have increased the power by $2 \%$. In this case, the flow was $97 \%$ of design, but the boiler vapor was throttled substantially before introduction into the turbine. The moisture in the turbine is again a small value $(3 \%$ ) for this run. There was effectively no moisture in the high-pressure stage and around $20 \%$ in the low-pressure stage. The large losses in power were a result of the heat rejection process. The coolant pumps producing only $78 \%$ of design flow caused a 7\% decrease in power because of the rise in condenser temperature. The cooling tower deficiency gives a similar number.

Note that pretest estimates of the plant power with design fouling, design flows, $278^{\circ} \mathrm{F}$ inlet geofluid and $36^{\circ} \mathrm{F}$ wet bulb temperature were $5347 \mathrm{~kW}$, approximately the number given herein. Therefore, around 5.2 MW(e) would have been generated in the baseline run. Under these assumptions, the net plant power output would have been approximately $3632 \mathrm{~kW}$ including the power expended in the supply and injection system and around $3901 \mathrm{~kW}$ without including the production and injection pumps.

\section{Performance Analysis Conclusions}

The following summarizes the primary conclusions of the plant performance tests and makes recommendations concerning design of new binary-cycle plants.

1. The performance of the system, when corrected for the component performance values that were below specifications, was approximately as predicted.

2. Component problems were the cause of the low power generation. 


\begin{tabular}{|c|c|c|}
\hline & $\begin{array}{l}\text { Power } \\
(\mathrm{kW})\end{array}$ & $\begin{array}{c}\text { Possible } \\
\text { Power } \\
(\%) \\
\end{array}$ \\
\hline Generator output & 4010 & - \\
\hline \multicolumn{3}{|l|}{ Increment in power caused by defect } \\
\hline Failure to utilize design geofluid flow & 110 & 2 \\
\hline Moisture in turbine & 144 & 3 \\
\hline $\begin{array}{l}\text { Cooling water pumps not able to produce } \\
\text { specified flow }\end{array}$ & 380 & 7 \\
\hline $\begin{array}{l}\text { Cooling tower unable to produce specified cold } \\
\text { water temperature }\end{array}$ & 454 & 9 \\
\hline $\begin{array}{l}\text { Other components including heat exchangers, } \\
\text { turbine-generator } \\
\text { (power possible without defects) }\end{array}$ & 126 & 2 \\
\hline Total & $\overline{5224}$ & 100 \\
\hline Note: Value from pretest simulation: $5347 \mathrm{~kW}($ & ire $\left.=36^{\circ} \mathrm{F}\right)$ & \\
\hline
\end{tabular}

a. The combination of isobutane feed pumps producing 25 psi less heat at a given flow and a 15 to 20 psi larger pressure drop in the lower preheater at design conditions created a situation where the pumps were unable to provide the isobutane flow demanded by the boilers and design geofluid flow. This accounts for a power reduction of 2 to $3 \%$.

b. The boilers entrained some liquid in the exit vapor. This was carried into the turbine resulting in a degradation of turbine performance and reduced turbine output from 3 to $6 \%$.

c. The cooling water pumps produced only $78 \%$ of design flow because of improper installation of the pumps. This created a 5 to $6^{\circ} \mathrm{F}$ rise in condensing temperature in the condenser and a 7 to $9 \%$ decrease in turbine output. d. The cooling tower produced cold water 5 to $15^{\circ} \mathrm{F}$ hotter than specified. The higher end of this discrepancy is a result of operating with less than design air flow because of plant operational restriction with the cooling water treatment system. (Had the fans been operated at full speed, the deviation would have been 3 to $5^{\circ} \mathrm{F}$.) This produced a like rise in condensing temperature in the condenser and a degradation in turbine output of 8 to $16 \%$.

e. The heat exchangers appear to have performed near specified conditions with design fouling with the exception of the condenser. The condenser appeared to have approximately twice the design fouling (this number accounts for deviation between "asbuilt" and specified operating conditions as well as actual fouling). 
3. The system sensitivity to changes in geofluid inlet temperature and flow rate was essentially that calculated prior to operation of the plant.

4. Present knowledge of the thermodynamic and transport properties of isolation appear to be adequate in describing the performance of components and system.

5. The HTRI computer codes appear to be adequate in determining overall performance of the heat exchanger. Some small problems were noted but they did not change overall conclusions.

6. The transient problem in a turbine trip was caused by the low-flow trip on the isobutane feed pump.

The following recommendations are made after the experience with this plant.

1. In design of a new facility, the feed pump should be designed with a comfortable margin because it may need to overcome higher than design pressure drops, and any excess pressure can be handled by a control valve.

2. Proper design and construction of the heat rejection system is mandatory. This is where the greater share of the loss in power production from design occurred in this plant.

3. Care should be taken to ensure that any liquid entrained in boiler vapor flow is separated prior to removal of the vapor from the boiler.

4. The initial predictive methods were successful and could be used for any type of binary power cycle. The thermodynamic and transport properties are known adequately to describe the system behavior.

5. If the working fluid feed pump is to be protected with a low flow trip, there should be a time delay on the trip. There is a time during a turbine trip when there will be no flow demanded by the system. Pumps should be specified accordingly. 


\section{PLANT OPERATION}

This part of the report discusses the operation of the plant and supply and injection system. The first section concerns the primary systems of the plant (geothermal, isobutane, and cooling water) and their operation. These systems were described in the System Description section and detailed piping and instrumentation schematic drawings (P\&IDs) are included in Appendix A. The actual modes of operation are discussed here along with the operational problems encountered. The control system operation was discussed previously in the plant description section.

Next the plant auxiliary systems, consisting of the Cooling Water Treatment System (including blowdown transient), Instrumentation and Data Transmittal and Acquisition System, Firewater System, Instrument Air and Nitrogen Systems, and the Flare System, are described individually, and the operation of each is discussed.

Finally, the operation of the Geofluid Supply and Injection System is described.

\section{Operation of Primary Systems}

System Fill. The operation of the geothermal, isobutane, and cooling water systems begins with the filling of each system with the appropriate fluid. The geothermal and cooling water systems were initially filled with industrial water, and air in the system vented at the high points.

The isobutane system was initially inerted with nitrogen and the liquid isobutane was stored in two storage tanks. Filling the system with isobutane was accomplished by venting off the nitrogen pressure to about 1 psig, performing valve lineups, opening valves from the storage tanks and allowing isobutane to flow into the system piping until pressures in the storage tanks equal pressures in the system piping. Nitrogen and isobutane vapor were vented from the top of the piping system while liquid isobutane was added from the bottom. When no more isobutane would flow out of the storage tanks, the vapor compressor was started. This compressor took vapor from one storage tank, discharged it into the second storage tank to pressurize it, and forced liquid isobutane out and into the system piping. Because the isobutane vapors are heavier than nitrogen; the nitrogen was pushed out the high point vents as the system filled with liquid isobutane. Boilers were filled to the $50 \%$ full level and the condensate storage tank to the $60 \%$ level.

No problems were noted with the initial fill. The vapor compressor was adequate to move the isobutane into the system. The use of a vapor compressor to move the isobutane into the system following a shutdown appears to be a good procedure. This procedure did not work, however, when the system was pressurized and operating. In order to make up any losses of isobutane, the system first had to be shut down and cooled down. This was an awkward situation and would probably have impacted the performance of the plant had the plant been operated over a longer period of time. It is recommended that in future systems, provision be made to be able to make up isobutane shortages while the system is operating.

Plant Startup. The system was started as described from an overall viewpoint in the System Control Description section. The primary system operating variables monitored during startup were read out on a control panel in the control room as shown in Figure 38. Remotely activated valves could be operated from the control room to isolate any part of the system. The pumps for these systems and the turbine could also be operated from the control room.

Geothermal system startup was accomplished after filling the geothermal system, by first isolating the power plant from the S\&I system. The boost pumps were started against nearly closed hand valves. The valves were slowly opened as system pressure was maintained at 70 psig by industrial water pressure. The water was circulated within the system as a closed loop until hot water from the S\&I system was valved in for plant startup. The boost pumps were started by switches in the control room or locally at the pumps. It proved easier to start the pumps locally as all hand control valves were convenient. System pressure was regulated by a hand-operated butterfly valve (GY-819) downstream from the low-pressure preheater.

All temperature, pressure, and flow instrumentation functioned within acceptable industrial limits of 1 to $2 \%$. System pressure to the pump 


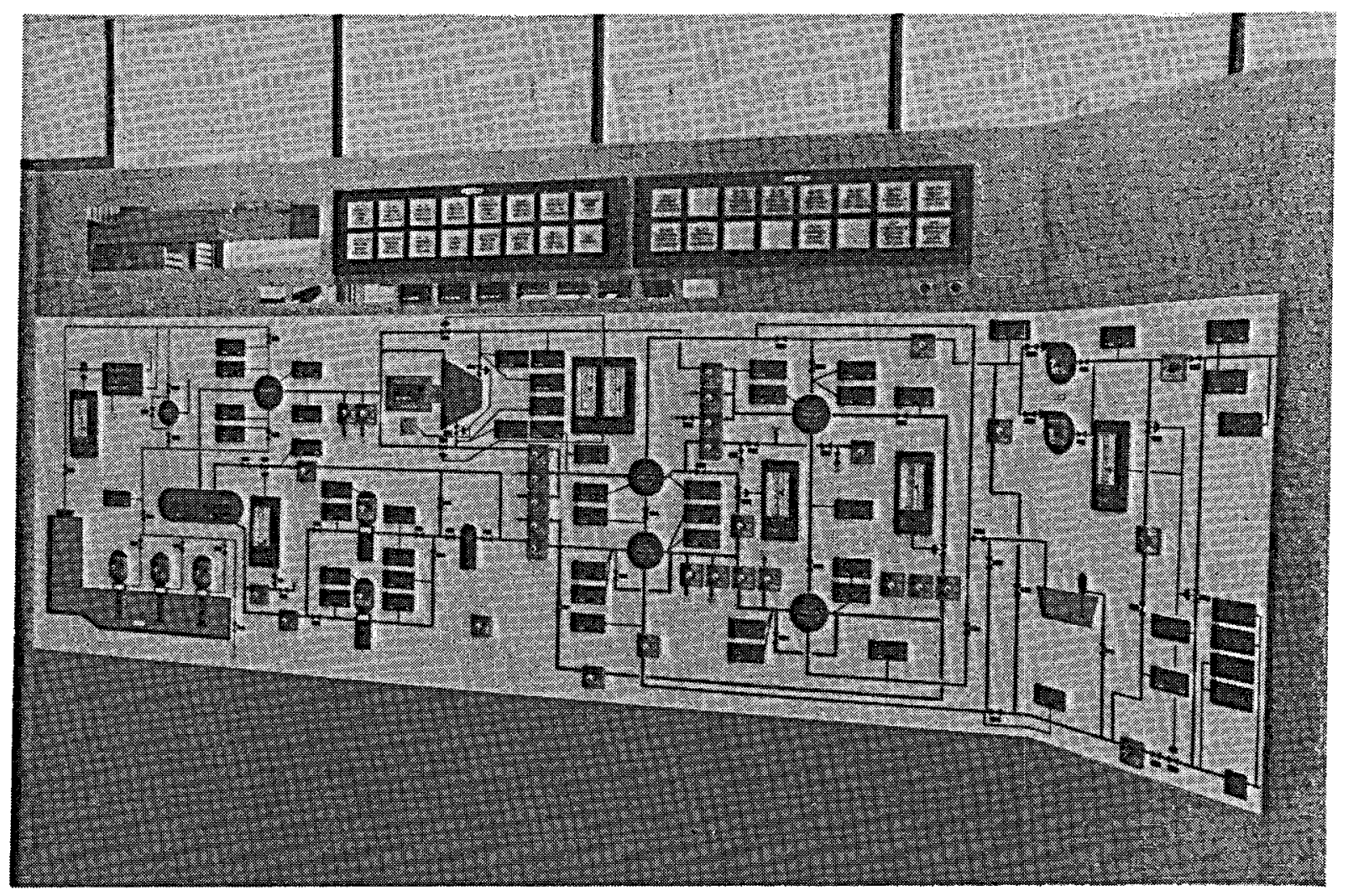

Figure 38. Facility control panel.

suction was maintained above 55 psig because a pressure switch with less than 40 psig would trip the pumps off line. This ensured the necessary boost pump net positive suction head and maintains the dissolved gases in solution. Line pressures were maintained by S\&I operators during plant operations.

The geothermal system worked smoothly with introduction of geothermal water to the plant occurring without incident. The boost pumps, however, tripped off on several occasions when the line pressure from the S\&I system was not maintained above 40 psig. The valves connecting the plant to the S\&I system were set to control on flow not pressure, thus allowing this to happen. This pressure would fall during a turbine trip when the temperature in the S\&I line would increase rapidly, thus causing the valve controlling flow to the pond to open and dump geofluid into the pond and the pressure in the line to drop.

The isobutane system pumps were started using switches in the control room. The control room operator communicated with the roving watch operator by sound-powered headphones. The pumps were started against nearly closed handoperated valves. The control room operator opened the control valve in the bypass line but closed the control valve to a position that maintained pump discharge pressure as the handoperated valve was opened by the roving watch operator. The control room operator adjusted the bypass control valve as needed to maintain flows and discharge pressures within prescribed limits. The pumps were shut down by low-flow safety trips or by pushing the stop buttons on the control panel. It was found that long periods of recirculation during warmup caused heating of the fluid in the condensate tank. Startup procedures for future binary plants must limit these warmup durations in order to prevent vapor formation in the pump inlet lines and pump cavitation or make sure that the bypass line is returned to the condenser inlet line.

Final plant startup was accomplished with the following steps:

1. All support systems such as air, nitrogen, flare, electrical, cooling water, and lube oil were started and operated. 
2. The supply and injection system was started with all geothermal water bypassing the plant.

3. The geothermal system within the plant was full and the booster pumps were circulating cold water through the plant and back to the section of the booster pump through a closed loop.

4. The isobutane pumps were circulating isobutane through the bypass line and all vapors were bypassing the turbine.

5. The control valves were gradually opened to allow a small amount of geothermal water into the plant. The heatup rate was manually controlled at $40^{\circ} \mathrm{F} / \mathrm{h}$.

When the plant was heated so that the temperature in the high-pressure boiler reached 230 to $250^{\circ} \mathrm{F}$, the temperature in the low-pressure boiler was 180 to $190^{\circ} \mathrm{F}$ and all the geothermal flow was flowing through the plant, the rest of the startup could be accomplished. The remaining procedure was to start the turbine and generator and close the generator breaker to put electricity into the grid. A summary of the procedural steps is as follows:

1. Open turbine drain valves and warmup valves to warm the piping between the bypass valves and the turbine. Reclose valves.

2. Slowly open turbine throttle valves to start rolling the turbine. Hold the turbine speed at $1500 \mathrm{rpm}$ for $1 \mathrm{~h}$. Increase speed in steps of 1000 to $4500 \mathrm{rpm}$ and hold for 15 to $30 \mathrm{~min}$ in order to let the system thermally stabilize at each step.

3. Increase speed to $7600 \mathrm{rpm}$ and allow the Woodward Governor to control the speed. Adjust the speed to synchronize the generator voltage with the grid voltage.

4. Close the generator breaker and adjust the line load to about $500 \mathrm{kVA}$. Gradually increase the load to full power output.

The startup procedures worked well. Startups generally were smooth and incident free.
Steady-State Plant Operation. Under normal, steady-state operation, after startup, the primary systems behaved very stably and the plant was operated with virtually no operator attention. Under conditions requiring high makeup cooling water use however, problems were encountered with the water treatment system. This system will be discussed in detail later in this report.

Plant upsets when the turbine tripped and switched to thermal loop operation were virtually impossible to control. The turbine throttle valves rapidly slammed shut and the turbine bypass valves that were actuated by high boiler pressure opened within seconds. The result was a rapid rise in boiler level followed by cutoff of boiler feed. This caused an instantaneous lack of flow through the isobutane pumps, causing them to trip off. The sudden loss of a heat sink for the geofluid propagated a temperature transient into the S\&I system and resulted in a rapid rise in feed temperature to the warm lime softener, necessitating manual shutdown of the water treatment system and a sudden dump of the geofluid to the pond, which caused the pressure to drop at the geofluid boost pumps, which then tripped. If plant shutdown resulted, it usually took $24 \mathrm{~h}$ to restart the S\&I system, the water treatment system, and complete thermal loop warmup in preparation for rolling the turbine. General recommendations for control-system modifications to improve this behavior are included in the Plant Performance section.

Another major problem encountered, which was not considered to be generic, concerned turbine bearing failures. The high-speed journal bearings of the turbine and the gear-reducer were replaced twice. The bearings failed by wiping of the babbit at a high spot created by improper installation of a temperature monitoring thermocouple. The first failure was due to oil contamination and the second due to isolation of the lube oil rundown tank (operator error) during a turbine coastdown that was caused by a power grid outage.

During cooling water pump operation, the discharge valves were adjusted to maintain flows at around $12,000 \mathrm{gpm}$. Flows higher than $12,000 \mathrm{gpm}$ produced high current to the pump motors. One pump motor (P-902) burned up and had to be rewound. The motors were protected with an automatic cutout when current values exceeded a setpoint. It was found during plant 
operation that the pump motors were of inadequate size in pumping the cooling water required for plant operation in its actual configuration. (Pump efficiencies were below design values for reasons discussed in the Pump Performance section.) Therefore, pump cutout limits could not be increased, but close attention was paid to pump motor amperage following this incident.

The cooling tower was a standard cross flow wet tower, and is described briefly in the Plant Description section. No operational problems were encountered with the cooling tower.

Plant Shutdown. Three detailed operating procedures were written to shut down the plant. One procedure was used to unload the generator, trip the generator breaker, and shut the turbine down. The plant was then operating as a thermal loop with the turbine bypass. Another procedure was used to cool the plant down to a cold standby condition. A third procedure was used to drain isobutane back to the storage tanks and inert the system piping with nitrogen. All three procedures were revised after the power run in November 1981 to reflect discovered deficiencies, more details, and the as-built plant, and instrument numbers. The revised procedures were followed to shut down the plant in June 1982. The shutdown was accomplished without incident.

\section{Operation of Auxiliary Plant Systems}

Water Treatment System. The location of a geothermal power plant is determined by the location of the geothermal resource; cooling requirements must be satisfied by the water available at the location. Many of the geothermal resources are located in water-short regions or regions where surface and groundwaters are high in silica and salinity. The Raft River Pilot Power Plant was located in such a region. Treated concentrated geothermal water is used for plant cooling. This was the first known attempt to use treated geothermal water for cooling (other than condensate obtained in steam plants). Earlier research had determined that the treatment system originally designed for the plant was not adequate because of the peculiarities of the geothermal water. A modified treatment was developed and used during the plant startup.

The primary purpose of the water treatment system is to purify a portion of the geothermal fluid leaving the plant in order to provide good quality water for use in the plant cooling system for heat removal from the isobutane working fluid. Figure 39 is a simplified flow diagram of the water treatment system. The water treatment plant consisted of three separate but integrated systems

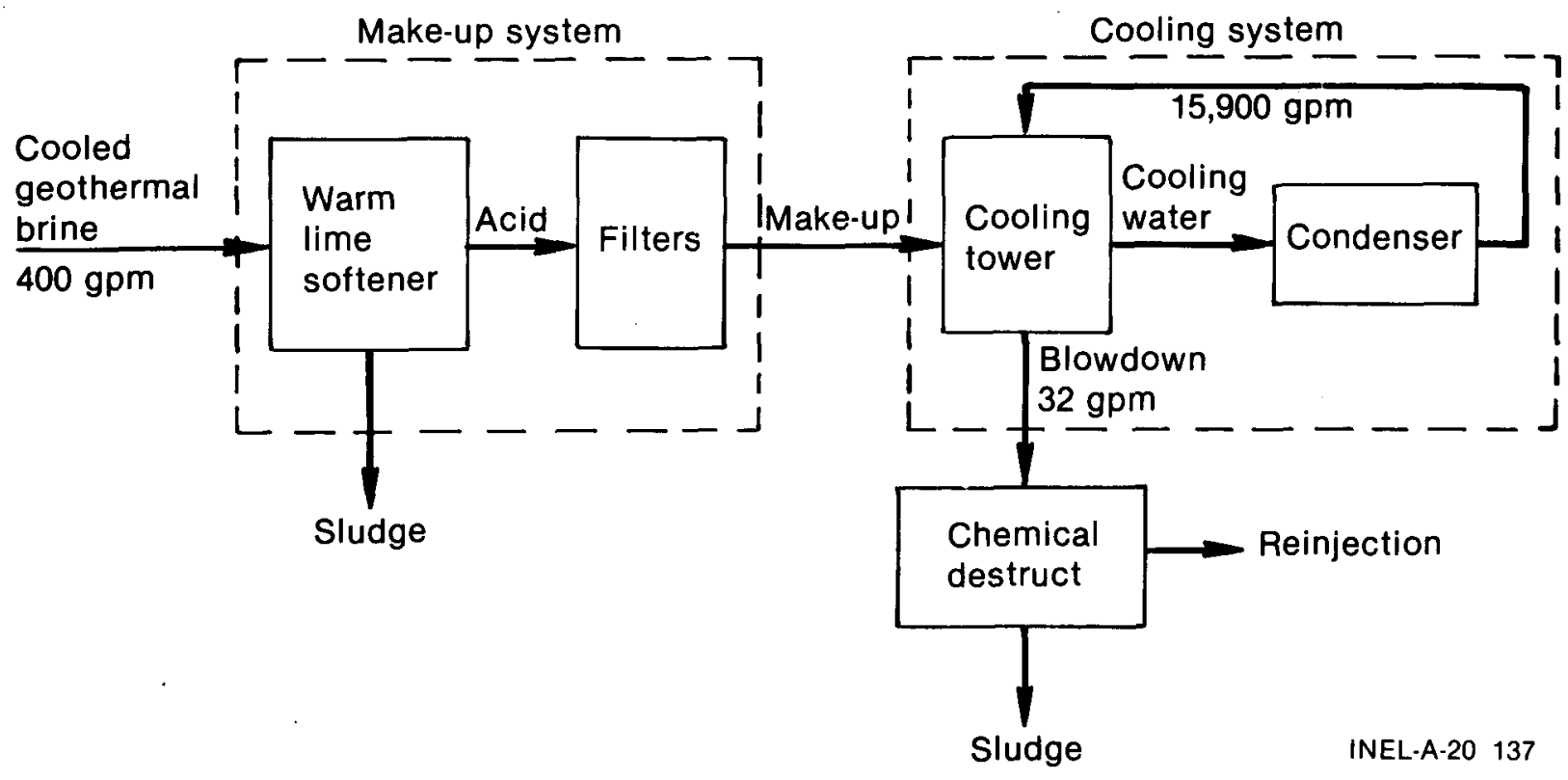

Figure 39. Flow diagram of the water treatment system. 
(makeup, cooling, and blowdown) ${ }^{\mathrm{a}}$ that were designed to balance flow rate and water quality to maximize plant performance and minimize environmental impact.

The makeup volume and blowdown volume were related by the cycles of concentration in the cooling tower. "Cycles of concentration" is defined as the ratio of chloride in the circulating cooling water to chloride in the cooling water makeup. The higher the cycles of concentration, the lower the resulting blowdown flow, and consequently, the lower the makeup flow requirement. The makeup unit design was modified during construction to allow operation at a minimum of five cycles ( $400 \mathrm{gpm})$; the blowdown unit was designed for flows corresponding to a minimum of eight cycles $(32 \mathrm{gpm})$. This means that unless the blowdown was dumped to a pond, the minimum cycles of concentration were controlled by the capacity of the blowdown unit (eight cycles).

Heat Exchanger Passivation. At the time of the design of the system, designers anticipated that

a. In an evaporative cooling system, the makeup rate is equal to the losses from the system by evaporation, blowdown, and drift. A stream of cooling water leaving the system (blowdown) is necessary to limit the concentration of minerals that would otherwise occur and result in precipitation. The relationship between the makeup rate $M$, the blowdown rate $B$, and the cycles of concentration $C$, is $C=M / B$ for negligible drift. water treatment of the industrial water could be used to eliminate corrosion of a carbon steel heat exchanger. It was later decided that geofluid would have to be used instead of industrial water. A carbon steel heat exchanger was already installed, so that the metal had to be protected by passivation in order for the chemical treatment program to work. This was done by forming a gamma iron oxide film on the metal surface. Several attempts were made to passivate the heat exchanger but failed due to mechanical difficulties encountered during the cleaning procedure. The passivation procedure used is described in Table 9.

Failure to passivate results in high iron dissolution rates and rapid scale buildup within the condenser (control of cooling water purity is impossible and scale buildup occurs within several days). A clean (nonrusty) surface is required when the passivation steps are started. This film was maintained by the water treatment process but was completely lost when the $\mathrm{pH}$ dropped below 5.5.

Makeup System. The makeup unit, consisting of the warm lime softener (silica and calcium removal), chemical feed pumps, and tanks, was designed to treat $400 \mathrm{gpm}$ of geothermal power plant effluent. Anthracite filters were included in the system for particle removal.

\section{Table 9. Condenser cleaning and passivating procedure}

1. Circulate a caustic solution through the system for $4 \mathrm{~h} \mathrm{(4 \% ).} \mathrm{This} \mathrm{would} \mathrm{remove} \mathrm{the} \mathrm{organic}$ material and help break up the scale deposits.

2. Flush.

3. Circulate inhibited phosphoric acid solution containing surfactant and $50 \mathrm{ppm}$ Betz 426 at a pH of 1 to 2 for $4 \mathrm{~h}$. This should break up the rest of the scale and should clean at least $90 \%$ of the surface-equivalent to mechanical cleaning.

4. Drain down with nitrogen in the condenser.

5. Flush.

6. Circulate a solution of $\mathrm{pH} 8$ to 8.5 adjusted with soda ash for $2 \mathrm{~h}$.

7. Flush.

8. Circulate a passivating solution of $200 \mathrm{ppm}$ Betz 2040 and $100 \mathrm{ppm}$ Betz 2020 through the condenser for five days; drain, dry, and place under a 2 to 5 psi nitrogen blanket. 
Table 10. Nominal chemical composition of makeup water

\begin{tabular}{ll} 
Temperature & $140^{\circ} \mathrm{F}$ \\
$\mathrm{pH}$ & 8.3 \\
$\mathrm{CL}^{-}$ & $1000 \mathrm{ppm}$ \\
$\mathrm{F}^{-}$ & $8.4 \mathrm{ppm}$ \\
$\mathrm{SO}^{-4}$ & $82 \mathrm{ppm}$ \\
$\mathrm{Na}^{+}$ & $600 \mathrm{ppm}$ \\
$\mathrm{Calcium}^{-}$ & $139 \mathrm{ppm}$ as $\mathrm{CaCO}_{3}$ \\
Total hardness & $140 \mathrm{ppm}$ as $\mathrm{CaCO}_{3}$ \\
SiO & \\
Total alkalinity & $180 \mathrm{ppm}$ \\
Conductivity & $120 \mathrm{ppm}$ as $\mathrm{CaCO}_{3}$ \\
\hline
\end{tabular}

Cooled geothermal brine was used as the cooling fluid due to the lack of adequate surface water. The nominal chemical composition of the plant effluent (makeup water entering the softener) is shown in Table 10.

Reducing and limiting silica and calcium prevented scale deposition on the condenser tubes. Magnesium chloride and lime were added to the makeup water to precipitate silica. Soda ash was added to precipitate calcium. A high molecular weight anionic polymer was added to enhance coagulation and settling of the precipitate. The precipitate sludge was periodically pumped from the softener to nearby evaporation ponds. Chemical control on the product water prior to introduction to the cooling system was: silica approximately 4 to $6 \mathrm{ppm}$, and calcium approximately $20 \mathrm{ppm}$.

Blowdown System. The blowdown system consisted of a precipitator and associated chemical feed pumps and tanks. The unit was designed for a maximum flow rate of $\mathbf{3 2} \mathrm{gpm}$ and removed from the blowdown water chemical species that were environmentally harmful (copper, zinc, and iron) or posed a plugging problem from reinjection (phosphate). Ferrous sulfate and lime were added to the blowdown water, forming metal hydroxides and metal phosphates that are insoluble at a high pH. A moderately high molecular weight cationic polymer was also added to aid in coagulation and settling in the precipitator. The product water was pumped to a holding pond for reinjection while the sludge was pumped to a holding tank for proper surface disposal.

Water Treatment System Performance. After resolving several problems and making modifications, the system was able to maintain the cycles of concentration of the water between 5 and 30. During the cool hours of the day, the system could maintain five cycles of concentration; but as the day grew hotter, the cycles of concentration would also increase. With the iron present, precipitation occurred at less than 20 cycles of concentration, seriously limiting the effectiveness of the cooling system. This behavior is attributable to the inability of the maximum makeup water flow that could be handled by the water treatment system, to provide for the higher evaporation rates at hotter ambient temperatures. Temperature also affected the ability of the system to operate since silica removal was not sufficient below $110^{\circ} \mathrm{F}$, and the makeup pump could not handle temperatures greater than $160^{\circ} \mathrm{F}$. This limited operation during 
very cold weather and completely shut down the pretreatment system when a sudden geofluid bypass of the plant occurred. During operation, there were many $\mathrm{pH}$ upsets that resulted in the $\mathrm{pH}$ dropping below 5.5, thus causing the loss of the passivating film.

Overall, it is concluded that this was not a fair test of the use of geofluid for cooling water. The results were dominated by the corrosion of the carbon steel. If the tube side of the condenser had been made of copper-nickel, ferritic stainless steels, or admiralty brass, and the piping were protected with an organic coating, it would have greatly improved the water treatment problem by increasing the allowable cycles of concentration by more than 10 times, and by decreasing and/or the amount of chemicals needed.

Instrumentation and Data Transmittal System. There are 213 remote instruments in the plant. The remote instrumentation measured the following values: temperature, pressure, flow, valve position, differential pressure, generator output, turbine vibration, liquid levels, and turbine speed.

The electronic transmitters sent signals to the control room which were displayed on a graphic panel (Figure 38 ) for indication and control, or to a signal conditioning transmitter rack where the signals were prepared and corrected for the computer.

Besides sending information to the computer to be displayed and stored, 58 instrument signals went to panel-mounted meters and 6 provided signals for automatic valve controllers used in plant operation on the graphic display panel. Ninety-five instruments were wired into a patch board on the test and diagnostic console where they could be patched into chart recorders or panel-mounted meters for indication and records.

The PDP 11/34 data acquisition computer manufactured by Digital Corporation received 256 instrument inputs. During testing, 213 inputs were used: 55 for pressure, 100 for temperature, 22 for flow, 6 for differential pressure, 9 for valve position, 4 for tank levels, 1 was turbine speed, 6 for generator outputs, and 10 for generator drive train vibration.

The information sent to the computer was updated constantly to provide accurate data and respond to any change in plant conditions. The data in the computer was monitored from the operator terminals and provided alarm functions for plant equipment.

There were four problems encountered with the instrumentation:

1. Extreme temperature changes and the sensitivity of the transmitters to temperature changes caused instrument drift in all the transmitted results.

2. Freezing temperatures caused some initial damage to all the transmitters. Heat tape and insulation were subsequently installed for protection.

3. The RTD outputs to the control panel were not corrected (as were the same inputs to the computer) thus, temperature measurement were at times misleading. At several locations the original RTDs were replaced with platium RTDs which required no correction and thus provided an accurate indication on the control panel.

4. Bearing failures in turbine flowmeters were a major problem. The bearings were cooled and lubricated by the fluids that flowed through the meters and were susceptible to corrosion. Because of water exposure during hydrotesting, the bearings corroded and failed before the plant was started up. Repairs were made by removing the flowmeters from the pipeline, replacing the failed bearings, and reinstalling the flowmeters. These instruments should have been removed and replaced by spools during hydrotesting and flushing.

Firewater System. A schematic of the firewater system is shown in Appendix A. The firewater system consisted of two fire pumps, seven fire hydrants, seven deluge systems, four wet-pipe sprinkler systems, and a 300,000-gal water storage tank. Each fire hydrant had a nearby storage house for hoses and equipment. The fire system also included a Halon gas system located in the control room. The purpose of the Halon system was to stop electrical fires that might have occurred in the control room floor. 
The firewater system was in operation when all pipelines were full of water and in a standby condition. Two fire pumps, each with a rated capacity of $2500 \mathrm{gpm}$, were activated when water pressure dropped in the pipeline downstream of the pumps. The electric firewater pump (with a 300-hp motor) started when water pressure dropped below 85 psig. The diesel firewater pump started when water pressure dropped below $65 \mathrm{psig}$. Water was supplied to the pumps from the 300,000-gal storage tank. The storage tank also supplied water to the industrial and domestic water systems. The water pressure was maintained at 115 to $125 \mathrm{psig}$ by a jockey pump and surge tank. Water pressures were reduced by pressure regulators to $60 \mathrm{psig}$ for domestic use.

Testing of the firewater system was originally performed by construction personnel. Five deluge systems in the process area, one in the cooling tower, and one in the substation were tested. Personnel from INEL Fire Engineering observed and approved the original tests. Fire Engineering personnel have since performed annual flow tests from each fire hydrant. The annual testing also included activating each alarm on the alarm panel from individual test stations. Operations personnel tested the electric and diesel fire pumps on a weekly basis. A surge suppressor tank was installed in the firewater pumphouse to mitigate the hydraulic surge when the firewater pumps turned on. The electric firewater pump started every time the water pressure dropped from the normal 115 to 125 to $85 \mathrm{psig}$. This happened periodically when water was used to fill chemical feed tanks in the water treatment building. No deficiencies in the fire-protection system were detected.

Instrument Air and Nitrogen System. P\&ID of the instrument air and nitrogen system is shown in Appendix A. The instrument air system supplied compressed air for instrument and valve control and for utility use. The air system was backed up by nitrogen in case the air compressor failed. The nitrogen was also used to purge air or isobutane from the vessels and piping to give an inert atmosphere. The nitrogen was stored in two 3000-gal tanks at 50 to $960 \mathrm{psig}$. The pressure was reduced to $150 \mathrm{psig}$ out of the tanks and further reduced to 10 to $25 \mathrm{psig}$ as required for purging operations. Nitrogen at 500 psig was supplied to the turbine lube oil system to pressurize the rundown tank and control-oil accumulator with enough pressure to keep oil flowing to the bear- ings in case power fails to the lube oil pumps. Nitrogen at 90 psig flowed into the air lines when air pressure dropped below 90 psig. The air and nitrogen system worked well except when the air compressor wore out and had to be overhauled. Water in the air lines caused problems during freezing weather. Solenoid valves on the air dryers corroded, malfunctioned, and required replacement. Water absorbent materials in the air dryers had to be replaced twice.

It is recommended that more care be taken in future designs to prevent water from getting into the air-nitrogen system.

Flare System. A P\&ID of the flare system is shown in Appendix A. The purpose of the flare system was to safely burn off the isobutane vapors from the isobutane process and storage systems. The isobutane vapors were vented to the flare during both fill and drain operations. The flare was normally on standby. On standby, the propane storage tank provided a constant flow of gas to the pilot burner. The pilot flame burned continuously during all plant operations where isobutane was being used. The flare system had a "knockout" tank filled with antifreeze solution. The isobutane from the plant passed through the knockout tank on its way to the flare. The knockout tank prevented backflow of air and gas mixtures into the plant. The knockout tank was supplied with carbon dioxide from the inert gas generator. The inert gas, together with a flame arrester, prevented combustion of flammable gases inside the pipe between the knockout drum and the flare burner. No problems were encountered with the flare system.

\section{Supply and Injection System Operations}

The purpose of the supply and injection (S\&I) system was to supply hot geothermal water to the 5 -MW(e) pilot plant. Figure 40 shows the relative location of the wells and pipeline to the plant. The average temperature of production well water was $280^{\circ} \mathrm{F}$. The amount of water capable of being produced by each well varied from $55 \mathrm{gpm}$ with artesian flow to $1280 \mathrm{gpm}$ with a submersible pump set at approximately $2000 \mathrm{ft}$ deep. The production and injection wells and plant were linked by underground transite (cement-asbestos) piping. The system is described briefly in the plant 


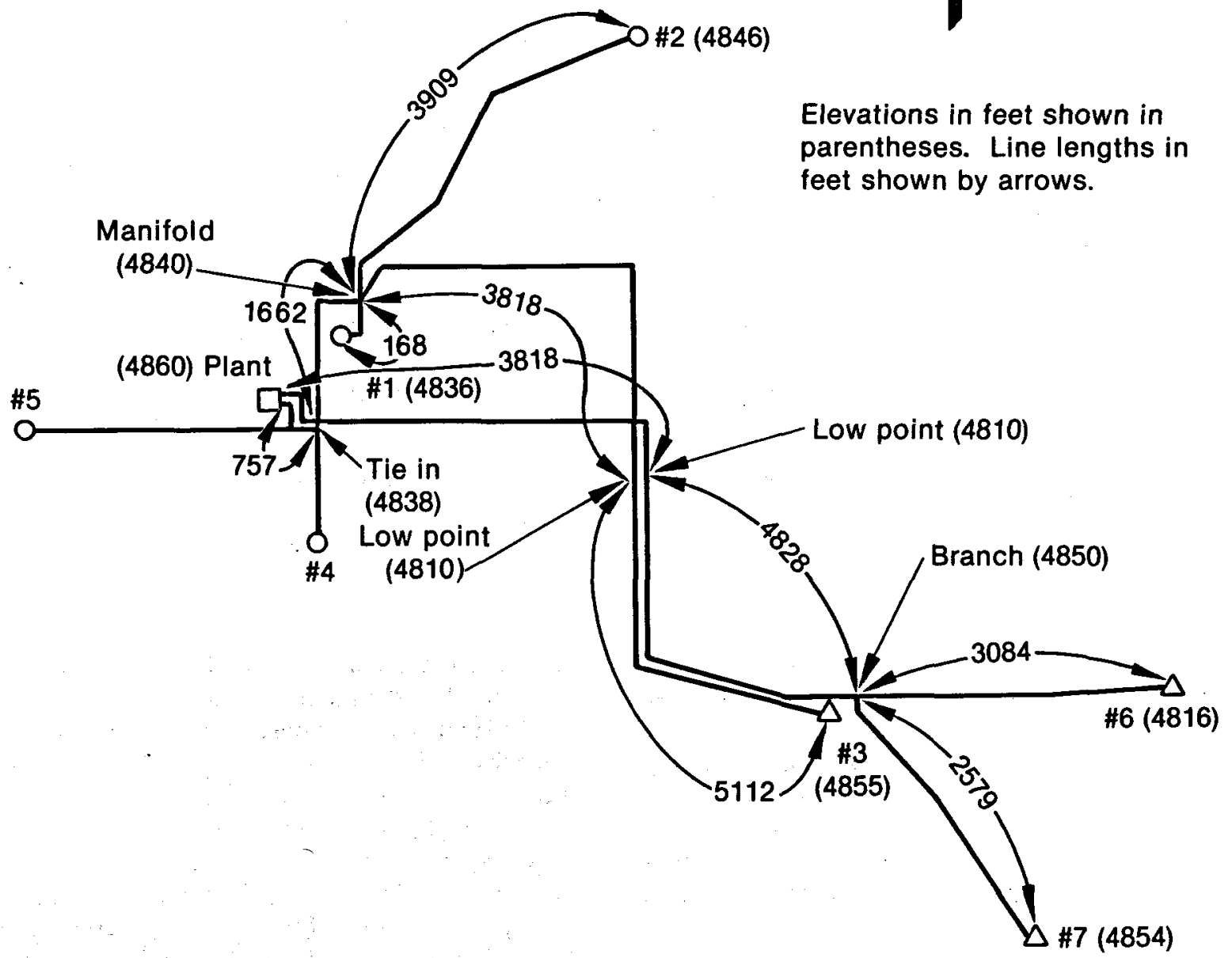

INEL 33200

Figure 40. Pipelines for geofluid fluid supply and injection system.

description section. Table 11 presents summarytype information about the wells. Reference 9 contains more detailed information about the individual wells and their drawdown characteristics. Wells RRGP-1, RRGP-2, and RRGP-3 were pumped and used to supply the geofluid to the plant. The flow leaving the plant was pumped into Wells RRGI-6 and RRGI-7. Well RRGE-4 was inoperable. When a shutdown occurred after a long period of operation, the pumped wells (RRGP-1, -2, and -3) had been drawn down to the point at which artesion flow to warm the lines was not practical. At this time Well RRGP-5 was used in artesian flow to warm all of the lines prior to startup of the production pumps.
Each production well had instruments to indicate and record temperature, pressure, and flow. Each well had a pump with appropriate switchgear and an automatic control valve to maintain constant flow. One control valve at Well Site 6 was used to maintain constant line pressure. The system worked well when adjustments were made slowly.

The two areas which caused the greatest operational problems were the supply pumps and the cement-asbestos piping.

Production Pumps. Over the past five years, both submersible and line-shaft pumps have been used in 
Table 11. Supply and injection well summary (07/26/82)

\begin{tabular}{|c|c|c|c|c|c|c|c|c|c|}
\hline \multirow[b]{2}{*}{$\begin{array}{c}\text { Well } \\
\text { Number } \\
\end{array}$} & \multirow[b]{2}{*}{ Well Type } & \multirow{2}{*}{$\begin{array}{c}\text { Maximum } \\
\text { Artesian } \\
\text { Flow } \\
\text { (gpm) } \\
\end{array}$} & \multirow{2}{*}{$\begin{array}{c}\text { Well } \\
\text { Head } \\
\text { Pressure } \\
\text { (psig) }\end{array}$} & \multirow{2}{*}{$\begin{array}{c}\begin{array}{c}\text { Bottom } \\
\text { Hole } \\
\text { Temperature } \\
\left({ }^{\circ} \mathbf{F}\right)\end{array} \\
\end{array}$} & \multirow[b]{2}{*}{$\begin{array}{c}\text { Flow } \\
\text { Temperature } \\
\left({ }^{\circ} \mathrm{F}\right)\end{array}$} & \multirow[b]{2}{*}{$\begin{array}{c}\text { Well } \\
\text { Depth } \\
\text { (ft) }\end{array}$} & \multirow[b]{2}{*}{$\begin{array}{l}\text { Check } \\
\text { Valve } \\
\text { (ft) }\end{array}$} & \multicolumn{2}{|c|}{ Casing Size } \\
\hline & & & & & & & & $\begin{array}{l}\text { Diameter } \\
\text { (in.) }\end{array}$ & $\begin{array}{c}\text { Depth } \\
\text { (ft) }\end{array}$ \\
\hline RRGP-1 & Production & 300 & 134 & 294 & 279 & 4989 & 4509.5 & $\begin{array}{l}30 \\
20 \\
13-5 / 8\end{array}$ & $\begin{array}{r}40 \\
901 \\
3623\end{array}$ \\
\hline RRGP-2 & Production & 250 & 121 & 296 & 280 & 6543 & 1884 & $\begin{array}{l}30 \\
20 \\
13-5 / 8\end{array}$ & $\begin{array}{r}40 \\
901 \\
4227\end{array}$ \\
\hline RRGP-3 & Production & 200 & 102 & 298 & 296 & $\begin{array}{l}\text { A-5853 } \\
\text { B-5532 } \\
\text { C-5917 }\end{array}$ & 1171 & $\begin{array}{l}20 \\
13-5 / 8 \\
9-5 / 8\end{array}$ & $\begin{array}{r}120 \\
1383 \\
3565\end{array}$ \\
\hline RRGE- $4^{\mathrm{a}}$ & Experimental & 55 & 126 & 273 & 248 & $\begin{array}{l}\text { A-4911 } \\
\text { B-5115 }\end{array}$ & No packer & $\begin{array}{l}20 \\
13-5 / 8 \\
9-5 / 8\end{array}$ & $\begin{array}{r}150 \\
1915 \\
3408\end{array}$ \\
\hline RRGP-5 & Production & 200 & 110 & 168 & 257 & $\begin{array}{l}\text { A-4911 } \\
\text { B-4925 }\end{array}$ & 1284 & $\begin{array}{l}20 \\
13-4 / 8 \\
9-4 / 8\end{array}$ & $\begin{array}{r}150 \\
1510 \\
3408\end{array}$ \\
\hline RRGI-6 & Injection & - & 38 & 253 & - & 3888 & No packer & $13-5 / 8$ & 1698 \\
\hline RRGI-7 & Injection & - & 4 & 162 & - & 3444 & No packer & $13-5 / 8$ & 2044 \\
\hline
\end{tabular}

the Raft River wells. The pumps installed in the Raft River geothermal wells were tested to determine maximum flows and associated electrical power consumption. The testing was part of a national pump development project for developing pumps for geothermal use. The test results were coordinated with personnel from Los Alamos National Laboratory who compared results from pumps being tested at other geothermal sites.

The first pump installed in Well RRGP-1 was a submersible pump manufactured by REDA Co. The pump was powered by two motors of $160 \mathrm{hp}$ each to produce a maximum flow rate of $1500 \mathrm{gpm}$. The pump proved too large for the well and was removed after $112 \mathrm{~h}$ of operation. REDA submersible pumps were also installed in Wells 3 and 5. (Note that for the plant performance testing Well 5 was used only in the artesian-flow mode for pipe warmup.) Pump failures occurred with the electrical cable or motor shorting out, or the pumps seizing and causing high current trips. In the case of the electrical short, the seals in the pump motors would allow water to leak into the electrical sections and short out the motors. Centrilift pumps were next installed in Wells 1,2 , and 3. Those pumps also failed by shorting out in their motors or lead-in electrical cables. The submersible pumps were later replaced with line shaft pumps having their electric motors located above ground. This eliminated the electrical short problem, but the pumps could not be set as deep as the submersible pumps, which limited pumping capacity and well drawdown. This limitation was not a problem during the short period of operation, though, and could probably have been rectified by making the line shaft longer and the motor larger. One Peerless line shaft pump had to be replaced because of worn bearings $1200 \mathrm{~h}$ later. The other two have operated for $1600 \mathrm{~h}$ and were expected to be operable for another $1600 \mathrm{~h}$.

These Peerless line shaft pumps, which were in Wells 1, 2, and 3 for the testing period, had a specially designed lubrication system to supply a soluble lubricant and water to the shaft bearings. The pump in Well 3 had Teflon water lubricated bearings and the other pumps had lead bronze alloy bearings. The lubrication system consisted of a storage tank for the water-soluble lubricant, a Milton-Roy metering pump, in-line filters, pressure gauges, and flowmeters. The lubricant was pumped at about 0.5 to $1 \mathrm{gpm}$ into the packing box at the top of the pump shaft seal. The lubricant and water mixture flowed down the shaft to lubricate bearings located at 5-ft intervals. Table 12 summarizes the history of pumps installed and removed from the production wells at the Raft River site including those in place during the test period. 
Table 12. Supply and injection system pump history

\begin{tabular}{|c|c|c|c|c|c|c|c|c|}
\hline Location & Manufacturer & $\begin{array}{c}\text { Motors } \\
\text { (hp) } \\
\end{array}$ & $\begin{array}{c}\text { Date } \\
\text { Installed } \\
\end{array}$ & $\begin{array}{c}\text { Set } \\
\text { Depth } \\
\text { (ft) }\end{array}$ & $\begin{array}{c}\text { Date } \\
\text { Removed }\end{array}$ & $\begin{array}{l}\text { Total } \\
\text { OPS } \\
\text { Time } \\
\end{array}$ & Reason for Removal & Remarks \\
\hline RRGE-1 & REDA & (2) 160 & $11 / 20 / 75$ & 620 & $05 / 21 / 76$ & $112 \mathrm{~h}$ & Too large for well & Did not fail \\
\hline RRGE-1 & Centrilift & $\begin{array}{l}\text { (1) } 400 \\
\text { (1) } 250\end{array}$ & $09 / 09 / 79$ & 2021 & $01 / 16 / 80$ & $114 \mathrm{~h}$ & $\begin{array}{l}\text { Short downhole during } \\
\text { test on } 01 / 07 / 80\end{array}$ & $\begin{array}{l}\text { Manufacturer reports } \\
\text { leaking seals in motors }\end{array}$ \\
\hline RRGE-I & Centrilift & (1) 400 & $04 / 11 / 80$ & 2021 & $08 / 07 / 80$ & $8.5 \mathrm{~h}$ & Short downhole & $\begin{array}{l}\text { Failed on } 05 / 13 / 80 \text {, low } \\
\text { resistance, failed after } \\
1 \text { min }\end{array}$ \\
\hline RRGE-i & $\begin{array}{l}\text { REDA } \\
\text { (Loaner) }\end{array}$ & (3) 200 & $08 / 13 / 80$ & 2078 & $10 / 17 / 80$ & $541.5 \mathrm{~h}$ & $\begin{array}{l}\text { Short downhole on } \\
10 / 11 / 80\end{array}$ & $\begin{array}{l}\text { Leads in J-box shorted } \\
\text { on } 10 / 11 / 80 \text {, fuse blown }\end{array}$ \\
\hline RRGE-1 & REDA & (2) 340 & $10 / 22 / 80$ & 1976 & $12 / 16 / 80$ & $4.25 \mathrm{~h}$ & $\begin{array}{l}\text { Electrical short downhole } \\
12 / 03 / 80\end{array}$ & $\begin{array}{l}\text { Resistance on electrical } \\
\text { leads deteriorated }\end{array}$ \\
\hline RRGE-1 & Peerless & 500 & $08 / 05 / 81$ & 980 & $07 / 23 / 82$ & $1643 \mathrm{~h}$ & $\begin{array}{l}\text { To log the well during } \\
\text { injection testing }\end{array}$ & $\begin{array}{l}\text { Soluble oil caused } \\
\text { deposits on shaft } \\
\text { bearings }\end{array}$ \\
\hline RRGE-2 & Peerless & 250 & $04 / 28 / 78$ & 802 & $08 / 22 / 79$ & $1160 \mathrm{~h}$ & $\begin{array}{l}\text { To install Centrilift } \\
\text { submersible pump }\end{array}$ & $\begin{array}{l}\text { Tail shaft bearing was } \\
\text { worn thin }\end{array}$ \\
\hline RRGE-2 & Centrilift & $\begin{array}{l}\text { (1) } 400 \\
\text { (1) } 100\end{array}$ & $09 / 21 / 79$ & 1860 & $03 / 25 / 80$ & 0 & $\begin{array}{l}\text { Short downhole on } \\
01 / 10 / 80\end{array}$ & $\begin{array}{l}\text { Manufacturer reports } \\
\text { failure from damaged } \\
\text { cable head }\end{array}$ \\
\hline RRGE-2 & Centrilift & $\begin{array}{l}\text { (1) } 400 \\
\text { (1) } 100\end{array}$ & $04 / 23 / 80$ & 1884 & $04 / 29 / 80$ & $11 \mathrm{~min}$ & $\begin{array}{l}\text { Short downhole on } \\
04 / 25 / 80\end{array}$ & $\begin{array}{l}\text { Manufacturer reports } \\
\text { failure due to stator burn }\end{array}$ \\
\hline RRGE-2 & Centrilift & $\begin{array}{l}\text { (1) } 400 \\
\text { (1) } 100\end{array}$ & $05 / 06 / 80$ & 1884 & $07 / 30 / 80$ & $14 \min$ & $\begin{array}{l}\text { Short downhole on } \\
05 / 07 / 80\end{array}$ & - \\
\hline RRGE-2 & Peerless & 350 & $07 / 29 / 81$ & 980 & - & $1342 \mathrm{~h}$ & - & Pump is still installed \\
\hline RRGE-3 & REDA & (2) 160 & $05 / 07 / 77$ & 773.3 & $05 / 23 / 78$ & $\begin{array}{c}1359 \mathrm{~h} \\
.\end{array}$ & $\begin{array}{l}\text { Power cable short at } \\
\text { grating on } 04 / 10 / 78\end{array}$ & - \\
\hline RRGE-3 & Centrilift & 250 & $09 / 26 / 79$ & 1110 & $03 / 23 / 80$ & $\cdots$ & $\begin{array}{l}\text { Manufacturer recom- } \\
\text { mended pulling the } \\
\text { pump }\end{array}$ & $\begin{array}{l}\text { Pump modified by } \\
\text { manufacturer based on } 1 \\
\text { and } 2 \text { failure }\end{array}$ \\
\hline RRGE-3 & Centrilift & 250 & $04 / 13 / 80$ & 1042 & $08 / 01 / 80$ & $814 h$ & $\begin{array}{l}\text { Short downhole on } \\
06 / 17 / 80\end{array}$ & - \\
\hline RRGE-3 & Peerless & $\quad 250$ & $08 / 02 / 81$ & 996 & - & $1485 \mathrm{~h}$ & - & Pump is still installed \\
\hline RRGP-5 & REDA & (2) 160 & $03 / 10 / 79$ & 1000 & $11 / 03 / 79$ & $\mathbf{5 6 8 h}$ & $\begin{array}{l}\text { Fracture stimulation of } \\
\text { well, did not fail }\end{array}$ & $\begin{array}{l}\text { Manufacturer reported } \\
\text { bad bearing sin pump, } \\
\text { bad electric cable }\end{array}$ \\
\hline RRGP-5 & REDA & (2) 160 & $12 / 14 / 79$ & 1098 & $04 / 15 / 80$ & $85 \mathrm{~h}$ & $\begin{array}{l}\text { Short downhole on } \\
\mathbf{0 3 / 3 0 / 8 0}\end{array}$ & $\begin{array}{l}\text { Motor burnt, pump } \\
\text { gutted, cable damage } \\
\text { and wear due to sand }\end{array}$ \\
\hline RRGP-5 & REDA & (2) 160 & $08 / 14 / 80$ & 1153 & $07 / 21 / 82$ & $61.3 \mathrm{~h}$ & $\begin{array}{l}\text { Short downhole on } \\
03 / 16 / 81\end{array}$ & $\begin{array}{l}\text { Pump wore out from } \\
\text { pumping sand }\end{array}$ \\
\hline
\end{tabular}


Injection Pumps. No major problems were encountered with the injection well pumps. Ingersoll-Rand pumps were installed at Wells 6 and 7 to inject the water down the wells. The same pumps were later moved to Well 7 for regular injection during S\&I system operation. A 300-hp vertical-turbine pump was installed in the line at Well 6 for regular injection operations. The Ingersoll-Rand pumps at Well 7 were later replaced with a Johnston vertical-turbine pump.

A centrifugal separator at the section of the reinjection pump and filters on the discharge of the reinjection pump helped remove sand from the geofluid. The centrifugal separator worked best at high flow rates but was not needed after system operation was changed to dump the geofluid to the pond before reinjection. Four filters were necessary in the filter system and were changed every two weeks.

Cement-Asbestos Piping. The supply and injection system piping was a combination of steel and cement-asbestos pipe. Transitions to steel were used where branches connect or where the pipe was run above ground. This pipe was initially installed because of the lower purchase and installation cost compared with steel (about 55\%). The pressure drop was also significantly less $(40 \%)$ than for steel pipe, thereby permitting use of smaller pipe. Initial installations were made in 1975. The pipe worked reasonably well when handling minor flows to ponds through single runs; however, when considered as part of a multiwell system, it greatly complicated design and operation because of restrictions due to pressure limits (150 psi) and thermal shocks.

The transite (cement-asbestos) piping was installed an average of 3.5 to $4.5 \mathrm{ft}$ underground but some sections were up to $15 \mathrm{ft}$ deep because of the contours of the terrain. The pipeline was assembled in 13-ft sections with a gasketed collar at each joint. The pipeline was insulated with 1 in. of polyurethane foam and covered with fine compacted soil. A total length of 6.12 miles of transite pipe was installed between wells. The pipe worked well with low-pressure loss during constant steadystate operations. However, the number of transite pipeline breaks over the years totaled 60 , which could be classified as pipe ruptures $(40 \%)$ and coupling/gasket leaks $(60 \%)$. The ruptures were thought to be the result of thermal shock, water hammer, and defective pipe. Leaks at the joints were caused by broken or rolled gaskets and shifting collars, some of which may have been due to thermal ratcheting. When breaks occurred, red stones and dirt washed into the pipe, causing filters to clog and sometimes high-pressure drops due to large rocks getting into the system and lodging at restrictions.

Upset conditions would travel through the systems causing multiple breaks. This was alleviated somewhat by separating the operation of the supply system from the injection system so that the supply system geofluid was dumped to a pond from which the injection system would draw fluid. This also reduced the number of people needed to man the operation from six to two people.

System Performance. The problems which developed during the initial field operation and heatup in the S\&I system with the production well pumps were corrected, and operation was relatively stable during steady-state operation of the plant. The production well pump problem was solved by an appropriately designed lubricated vertical line shaft pump. Some improvements, such as enlarging the lubricated bearing grooves and using a water-soluble lubricant that does not allow calcite buildup, would probably have increased the pump's useful lifetime.

The cement-asbestos piping remained installed during plant operation, and was found to be extremely susceptible to rupture. It is not recommended for use as piping for a binary power plant because of the transients which occur during normal operation. 


\section{CONCLUSIONS AND RECOMMENDATIONS}

Initially, the pilot plant was to be operated for five years. A substantial number of the objectives were concerned with determining the operating and performance history of the plant. Budgetary constraints forced a reduction in the operating period with a corresponding reduction in the scope of the objectives.

Within the reduced scope, the project was an overall success and the major objectives not requiring the long term tests were met. The construction, operation, and testing of the binary Rankine thermodynamic cycle power plant to produce electrical energy from a moderate-temperature geothermal resource indicated that the system is technically viable. The plant performance was generally as predicted, the startup was performed easily, and operation was smooth and required little operator intervention except for upsets and problems caused by the cooling water treatment systems.

Following are several of the more significant conclusions made after building, starting, testing, and operating the plant.

1. The plant, as a system, operated very smoothly at steady-state with no operator intervention.

2. The problems uncovered in the plant proper during operation and performance, with the exception of those associated with the cooling water treatment system, were minor in nature and would have been easily corrected by small changes in equipment or operating procedures had the plant been operated for a longer period of time. The problems which did occur were not generic in nature, but were specific to this plant.

3. The only transient that caused operational difficulty was the turbine trip. This could have been remedied with a small change in the control system.

4. When performance was assessed for the baseline operational mode, the plant produced $4.01 \mathrm{MW}(\mathrm{e})$, compared with the 5.35 MW(e) that had been predicted. Based on the analyses contained in this report, if additional plant testing had been allowed, the overall plant performance could have been improved and the predicted performance achieved relatively simply, by:

a. Decreasing boiler level to the point resulting in zero entrained liquid in the vapor outlet

b. Running cooling tower fans on higher speeds

c. Reinstalling or replacing cooling water pumps to give design cooling water flow

d. Adding a stage to the isobutane feed pump.

.5. In the supply and injection system, lineshaft production well pumps with lubricating line-shaft bearings worked well.

6. The transite piping that carried the geofluid from the production wells to the plant and afterward to the injection wells caused severe limitations on supply and injection system operability. A large number of pipe breaks resulted because of the extremely restrictive operating window imposed by the transite pipe.

7. The cooling water treatment system was quite complex. This complexity arose because of the use of geofluid as cooling water makeup in conjunction with the carbon steel condenser tubes. Other condenser tube material and more properly sized water treatment equipment would have resulted in operation that allowed more cycles of concentration in the cooling water and reduced the amounts of chemicals required.

The following recommendations are made as a result of the experience gained in starting up, operating, and testing the plant:

1. A binary plant is a technically viable type of plant for use in power production from a moderate-temperature geothermal resource. The dual-boiling characteristic 
of the plant caused no problems in plant operability and the performance was predictable.

2. Transite piping in a geofluid supply and injection system should not be considered. It creates too severe operational restrictions as compared to steel pipe.

3. Line-shaft production well pumps are recommended until more reliable submersible pumps are developed.

4. Geothermal fluid can be used for cooling water makeup if appropriate water treatment is performed. If geothermal fluid is to be used, however, carbon steel tubes should not be used in the condenser and if steel is used in other portions of the cooling system, those portions should be coated to prevent the dissolution of iron.

5. Sufficient capacity should be designed into the working fluid feed pumps and cooling water pumps, and their respective motors, to supply design flow with above design pressure drops in the system piping. These two flows are critical to achieving maximum performance from a binary plant.

6. Automatic controls on working fluid feed pumps should not trip the pump instantaneously on no flow. In a turbine trip condition, instantaneous trip of the working-fluid pumps will cause the entire system to shut down, and not permit proceeding in an orderly manner into the turbine bypass mode. A corrective measure may consist of designing the pump to operate with no flow for a period of 30 to $50 \mathrm{~s}$.

7. If kettle-type boilers are used, care should be taken to prevent entrained liquid from leaving the boilers both by putting separators in the vapor outlet lines and by operating at a relatively low liquid level in the boilers.

\section{REFERENCES}

1. C. J. Bliem, (ed.), "Plant Performance Assessment Test Plan for the 5-MW(e) Pilot Geothermal Power Plant," GP-145, EG\&G Idaho, January 1979.

2. C. J. Bliem, "Detailed Specifications for the Plant Performance Testing of the 5-MW(e) Pilot Geothermal Power Plant," PG-G-80-038, EG\&G Idaho, September 1980.

3. C. A. Meyer et al., 1967 ASME Steam Tables, New York, American Society of Mechanical Engineers, 1967.

4. K. E. Starling, Fluid Thermodynamic Properties of Light Petroleum Systems, Houston, Texas: Gulf Publishing Co., 1973, pp. 194-205.

5. J. F. Ely and H. J. H. Hanley, "A Computer Program for the Prediction of Viscosity and Thermal Conductivity in Hydrocarbon Mixtures," National Bureau of Standards Technical Note 1039, Boulder, Colorado, April 1981.

6. C. J. Bliem, "Design and Off-Design Operation of a Dual-Boiling Binary Geothermal Power Plant," AIChE Symposium Series, No. 199, Vol. 76, pp. 163-172.

7. D. J. Wiggins and C. J. Bliem, "Operational Upset Transients in a Dual-Boiling Binary Cycle Geothermal Power Plant," Transaction Geothermal Resource Council, Vol. 4, September 1980, pp. 537-540.

8. D. Q. Kern, Process Heat Transfer, Chapter 17, McGraw Hill Book Company, Inc., 1950.

9. M. Dolenc et al., Geoscience Case Study, EGG-2125, Vol. I and II, EG\&G Idaho, November 1981 . 


\section{Other Reports of Possible Interest on the Raft River Facility}

T. L. Thurow and L. S. Cahn, Final Environmental Report: INEL Geothermal Environmental Project, EGG-2215, Vol. 1, EG\&G Idaho, September 1982.

D. W. Allman et al., Raft River Monitor Well Potentiometers Head Responses at Water Quality as Related to the Conceptual Ground-Water Flow System, EGG-2215, Vol. II, EG\&G Idaho, September 1982.

P. F. Ellis, II, and M. F. Conover, Materials Selection Guidelines for Geothermal Energy Utilization Systems, DOE/RA/27 26-1, Radian Corporation, January 1981.

R. L. Miller Results of Short-Term Corrosion Evaluation Tests at Raft River, TREE-1176, EG\&G Idaho, October 1977.

D. F. Suciu and R. L. Miller, Removal of Silica from Raft River Geothermal Water, EGG-FM-5170, EG\&G Idaho, June 1980.

J. F. Whitbeck, E. G. DiBello, and L. F. Walrath, "Raft River 5MW Power Plant: A Small Binary Power Plant," Geothermal Resources Council 1982 Proceedings, June 1982.

D. F. Suciu and P. M. Wikoff, An Evaluation of Materials for Systems Using Cooled, Treated Geothermal or High Saline Brines, EGG-2213, EG\&G Idaho, September 1982. 


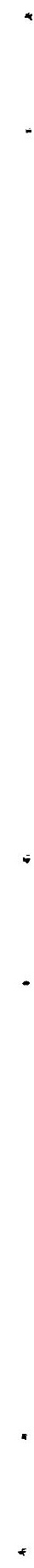


APPENDIX A

PLANT PIPING AND INSTRUMENTATION SCHEMATIC DRAWINGS 


\section{APPENDIX A \\ PLANT PIPING AND INSTRUMENTATION SCHEMATIC DRAWINGS}

This appendix contains the as-built piping and instrumentation schematics for the plant in the order listed below.

1. Isobutane System-Sheet 1

2. Isobutane System-Sheet 2

3. Isobutane System-Sheet 3

4. Isobutane System-Sheet 4

5. Geothermal Fluid System-Process Area
6. Cooling Water System

7. Water Treatment System

8. Instrument Air and Nitrogen System

9. Isobutane Flare System

10. Fire Mains and Hydrants

11. Graphic Control Panel. 


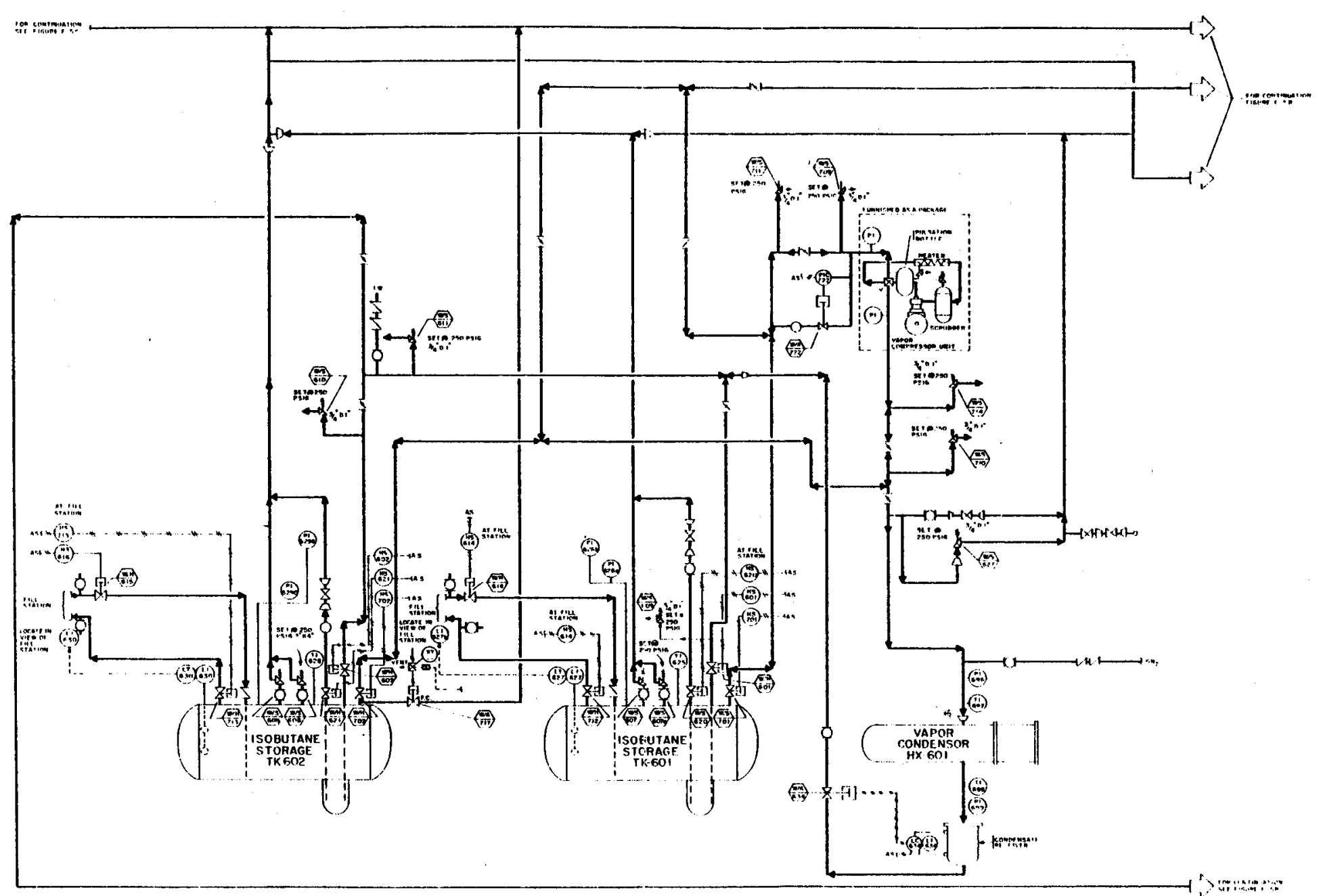

ISOBUTANE SYSTEM-Sheet 1 


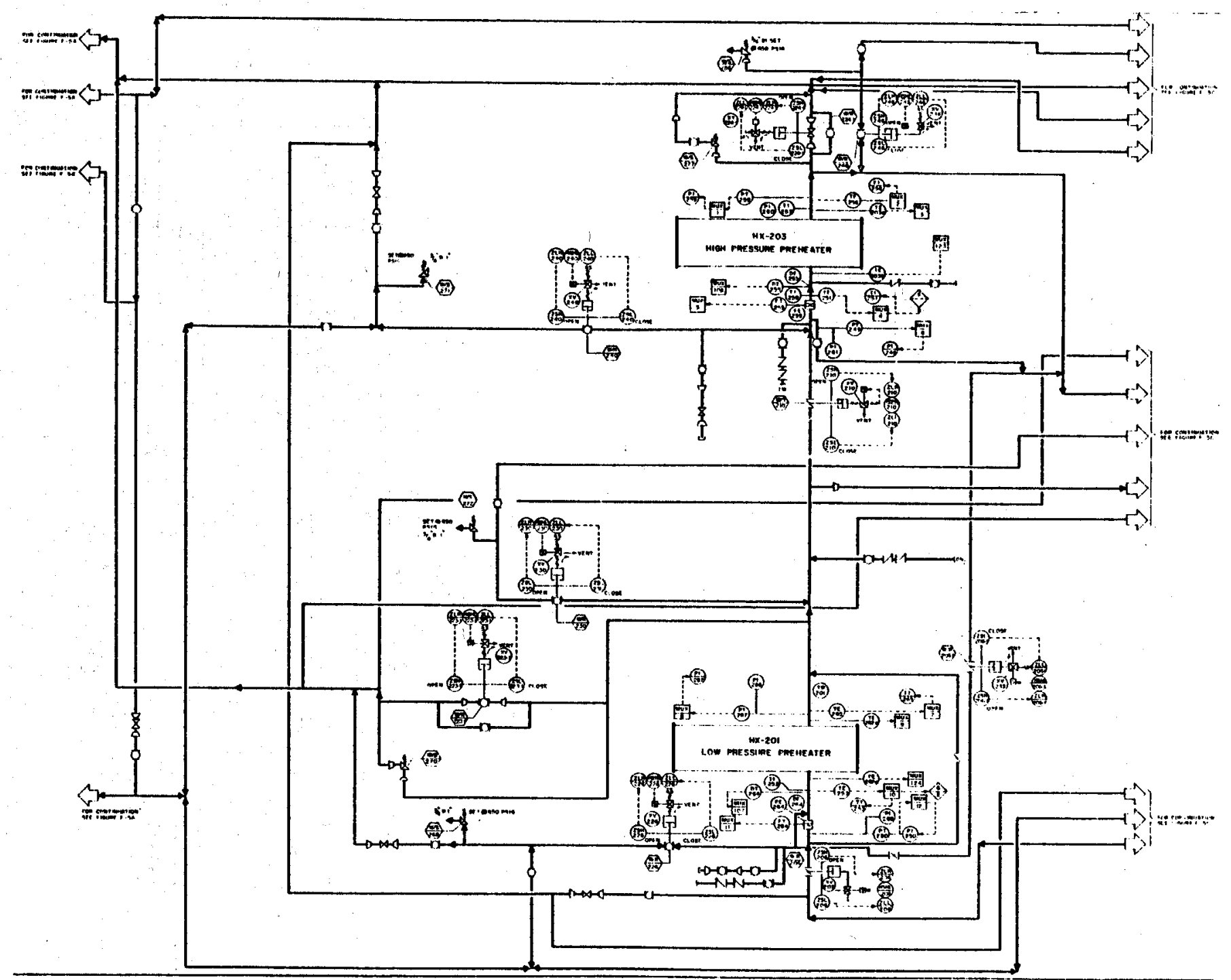

ISOBUTANE SYSTEM-Sheot 2 


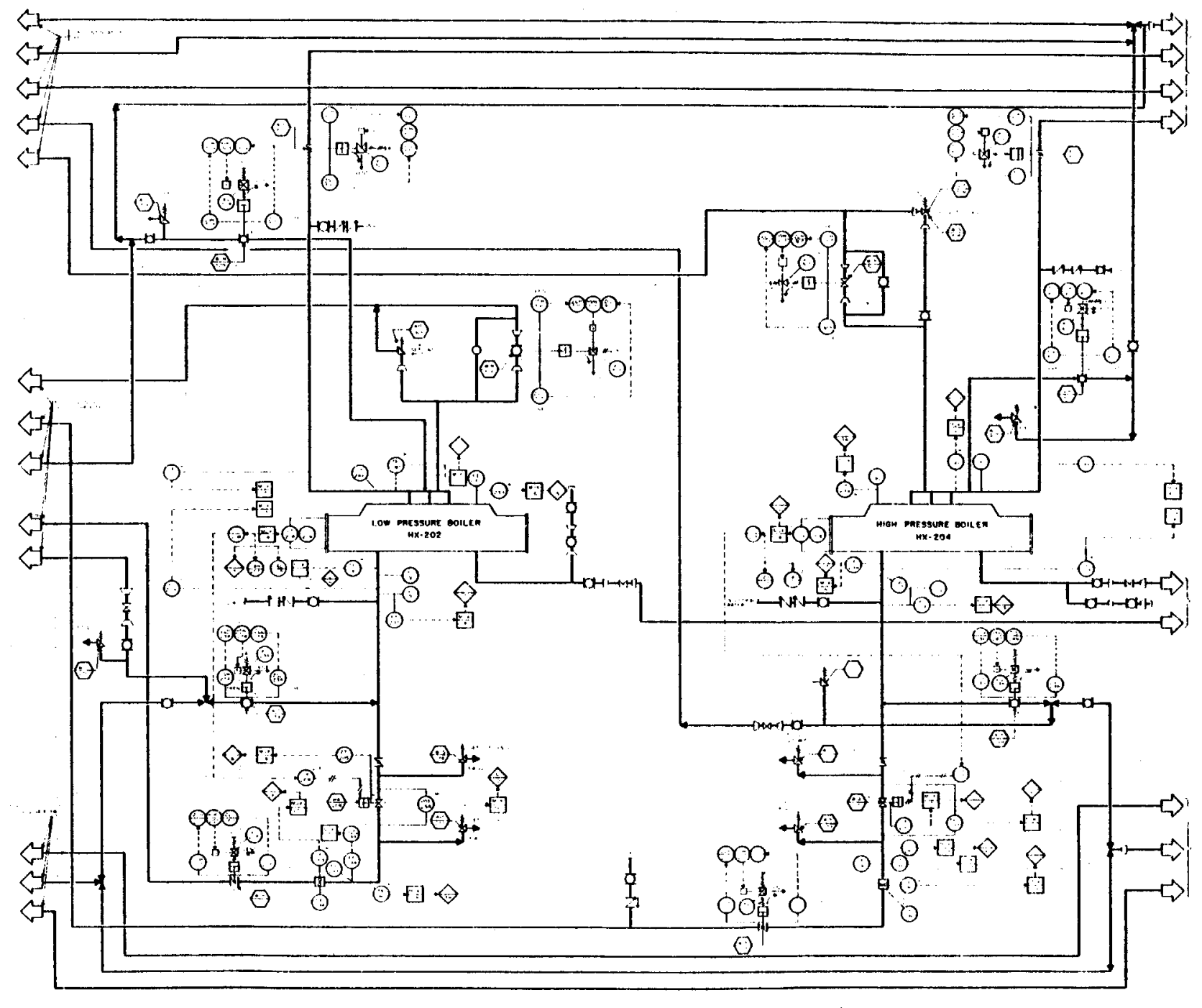

ISOBUTANE SYSTEM-Sheet 3 


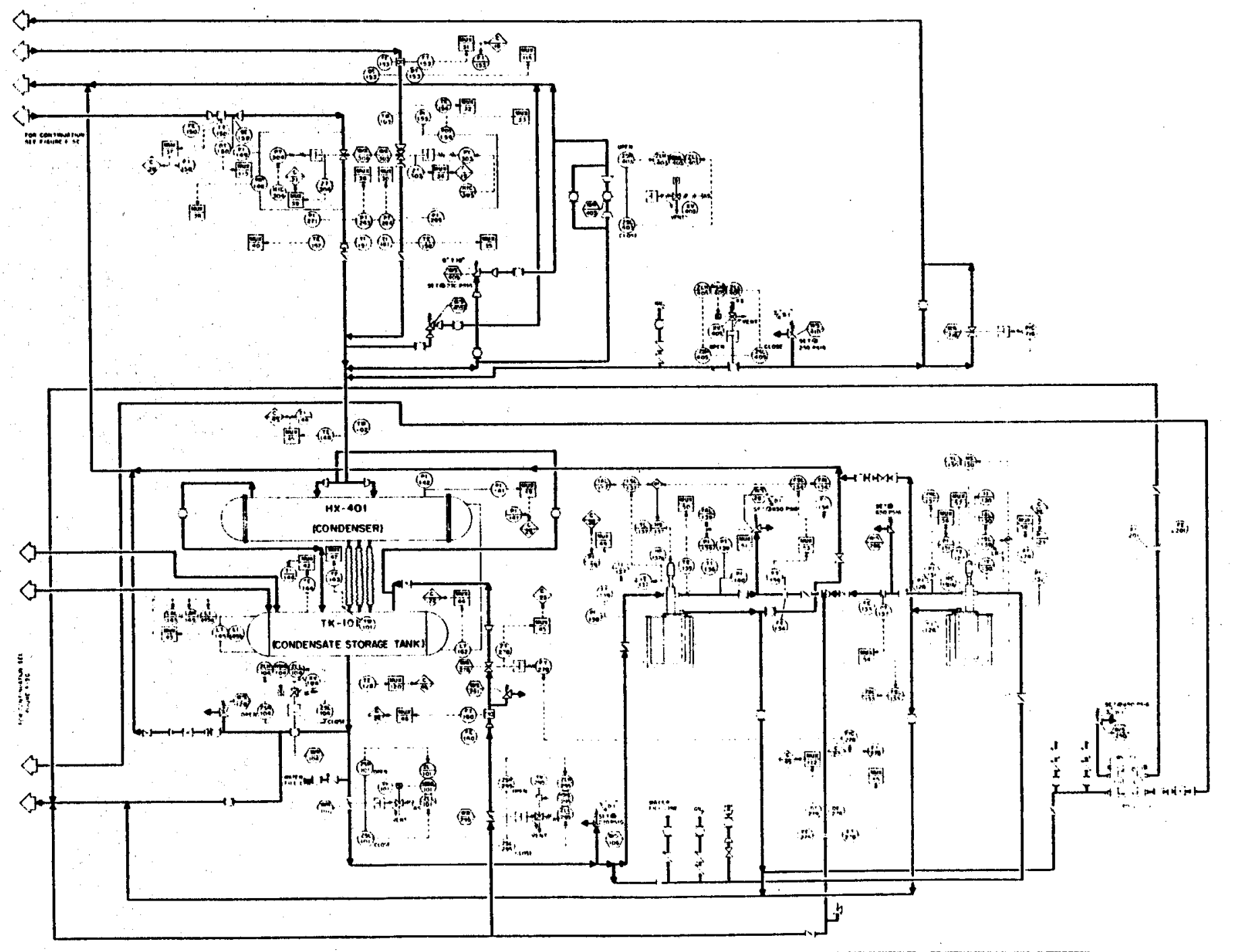

ISOBUTANE SYSTEM Shoel 4 


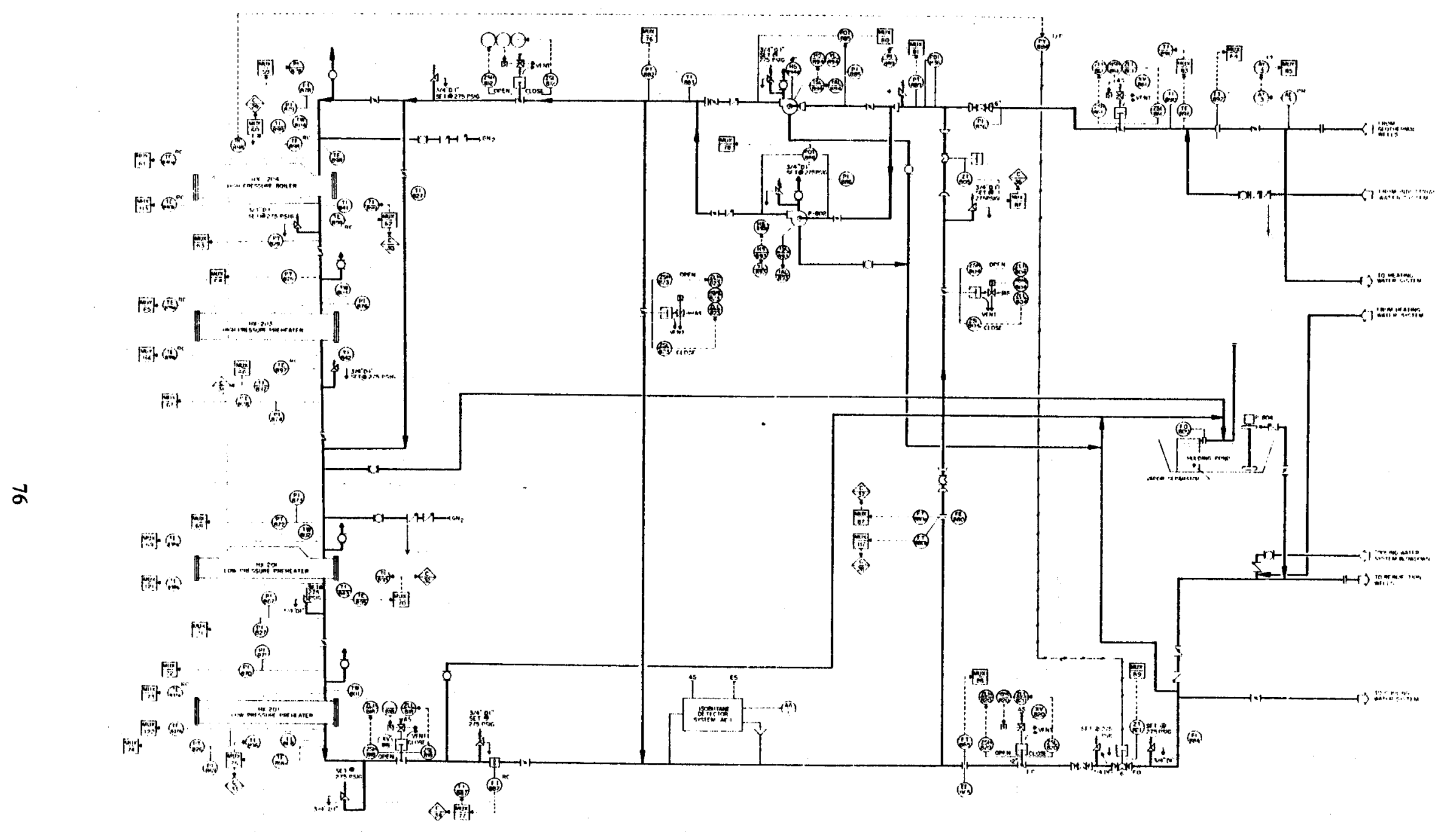

GEOTHERMAL FLUID SYSTEM-Process Area 


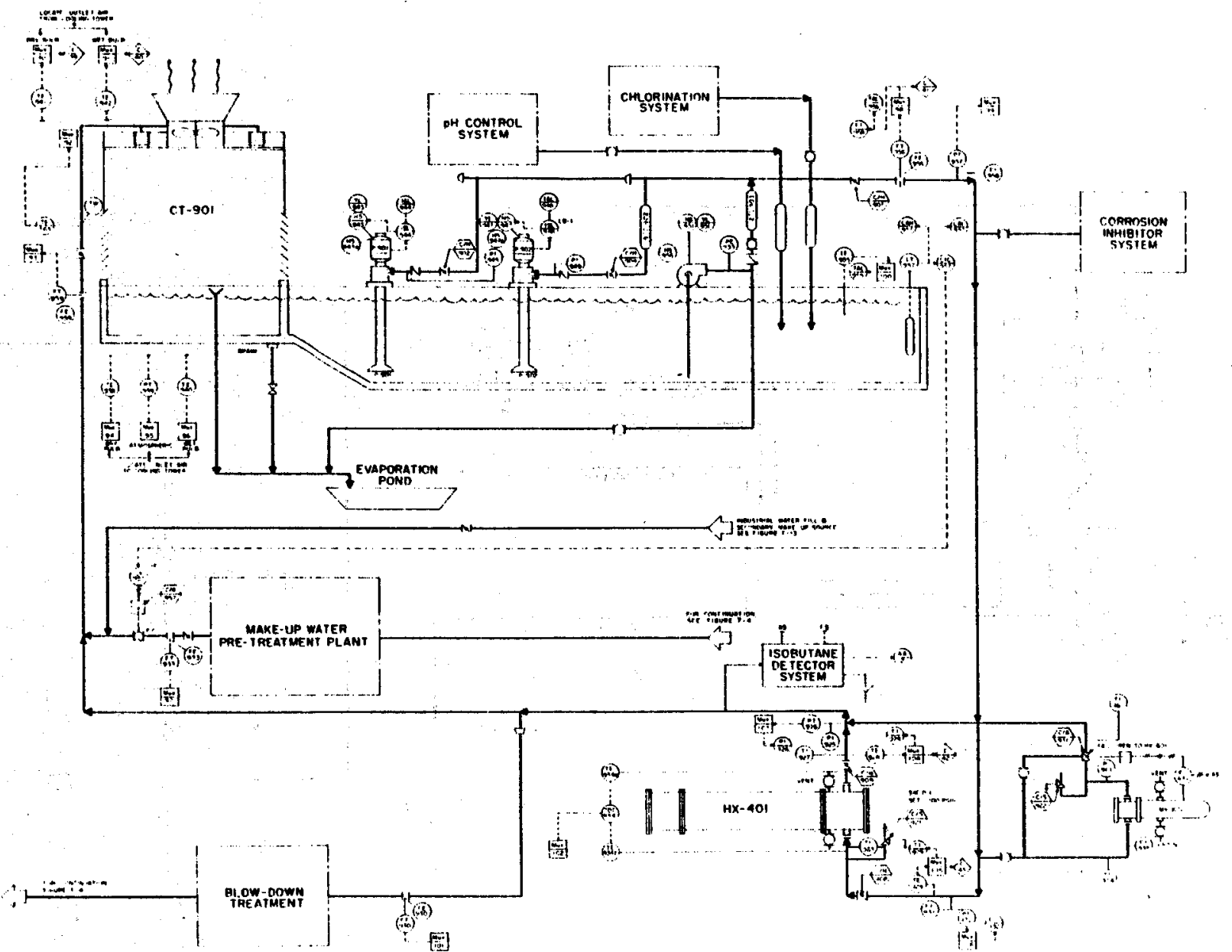




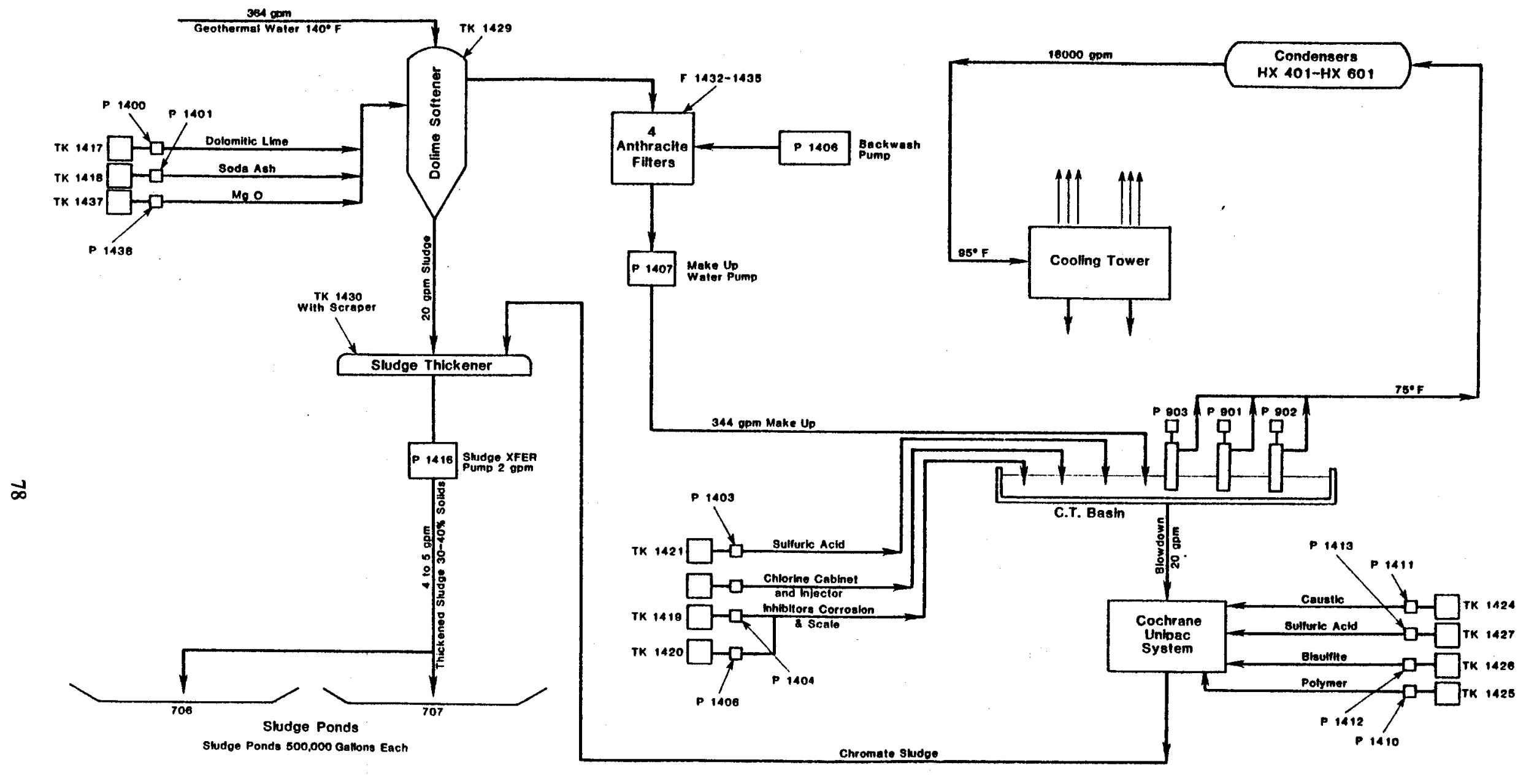

FIGURE F-14

WATER TAEATMENT

SYSTEM 


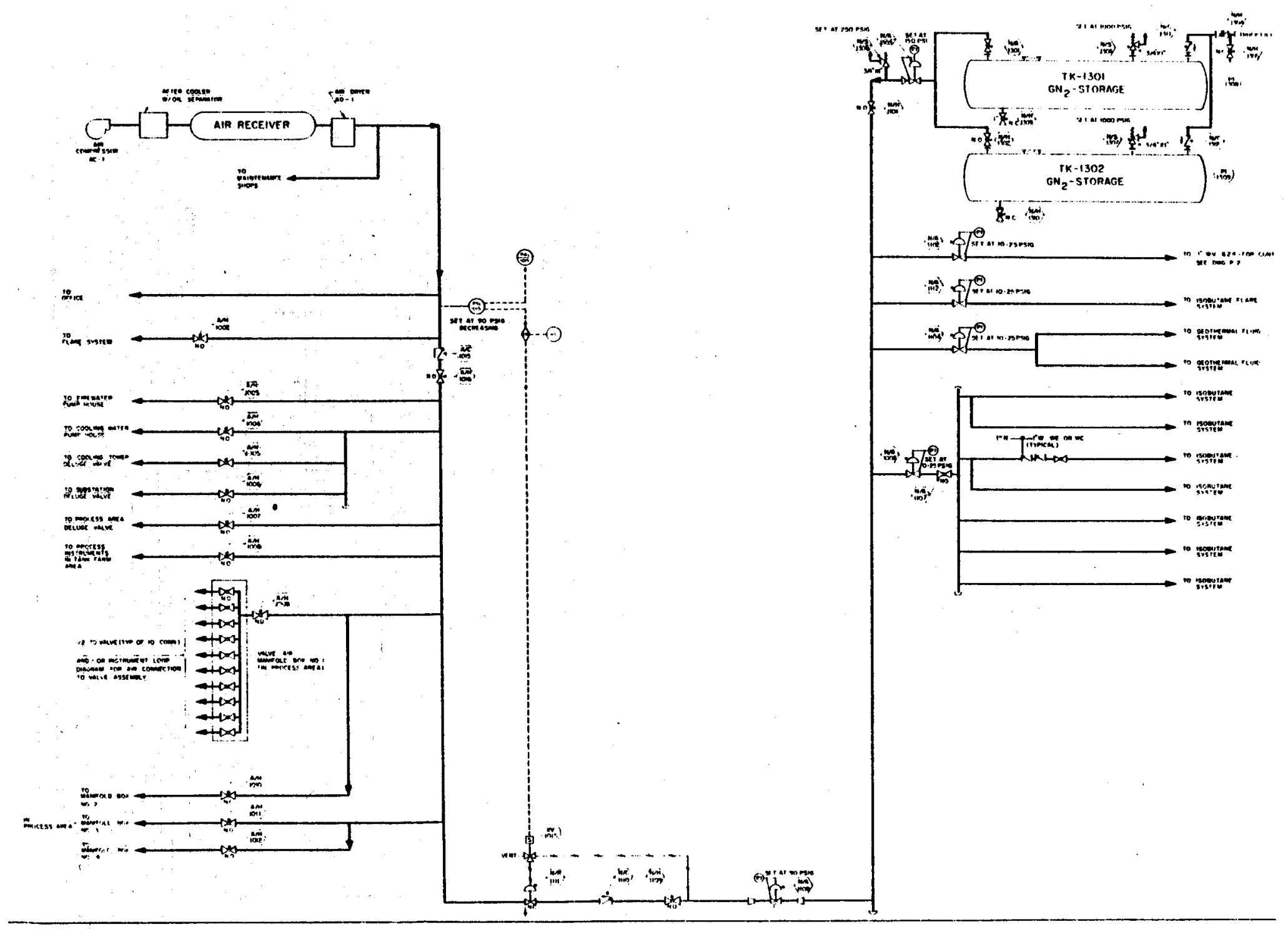

NSTRUMENT AIR AND NITROGEN SYSTEM 


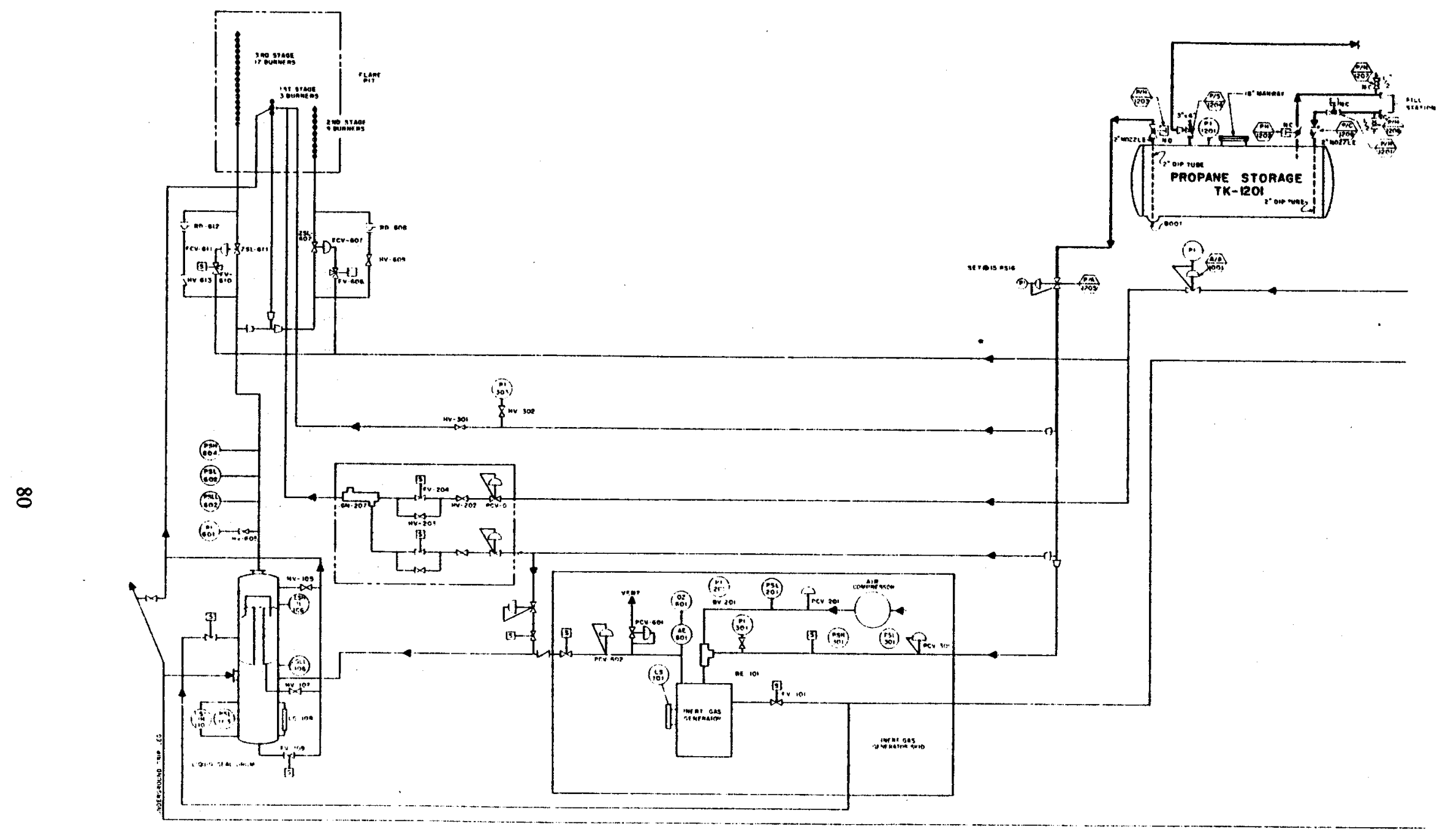

ISOBUTANE FLARE SYSTEM 


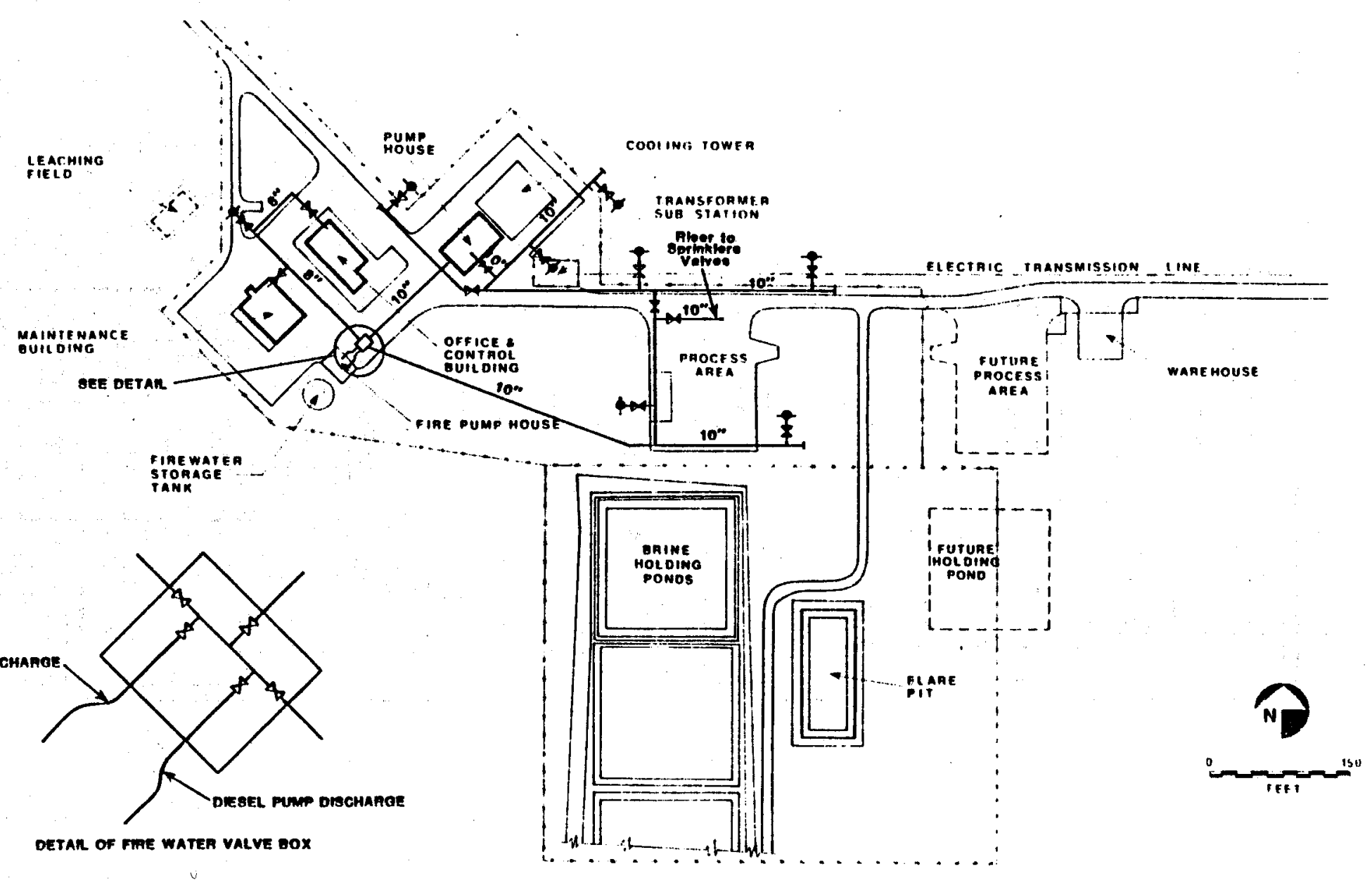




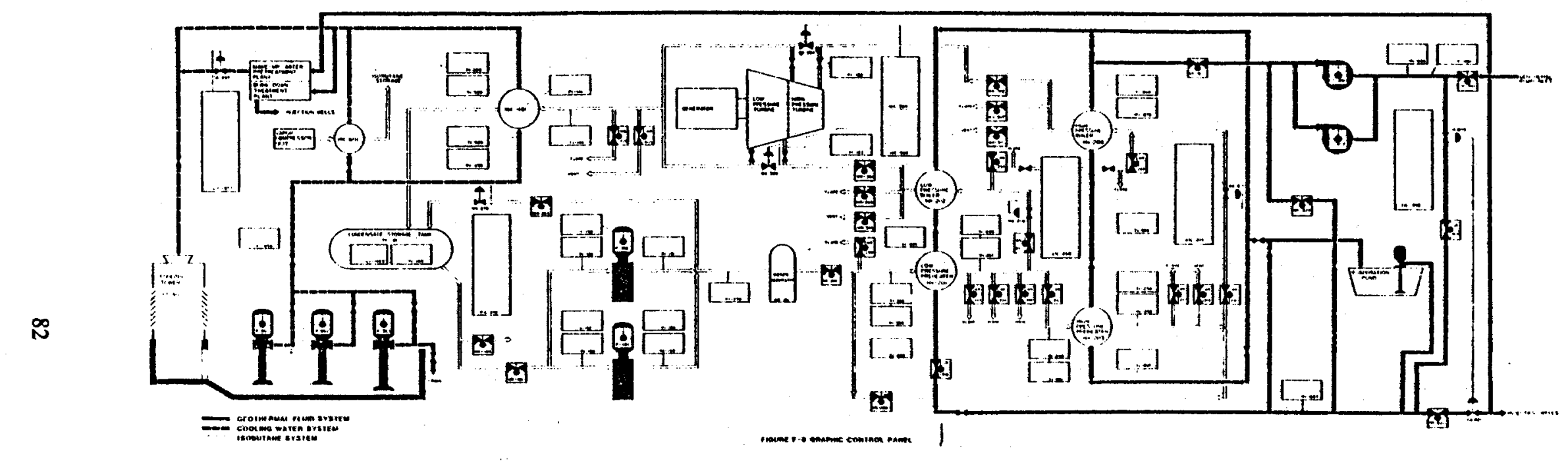

